ERNEST DRLANDI LAWRENCE BERKELEY NATIONAL LABDRATIRY

\title{
Site Environmental Report for 2007 Volume I
}

Environment, Health, and Safety Division

September 2008

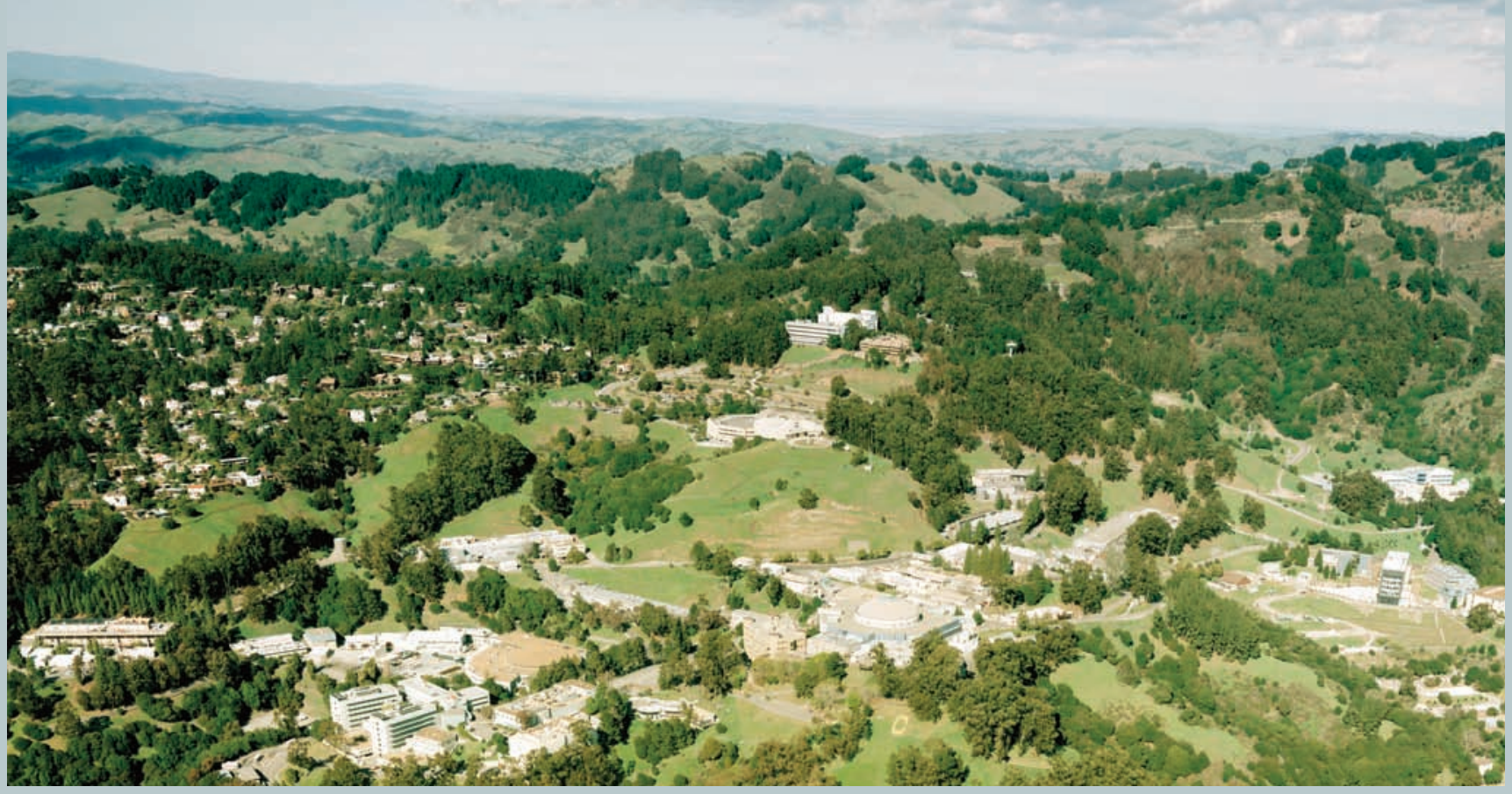




\section{DISCLAIMER}

This document was prepared as an account of work sponsored by the United States Government. While this document is believed to contain correct information, neither the United States Government nor any agency thereof, nor The Regents of the University of California, nor any of their employees, makes any warranty, express or implied, or assumes any legal responsibility for the accuracy, completeness, or usefulness of any information, apparatus, product, or process disclosed, or represents that its use would not infringe privately owned rights. Reference herein to any specific commercial product, process, or service by its trade name, trademark, manufacturer, or otherwise, does not necessarily constitute or imply its endorsement, recommendation, or favoring by the United States Government or any agency thereof, or The Regents of the University of California. The views and opinions of authors expressed herein do not necessarily state or reflect those of the United States Government or any agency thereof or The Regents of the University of California.

Ernest Orlando Lawrence Berkeley National Laboratory is an equal opportunity employer. 


\title{
Site Environmental Report for 2007
}

\author{
Volume 1
}

September 2008

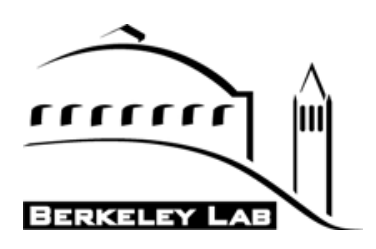





\section{Table of Contents}

\section{VOLUMEI}

Preface.

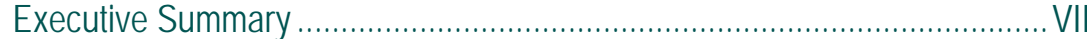

1 Introduction................................................................... 1-1

2 Performance-Based Environmental Management System.................. 2-1

3 Environmental Program Summary ................................................ 3-1

4 Environmental Monitoring......................................................... 4-1

5 Radiological Dose Assessment ...................................................... 5-1

6 Quality Assurance .................................................................... 6-1

Acronyms and Abbreviations ........................................................... AA-1

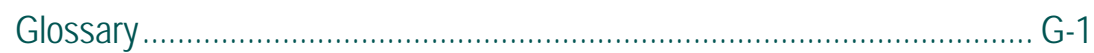

Volume I. Distribution List ..................................................................

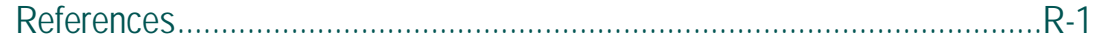

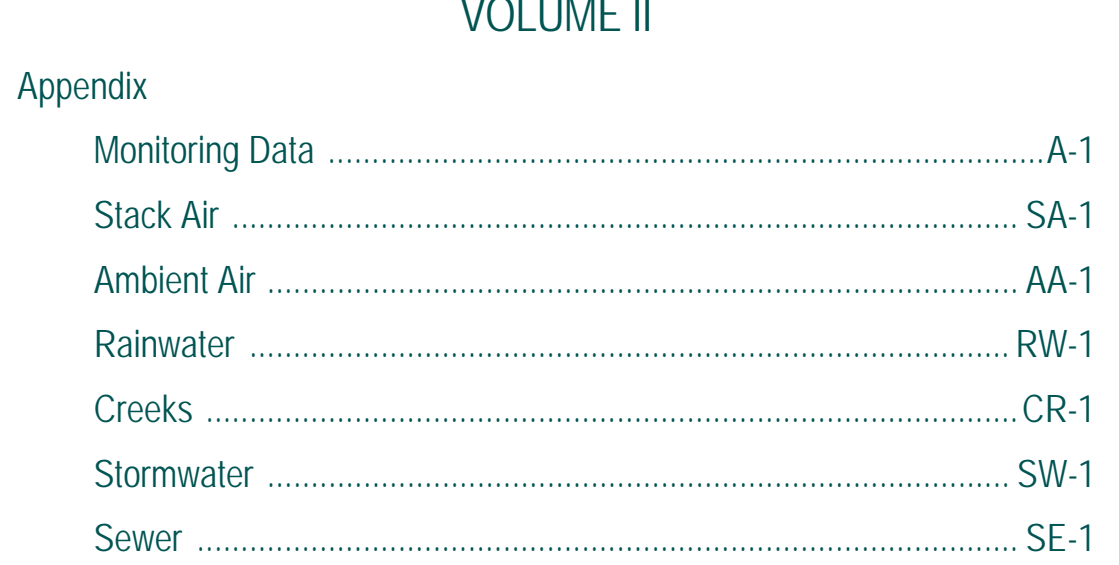


Fixed Treatment Units ....................................................... F-1

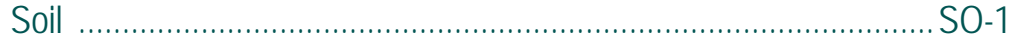

Sediment 


\section{Preface}

Each year, the University of California (UC) at Ernest Orlando Lawrence Berkeley National Laboratory, referred to variously throughout this report as "Berkeley Lab," "the Laboratory," "Lawrence Berkeley National Laboratory," and "LBNL," prepares an integrated report on its environmental programs to satisfy the requirements of United States Department of Energy Order 231.1A, Environment, Safety, and Health Reporting. ${ }^{1}$ The Site Environmental Report for 2007 summarizes Berkeley Lab’s environmental management performance, presents environmental monitoring results, and describes significant programs for calendar year 2007.

The report is separated into two volumes. Volume I is organized into an executive summary followed by six chapters that contain an overview of the Laboratory, a discussion of the Laboratory's environmental management system, the status of environmental programs, and summarized results from surveillance and monitoring activities. Volume II contains individual data results from surveillance and monitoring activities.

The Site Environmental Report is distributed by releasing it on the Web from the Berkeley Lab Environmental Services Group (ESG) home page, which is located at http://www.lbl.gov/ehs/esg/. Many of the documents cited in this report also are accessible from the ESG Web page. CD and printed copies of this Site Environmental Report are available upon request.

The report follows the Laboratory's policy of using the International System of Units (SI), also known as the metric system of measurements. Whenever possible, results are also reported using the more conventional (non-SI) system of measurements, because the non-SI system is referenced by several current regulatory standards and is more familiar to some readers. Two tables are provided at the end of the Glossary to help readers: Table G-1 defines the 
prefixes used with SI units of measurement, and Table G-2 provides conversions to non-SI units. Years mentioned in this report refer to calendar years unless specified as fiscal year(s).

Readers are encouraged to comment on this report by completing the survey form in the Web version of the report. This report was prepared under the direction of Ron Pauer of ESG. Please address any questions regarding this report to him by telephone at 510-486-7614, or by e-mail at ropauer@1bl.gov. The primary contributors are David Baskin, Robert Fox, John Jelinski, Ginny Lackner, Ron Pauer, Patrick Thorson, Linnea Wahl and Steve Wyrick (Volume II). 


\section{Executive Summary}

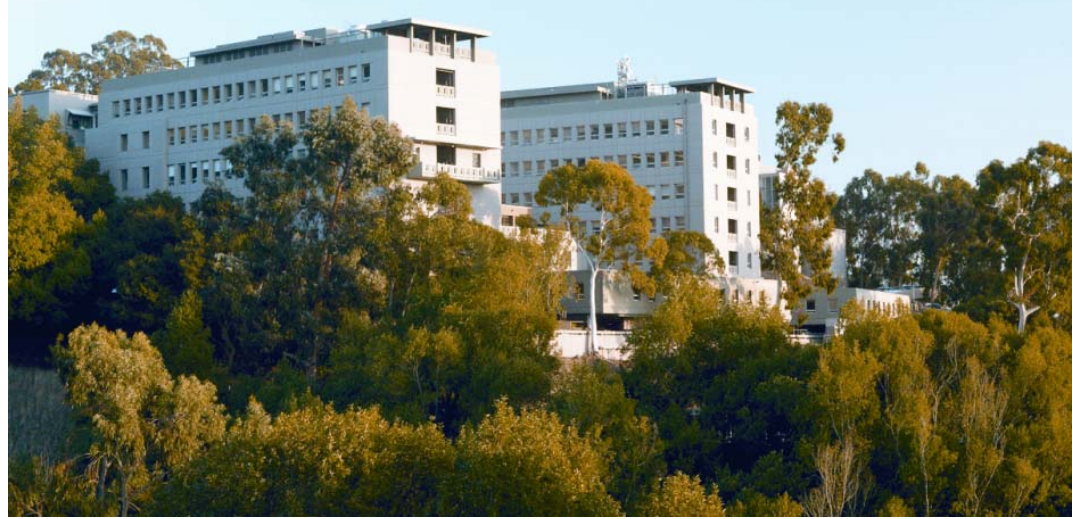

Building 50 Complex

The University of California at Ernest Orlando Lawrence Berkeley National Laboratory is a multiprogram scientific facility operated by the UC for the United States Department of Energy (DOE). The Laboratory's research is directed toward the physical, biological, environmental, and computational sciences, in order to deliver the scientific knowledge and discoveries pertinent to DOE's missions.

This annual Site Environmental Report covers activities conducted in calendar year (CY) 2007. The format and content of this report satisfy the requirements of DOE Order 231.1A, Environment, Safety, and Health Reporting, ${ }^{1}$ and the operating contract between UC and DOE. ${ }^{2}$ 


\section{INTEGRATED SAFETY MANAGEMENT AND ENVIRONMENTAL MANAGEMENT SYSTEMS}

Berkeley Lab employs Integrated Safety Management (ISM), which is a DOE management system that applies the following core Environment, Health, and Safety functions to all Laboratory work:

1. Work planning

2. Hazard and risk analysis

3. Establishment of controls

4. Work performance in accordance with the controls

5. Feedback and improvement

Laboratory activities are planned and conducted with full regard to protecting employees, the public, and the environment and complying with all applicable environmental laws and regulations.

In 2007, Berkeley Lab continued to implement a performance-based Environmental Management System (EMS), which is integrated with the Laboratory's ISM System. When practical, the existing processes used for ISM were used to support and implement environmental performance improvement and compliance management. New processes were developed to support the EMS where needed. For more information, see Chapter 2.

\section{OPERATING PERMITS, INSPECTIONS, AND INCIDENTS IN 2007}

- At the end of the year, Berkeley Lab held 45 environmental operating permits from various regulatory agencies for air and water quality protection and hazardous waste handling.

- Twenty-five inspections of Berkeley Lab's environmental programs occurred during the year. Eleven violations were received and all were reported under the DOE occurrence-reporting program ${ }^{3}$ which is used to track incidents across the DOE complex. Two additional environmental occurrences, for which no violations were issued, were reported under the DOE occurrence reporting program.

- In March 2007, Berkeley Lab received the final report from the California Department of Toxic Substances Control (DTSC) 2006 inspection of the Hazardous Waste Handling Facility (HWHF), citing two Class II violations. Both violations cited a discrepancy between the accumulation start date on a hazardous waste container and the accumulation start date for the container in the operating record.

- In March 2007 DTSC and Berkeley Lab entered into a consent order regarding hazardous waste violations found in inspections between 2003 and 2005. These violations were discussed in previous Site Environmental Reports. Specifically, the Laboratory agreed to pay a penalty of $\$ 28,000$ for accepting hazardous waste from off-site, in this case from Building 903, and transporting hazardous materials to the 903 warehouse, which is not authorized to accept hazardous waste. The Laboratory also held hazardous waste in a Satellite Accumulation Area for more than one year, which is a California Health and Safety Code violation. Berkeley Lab corrected the violations at the time they were issued and continues to work to prevent additional instances. DTSC has acknowledged that all terms and conditions of the consent order were met.

- In June 2007 there were two occurrences when wastewater from the sanitary sewer system overflowed from sewer manholes. One was in the Building 75 area and the other was in the Building 90 area. Environmental regulations required reporting both releases to the California Office of Emergency Services, the Regional Water Quality Control Board, and the City of Berkeley. 
- In June 2007, Berkeley Lab received seven notices of violation from the California Department of Public Health (DPH), Medical Waste Management Program, for minor storage and labeling issues. One violation was contested. Note that DPH was formerly the Department of Health Services (DHS), and is referred to throughout this document as DPH.

- In October 2007, the City of Berkeley cited Berkeley Lab for two violations of the State of California's Permit-By-Rule Tiered Permit requirements. One involved labeling at the Building 77 wastewater treatment unit and the other was in regard to performing inspections at the Building 25 unit.

For additional information on operating permits, inspections, and incidents, see Chapter 3.

\section{PERFORMANCE EVALUATION}

Each year, UC and DOE perform an assessment of Berkeley Lab's environmental program, using measures developed jointly by Berkeley Lab, UC, and DOE. For fiscal year (FY) 2007 (October 1, 2006 to September 30, 2007), there were two environmental measures.

Berkeley Lab achieved a B + rating for the environmental protection measure. The score for this measure is based on environmental incidents. In FY 07 four incidents were recorded. All were minor issues resulting from a sewer system overflow, two inspections conducted by the State of California, DTSC, and one inspection by the DPH.

Berkeley Lab achieved an A rating for the second measure, the meeting of all EMS process milestones and the number of completed EMS projects.

For more information on environmental performance measures, go to Berkeley Lab's Office of Institutional Assurance home page at http://www.lbl.gov/DIR/OIA/OCA/contract-performance/index.html.

\section{ENVIRONMENTAL MONITORING AND DOSE ASSESSMENT}

Berkeley Lab's environmental monitoring program serves several purposes:

- To demonstrate that Laboratory activities operate within regulatory and DOE requirements

- To provide a historical record of Laboratory impacts on the environment

- To support environmental management decisions

- To provide information on the effectiveness of emission control programs

- To assess the maximum potential radiological dose to members of the public

To assess potential doses to the public resulting from Laboratory operations, three types of environmental radiation are measured:

1. Penetrating radiation (gamma and neutron) from sources such as accelerators

2. Emissions of dispersible radionuclides to stack air and sanitary sewer water from Laboratory activities

3. Concentrations of radionuclides in the ambient environment (air, surface water, vegetation, soil, sediment, and groundwater)

In 2007, the maximum dose to a member of the public from penetrating radiation was below detection limits and indistinguishable from the average United States background level, 3.6 millisieverts (mSv) (360 millirem [mrem]). ${ }^{4}$ The estimated maximum potential dose from all airborne radionuclides released from the Laboratory in 2007 was $1.2 \times 10^{-4} \mathrm{mSv}(0.012$ mrem). This is approximately $0.1 \%$ of the United States Environmental Protection Agency dose limit for dispersible radionuclide emissions $(0.10 \mathrm{mSv}$ $[10 \mathrm{mrem}]){ }^{5}$ 
Berkeley Lab also estimates the cumulative dose impact (population dose) from its dispersible radionuclide emissions to the entire population found within an 80-kilometer $(\mathrm{km})$ (50-mile) radius of Berkeley Lab. This measure is the sum of all individual doses to the population residing or working within this radius. The population dose for 2007 from dispersible radionuclide emissions was estimated at $3.1 \times 10^{-3}$ person-sievert (person-Sv) $(0.31$ personrem). From natural background radionuclides alone, this same population receives an estimated dose of 12,000 person-Sv (1,200,000 person-rem). No regulatory standard exists for this measure.

During the year, ambient air, creek water, groundwater, sediment, soil, stormwater, and wastewater were monitored for radiological and nonradiological constituents to comply with operational permits and DOE requirements. Results were below or near analytical detection limits, or within urban background levels and below regulatory limits.

Berkeley Lab is currently in the Corrective Measures Implementation (CMI) phase of the Resource Conservation and Recovery Act (RCRA) Corrective Action Program (CAP). Investigations and monitoring conducted since the early 1990s have characterized nine principal groundwater contamination plumes, all of which are on-site and do not involve groundwater used as a source of public drinking water. The purpose of the CMI phase is to design, construct, operate, maintain, and monitor the corrective measures (clean-up activities) approved by the DTSC for cleanup of the contamination. Groundwater monitoring data indicate that the corrective measures implemented by LBNL have been effective in reducing concentrations of contaminants in the groundwater, the groundwater plumes are stable or attenuating, and contaminants are not migrating offsite in the groundwater.

For more details on environmental monitoring conducted in 2007, see Chapter 4. 


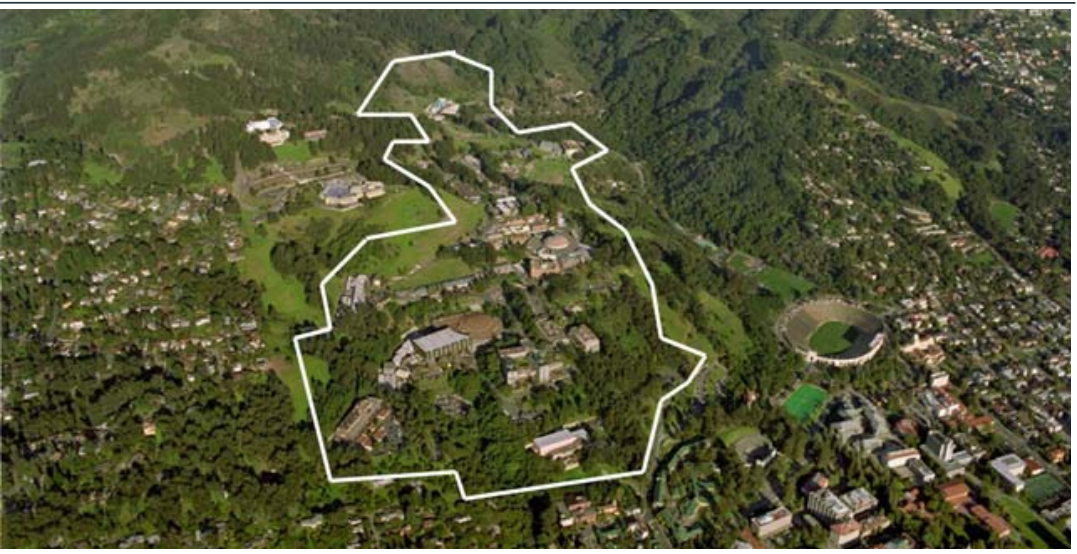

Lawrence Berkeley National Laboratory (outlined) is located east of the University of California Berkeley campus

$11-$ HSTORY

LABORATORY SITEDESCRIPTIONAND

EMMONMENTALSETTING

121 Location

1.2.2 Population and Space Distribution

1.2.3 Water Supply

1.2.4 Meteorology

1.2.5 Vegetation

1.2.6 Widlife

12.6.1 Protected Habitats

1.2.7 Geology and Hydrogeology

1.2.7.1 Soils 


\subsection{HISTORY}

Lawrence Berkeley National Laboratory was founded by Ernest O. Lawrence in 1931. Lawrence received the 1939 Nobel Prize in physics for his invention of the cyclotron (particle accelerator); and he is generally credited with the modern concept of interdisciplinary science, in which scientists, engineers, and technicians from different fields work together on complex scientific projects addressing national needs and programs. Lawrence's pioneering work established a great tradition of scientific inquiry and discovery at the Laboratory. Eleven Nobelists have been associated with the Laboratory. Eighty-one of its current researchers are members of the National Academies, ${ }^{1}$ which forms committees to advise the federal government and public.

The Laboratory supports work in such diverse fields as genomics, physical biosciences, nanoscience, life sciences, fundamental physics, accelerator physics and engineering, energy conservation technology, and materials science. Through its fundamental research in these fields, Berkeley Lab has achieved international recognition for its leadership and has made numerous contributions to national programs. Berkeley Lab's research embraces the following concepts to align with the United States Department of Energy (DOE) mission:

- Explore the complexity of energy and matter

- Advance the science needed to attain abundant clean energy

- Understand energy impacts on our living planet

- Provide extraordinary tools for multidisciplinary research

Since its beginning, Berkeley Lab has been managed by UC. Numerous Berkeley Lab scientists are faculty members on the campuses of either UC Berkeley or UC San Francisco. They and other Berkeley Lab researchers guide the work of graduate students pursuing advanced degrees through research at the Laboratory. High school students and teachers, as well as college and graduate students, participate in many Berkeley Lab programs designed to enhance science education, which is part of the Laboratory mission.

\subsection{LABORATORY SITE DESCRIPTION AND ENVIRONMENTAL SETTING}

Sections 1.2.1 through 1.2.3 describe the physical location, population, space distribution, and water supply at Berkeley Lab. Sections 1.2.4 through 1.2.7 describe the Laboratory site's meteorology, vegetation, wildlife, geology, and hydrogeology.

\subsubsection{Location}

Berkeley Lab is located about 5 kilometers $(\mathrm{km})$ (3 miles [mi]) east of San Francisco Bay (see Figure 1-1) on land owned by the University of California. The Laboratory's main site is situated on approximately 82 hectares (202 acres) of this land. UC provides long-term land leases to the DOE for the buildings at the Laboratory.

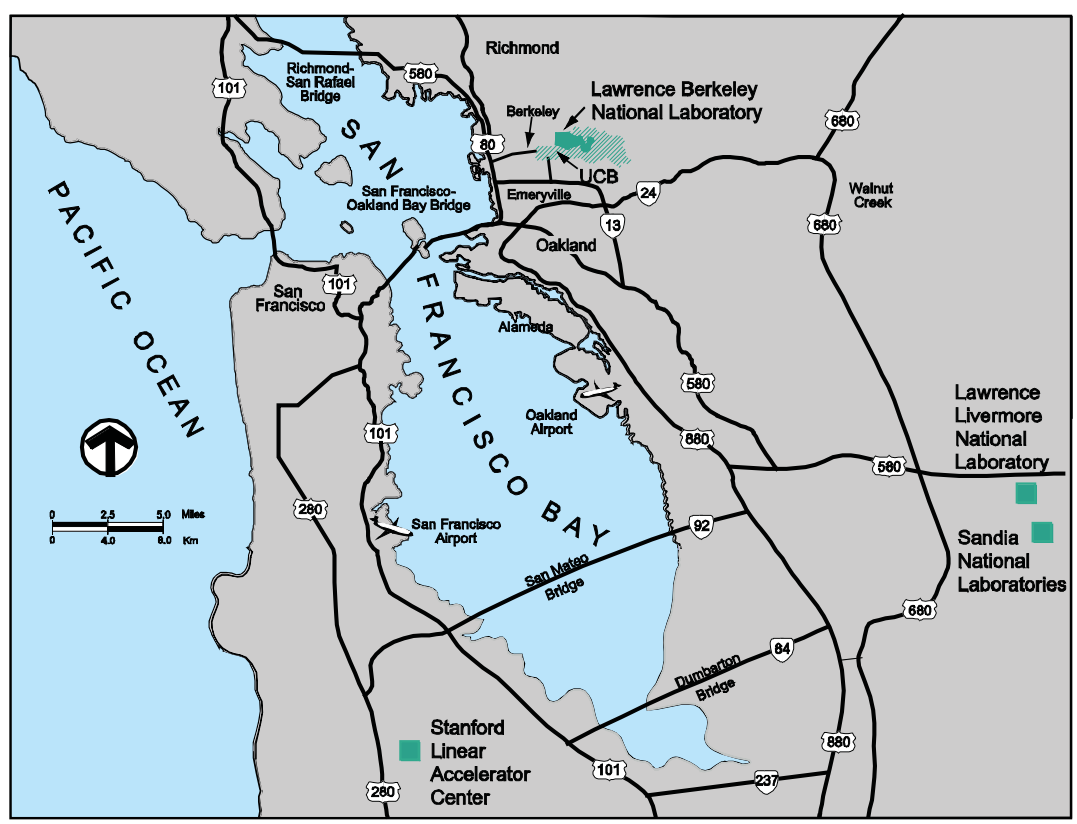

Figure 1-1 San Francisco Bay Area Map 
The main site lies in the hills above the UC Berkeley campus, on the ridges and draws of Blackberry Canyon (which forms much of the western part of the site) and adjacent Strawberry Canyon (which forms the eastern part of the site). Elevations across the site range from 135 to 350 meters (m) (450 to 1,150 feet [ft]) above sea level. The western portion of the site is in Berkeley, with the eastern portion in Oakland; the entire site is located within Alameda County. The population of Berkeley is estimated at approximately 103,000, and that of Oakland at 400,000.2

Adjacent land use consists of residential, institutional, and recreational areas (see Figure 1-2). The area to the south and east of the Laboratory, which is University land, is maintained largely in a natural or undeveloped state but includes UC Berkeley's Strawberry Canyon Recreational Area and Botanical Garden. Northeast of the Laboratory are the University's Lawrence Hall of Science, Space Sciences Laboratory, and Mathematical Sciences Research Institute. Berkeley Lab is bordered on the north by a residential neighborhood

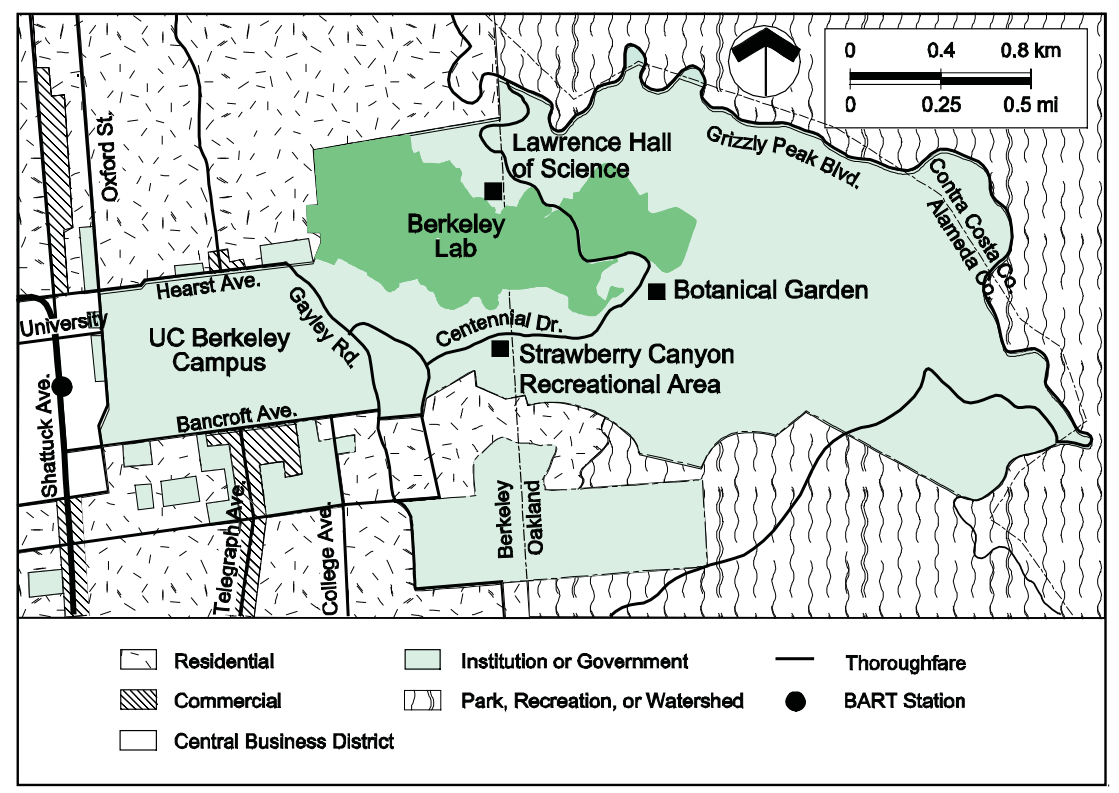

Figure 1-2 Adjacent Land Use of low-density, single-family homes and on the west by the UC Berkeley campus, as well as by multi-unit dwellings, student residence halls, and private homes. The area to the west of Berkeley Lab is highly urbanized.

\subsubsection{Population and Space Distribution}

Approximately 3,100 scientists and support personnel, plus 1,000 faculty and students work at Berkeley Lab. In addition, the Laboratory hosts over 6,000 participating guests each year, who use its unique scientific facilities for varying lengths of time. Berkeley Lab also supports 300 scientists and staff at off-site locations, including Walnut Creek, Oakland, Berkeley, Emeryville, and Washington, D.C. Approximately 800 of the Laboratory's scientists are jointly affiliated with multiple university campuses.

Berkeley Lab research and support activities are conducted in structures having a total area of 217,000 gross square meters (gsm) (2.33 million gross square feet [gsf]). About $77 \%$ of the total space is at the main site, about $4 \%$ is on the UC Berkeley campus (e.g., Donner Laboratory), and the remaining $19 \%$ is located in the various other off-site leased buildings. Figure 1-3 shows the Berkeley Lab space distribution. ${ }^{3}$

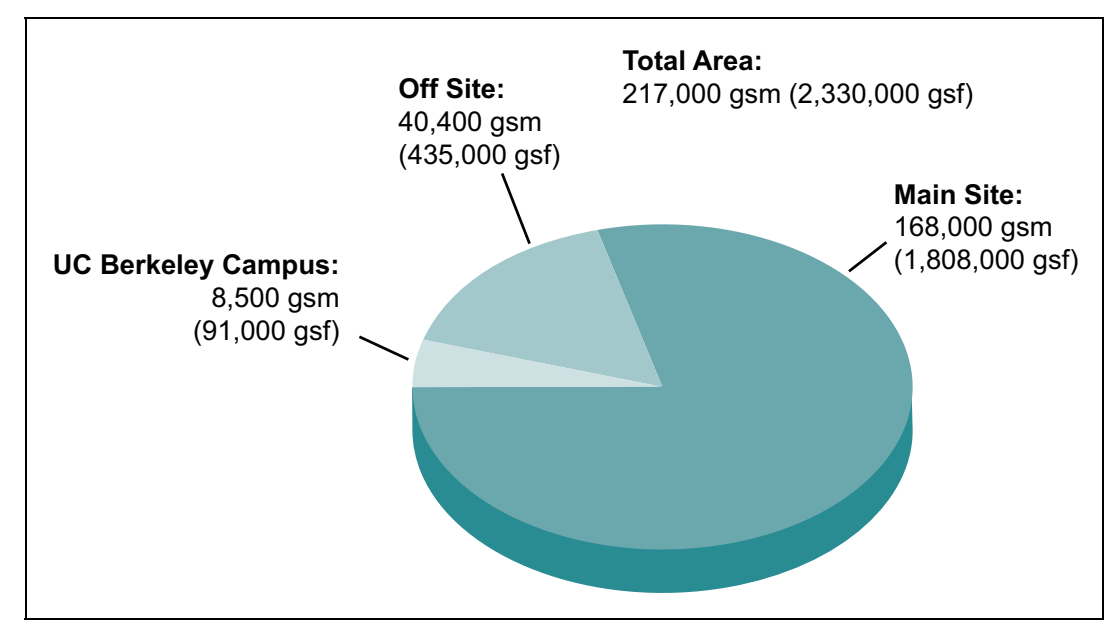

Figure 1-3 Space Distribution 


\subsubsection{Water Supply}

All domestic water for the Laboratory's main site is supplied by the East Bay Municipal Utility District (EBMUD). The site has no drinking-water wells. The domestic water originates in Sierra Nevada watershed lands and is transported to the Bay Area and ultimately to Berkeley Lab through a system of lakes, aqueducts, treatment plants, and pumping stations. EBMUD tests the water for contaminants and treats it to meet disinfection standards required by the Safe Drinking Water Act. ${ }^{4}$

Water use reductions of 16 percent from 2007 levels are planned by October 2015 in response to Executive Order 13423, Strengthening Federal Environmental, Energy, and Transportation Management, signed by the President on January 26, 2007.5

\subsubsection{Meteorology}

The climate of the site is temperate, influenced by the moderating effects of nearby San Francisco Bay and the Pacific Ocean to the west, and on the east by the East Bay hills paralleling the eastern shore of this same bay. These physical barriers contribute significantly to the relatively warm, wet winters and cool, dry summers of the site. The average annual temperature at the site is about $13^{\circ}$ Celsius (C) $\left(55^{\circ}\right.$ Fahrenheit $\left.[\mathrm{F}]\right)$. More than $90 \%$ of the time the temperature is in the range of $5^{\circ}$ to $20^{\circ} \mathrm{C}\left(41^{\circ}\right.$ to $\left.68^{\circ} \mathrm{F}\right)$. Seldom does the maximum temperature exceed $32^{\circ} \mathrm{C}\left(90^{\circ} \mathrm{F}\right)$ or the minimum temperature drop below $0^{\circ} \mathrm{C}\left(32^{\circ} \mathrm{F}\right)$.

The average annual precipitation, based on more than 30 years of Berkeley Lab records, is greater than 78 centimeters (cm) (nearly 31 inches [in]) of rain for the season (October 1 to September 30). Measurable snow does not fall at Berkeley Lab. About 95\% of the annual rainfall occurs between October and April; typically the wettest of these months are December through February. The 2006/2007 rainfall season closed with about $49.75 \mathrm{~cm}$ (19.5 in) of precipitation, or about two-thirds the normal amount.
On-site wind patterns change little from one year to the next. Figure 1-4, a graphical summary of the annual wind patterns called a "wind rose," illustrates the frequency of the predominant wind patterns. The most prevalent wind pattern occurs during fair weather, with daytime westerly winds blowing off the bay, followed by lighter nighttime southeasterly drainage winds of the East Bay hills. The other predominant wind pattern is associated with storm systems passing through the region, which usually occur during the winter

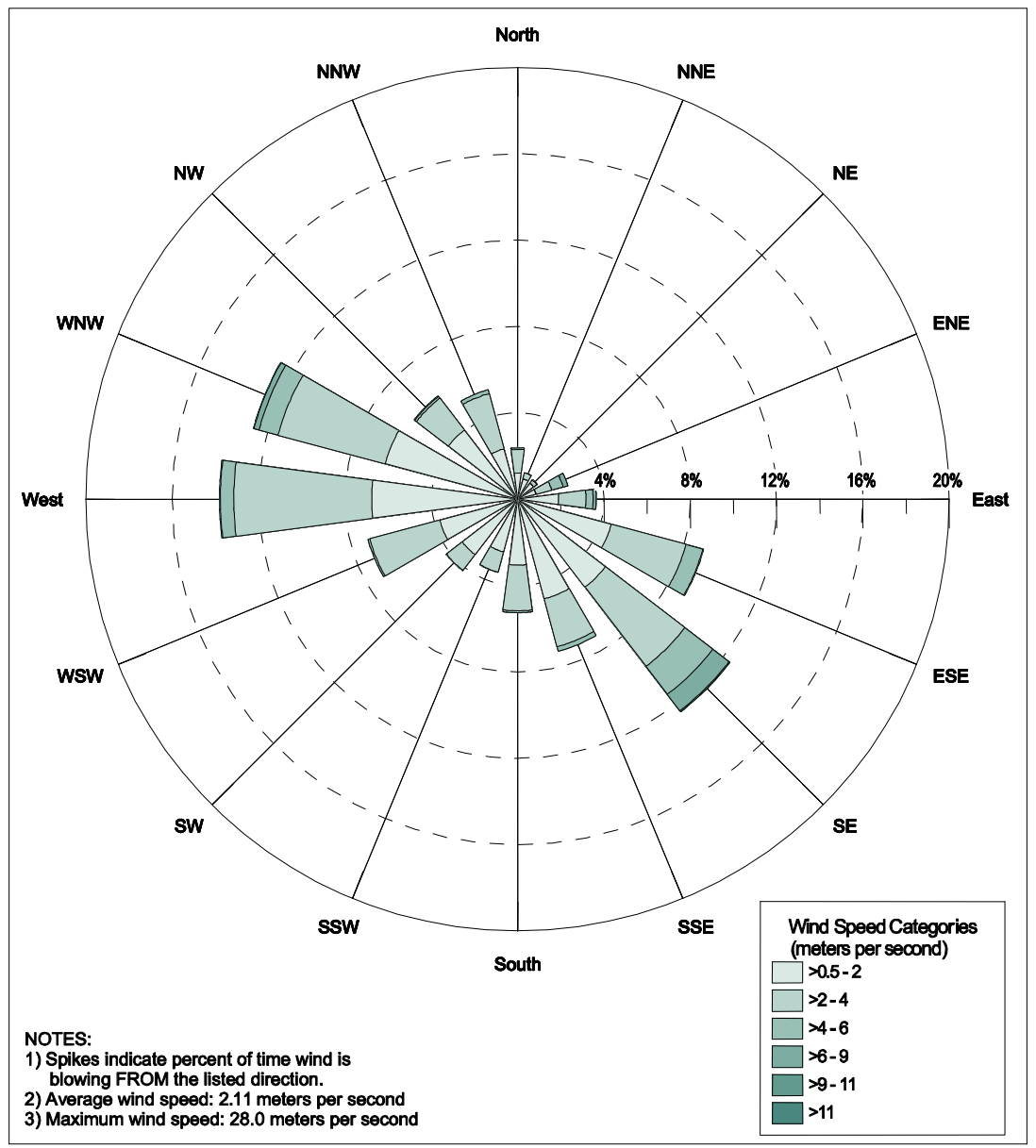

Figure 1-4 Annual Wind Patterns 
months. South-to-southeast winds in advance of each storm are followed by a shift to west or northwest winds after passage of the system.

\subsubsection{Vegetation}

Vegetation on the Berkeley Lab site is a mixture of native plants, naturalized exotics, and ornamental species. The site was intensively grazed and farmed for approximately 150 years before the development of the Laboratory at this site in the 1930s. At the main site, the Laboratory manages on-site vegetation so that it is coordinated with the local natural succession of native plant communities. Berkeley Lab also works to maintain a wooded and savanna character in the areas surrounding buildings and roads. Ornamental species are generally restricted to public spaces and courtyards and to areas adjacent to buildings. The site has no rare, threatened, or endangered species of plants present. Figure 1-5 shows the vegetation types and locations on-site.

The Lab's main site is managed to minimize wildland fire damage to structures. The vegetation management program is designed to reduce the potential flame heights of groundcover vegetation to no more than $0.9 \mathrm{~m}$ (3 ft).

The following vegetation management is conducted annually:

- Cutting off tree limbs below a minimum of 1.8 to $2.4 \mathrm{~m}$ (6 to $8 \mathrm{ft}$ ) from the ground (depending on species)

- Cutting grasses to a maximum of $7.6 \mathrm{~cm}$ (3 in)

- Removing brush, except ornamental bushes, throughout the vegetation management area

The purpose of these vegetation management (fuel reduction) efforts is to substantially reduce the intensity of any future fire storm. As a result, Laboratory buildings would more likely survive such a fire, and the lowerintensity fire conditions at the Laboratory would allow regional fire fighters to suppress the flame front so that it would not proceed to the west of the Laboratory.

Berkeley Lab also works with the Hills Emergency Forum (comprised of representatives from the neighboring cities of Berkeley and Oakland, the East Bay Regional Park District, EBMUD, and UC Berkeley) to improve vegetation management of the urban-wildland interface in the areas adjacent to the Laboratory.

\subsubsection{Wildlife}

Wildlife is abundant in the area surrounding Berkeley Lab because the site is adjacent to open spaces managed by the East Bay Regional Park District and the University of California. Wildlife that frequents the Laboratory site is typical of wildlife in disturbed (e.g., previously grazed) areas that have a Mediterranean climate and are located in midlatitude California. More than 120 species of birds, mammals, and reptiles/amphibians are thought to exist on the site. The most abundant large mammal is the Columbian black-tailed deer.

\subsubsection{Protected Habitats}

Specific instances of habitat protected by various environmental laws exist onsite. These are:

- Lee's Micro-Blind Harvestman. (Microcina Leei) is listed as a "special animal" by the California Department of Fish and Game; however, it is not considered by the state to be a special status species. It was once proposed to be a federal "candidate" species under the Endangered Species Act, but it has not been so designated by the U.S. Fish and Wildlife Service (USFWS) and is no longer proposed for federal listing. This arachnid was first identified on the main site in the 1960s and again in the 1980s. An area of the Laboratory on the south-facing slope of Blackberry Canyon has been identified as the type of locality where the 


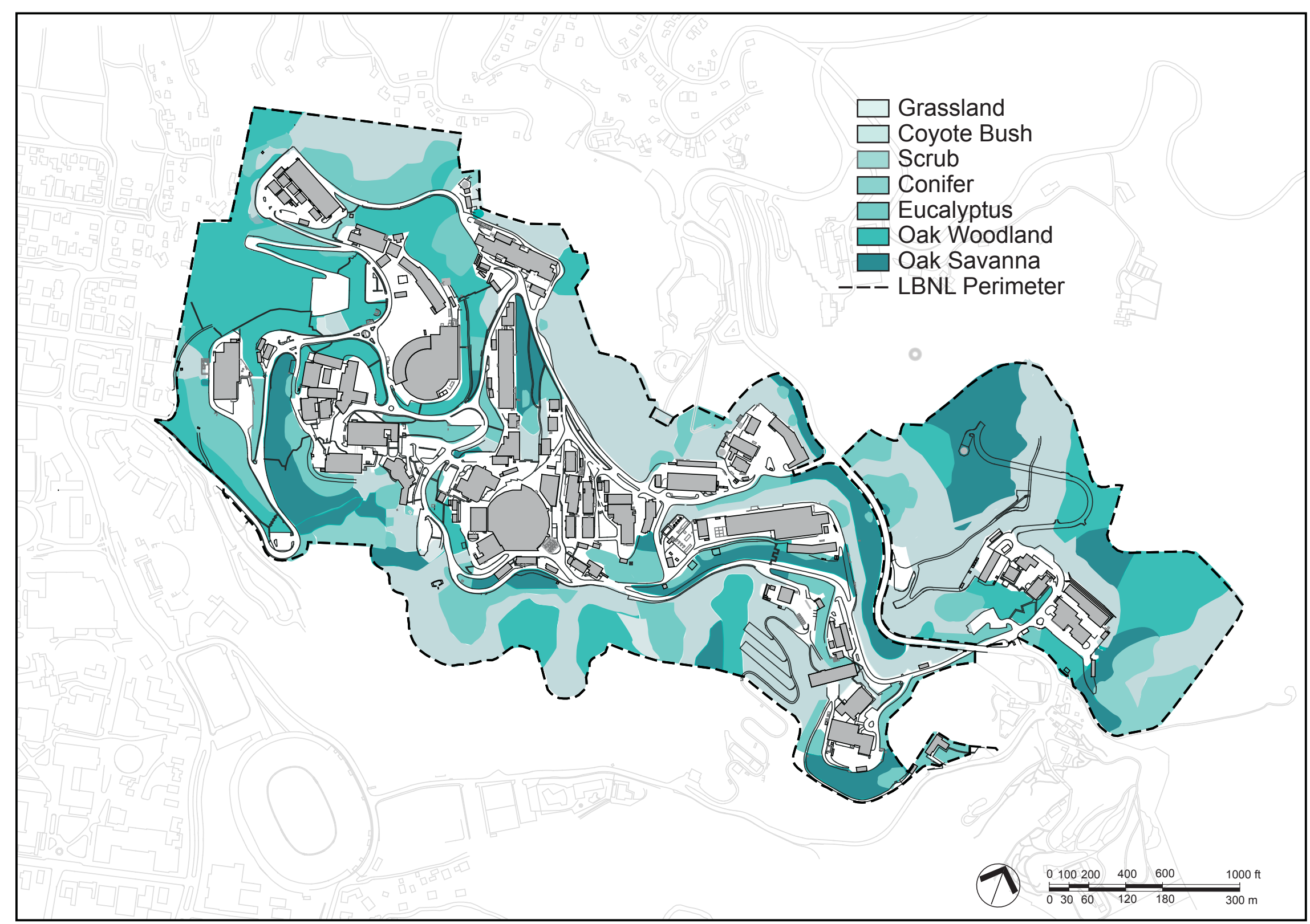

Figure 1-5 Vegetation Types 
species occurs. This area consists of a dense canopy of oak-bay woodland with undisturbed sandstone rocks that are embedded in the soil and have moist conditions underneath. ${ }^{6}$

- Alameda Whipsnake. This snake species (Masticophis lateralis euryxanthus) is listed as threatened under both federal and state law and is found in open-canopied shrub communities, including coastal scrub and chaparral, and adjacent habitats including oak woodland, savanna, and grassland areas. An approximately five-acre area at the eastern boundary of the Lab is included in the USFWS' critically designated habitat for the Alameda whipsnake. In addition, the entire Laboratory site was surveyed for whipsnake suitability in 2006. Several undeveloped areas of the Lab were identified as having high and moderate "potential" or suitability for habitation by the Alameda whipsnake. ${ }^{7}$ Nevertheless, no reported sightings of the Alameda whipsnake have ever occurred at the Lab, including during recent biological surveys. A trapping survey is being conducted in the summer of 2008.

- Riparian and Wetland Habitat. A number of drainages, including potentially "jurisdictional" drainages as defined under the Clean Water Act, exist on the main site; some are ephemeral or intermittent, and others, such as the North Fork of Strawberry Creek and Chicken Creek, are perennial. All jurisdictional waterways warrant special attention and protection under the Clean Water Act. These jurisdictional drainages, along with four freshwater seeps, appear to support riparian habitat. ${ }^{8}$

\subsubsection{Geology and Hydrogeology}

1.2.7.1 Soils

The Moraga Formation, the Orinda Formation, and the Great Valley Group constitute the principal bedrock units underlying the site. These formations and their properties are described below:
1. The western and southern parts of Berkeley Lab are underlain by marine siltstones and shales of the Great Valley Group. The permeability of these rock types is relatively low, with the movement of groundwater primarily controlled by flow through open fractures rather than through pore spaces.

2. Nonmarine sedimentary rocks of the Orinda Formation overlie the Great Valley Group and constitute the exposed bedrock over most of the developed area of the site. The Orinda Formation consists primarily of sandstones, mudstones, and conglomerates deposited in fluvial and alluvial environments. The Orinda Formation typically has lower values of hydraulic conductivity (measure of the rate at which water can move through a permeable medium) than the underlying Great Valley Group or overlying Moraga Formation, and therefore it impedes the horizontal and vertical flow of groundwater.

3. The Moraga Formation consists of volcanic rocks that underlie most of the higher elevations of Berkeley Lab, as well as much of the central developed area ("Old Town"), and constitutes the main water-bearing unit at Berkeley Lab. Although the permeability of the rock is low, groundwater flows readily through the numerous open fractures.

In addition to the three main units described above, the Claremont Formation and San Pablo Group underlie the easternmost area of the site. The Claremont Formation consists of marine chert and shale. The San Pablo Group consists of marine sandstones.

Surficial materials at the Laboratory consist primarily of soil, colluvium (soil accumulated at the foot of a slope), and artificial fill. Soil derived primarily from the bedrock units has accumulated to thicknesses of typically one to several meters across much of the site. Cutting and filling of the hilly terrain 
has been necessary to provide suitable building sites, resulting in up to tens of meters of engineered cuts and fills at some locations.

\subsubsection{Groundwater}

The groundwater elevation map of Berkeley Lab (Figure 1-6) shows that the water table approximately mirrors surface topography, such that groundwater flow in the western portion of Berkeley Lab is generally westwards, whereas flow in the remainder of the site is generally southwards. The depth to groundwater varies from approximately 0 to $30 \mathrm{~m}$ (98 ft) below the surface.

In some areas, due to the subsurface geometry and physical characteristics of the different geologic units, groundwater flow directions vary from the general trends presented on the groundwater elevation map.

Groundwater is a concern at the Laboratory because of its potential effect on slope stability and on the underground movement of contaminants (see Section 4.4). The Laboratory has carried out a successful program of slope stabilization to reduce the risk of property damage caused by soil movement. This program includes construction of subsurface drain lines (hydraugers), vegetation cover, and soil retention structures.

\subsubsection{Seismicity}

The active Hayward Fault, a branch of the San Andreas Fault System, runs from northwest to southeast along the base of the hills at the western boundary of Berkeley Lab. The inactive Wildcat Fault traverses the site from north to south along the canyon at the Laboratory's eastern edge. 


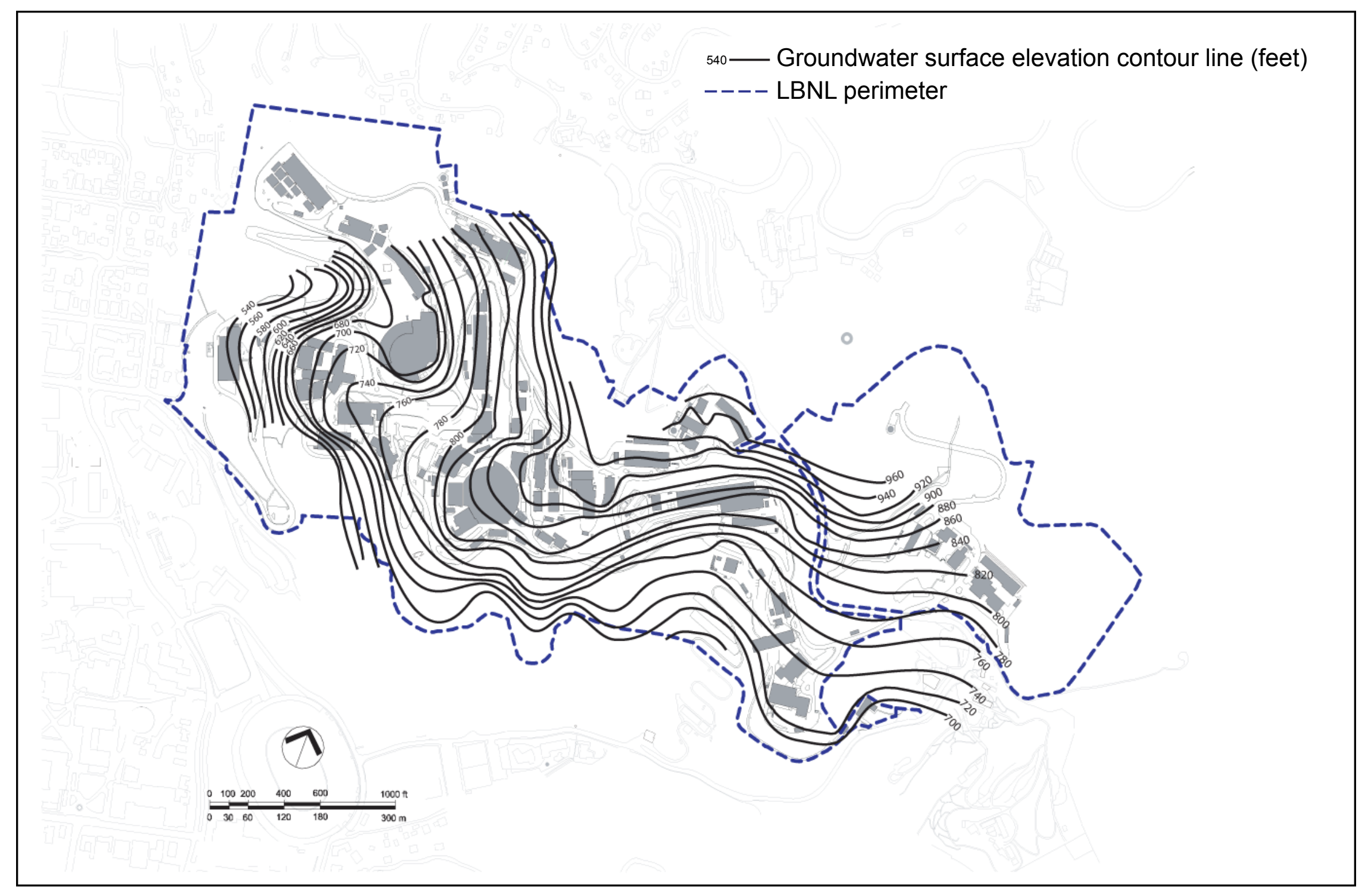

Figure 1-6 Groundwater Elevation Map 


\section{Performance-Based Environmental Management System}

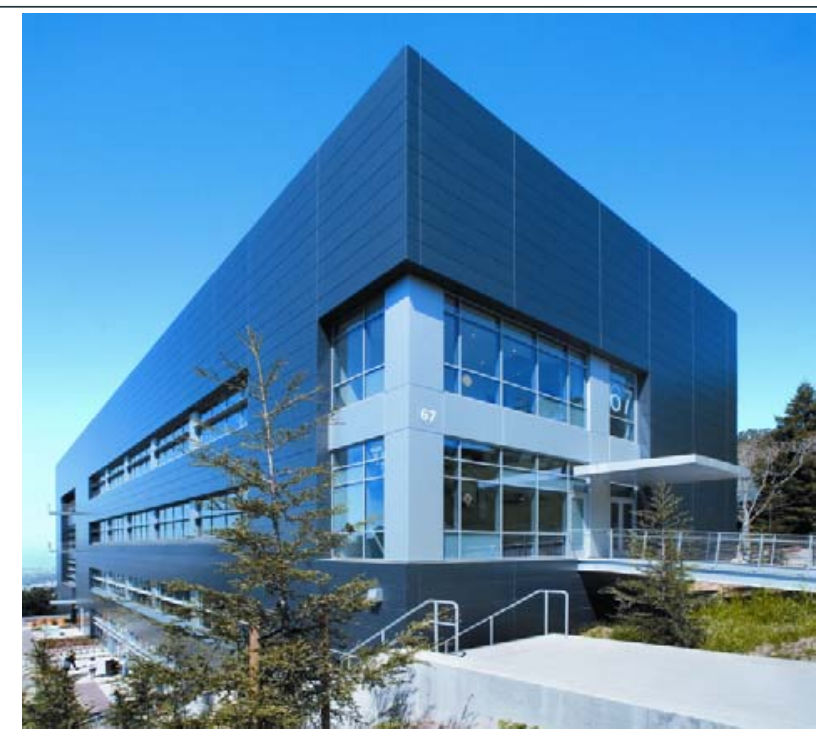

Berkeley Lab's Molecular Foundry Building has been awarded a U.S. Green Building Council's Leadership in Energy and Environmental Design (LEED) gold certification.

21 SUMMARY 2-2

BACKGROUND

INTEGRATIONOFEMSINTOISM

IMPLEMENTATION

2.4.1 EMS Core Team

2.4.2 Environmental Aspects

2.4.3 Environmental Management Programs

2.4.4 Training

2.4.5 Appraisals

2.4.6 Management Review 


\subsection{SUMMARY}

To continually improve environmental stewardship, Berkeley Lab has established a performance-based Environmental Management System (EMS a systematic approach to ensuring that environmental activities are wellmanaged and provide business value. This approach includes those components of the ISO 14001 EMS $^{1}$ standard that provide the most value, which allows the Laboratory to focus resources on those activities that have important environmental benefits while maintaining and building on the strengths of the current environmental compliance programs. The goals of the Laboratory's EMS are the following:

- Compliance with applicable environmental and public health laws and regulations

- Prevention of pollution and conservation of natural resources

- Continual improvement of the Laboratory's environmental performance

United States Executive Order 13148, Greening the Government through Leadership in Environmental Management, ${ }^{2}$ required all federal agencies to implement an EMS by December 31, 2005. DOE Order 450.1, Environmental Protection Program, ${ }^{3}$ established the EMS requirement for all DOE facilities and mandated that the EMS be integrated with existing Integrated Safety Management (ISM) systems. In a letter dated December 28, 2005, the DOE Berkeley site manager notified the director of the Office of Science that the Berkeley Lab EMS conforms to DOE Order 450.1. In January 2007, Executive Order 13423, Strengthening Federal Environmental, Energy, and Transportation Management, ${ }^{4}$ was released and established new and updated goals, practices, and reporting requirements for environmental, energy, and transportation performance and accountability.

In 2007, an EMS Core Team, composed of representatives from Berkeley Lab's Environment, Health, and Safety (EH\&S), Facilities, and Procurement organizations, continued the annual cycle of implementing the following tasks:

- Identification of aspects and impacts

- Development of objectives and targets

- Preparation of Environmental Management Programs (EMPs)

- Performance of assessments

\subsection{BACKGROUND}

Neither Executive Order 13148 nor DOE Order 450.1 required that the organization's EMS meet a recognized standard, such as the ISO 14001 standard for EMSs. So, in 2002, before Berkeley Lab had developed its EMS approach, an analysis was performed to identify whether gaps existed between then-current programs and systems and each element required by an ISO 14001 EMS. Relevant Berkeley Lab documents were reviewed, and appropriate program managers were interviewed. The results from the analysis indicated where deficiencies existed for each element. Potential actions required to address each gap were identified, and each element was evaluated for its significance in assuring environmental compliance and improving environmental performance.

As a result, Berkeley Lab developed and implemented a performance-based EMS - a systematic approach to ensuring that environmental stewardship activities are not only well managed but also provide business value. Accordingly, the EMS was based on the work, the environment in which the work is performed, and the hazards or risks associated with the work at the Laboratory. The performance-based approach includes those components of ISO 14001 that provide the most value, rather than simply all the components of an ISO 14001-type of EMS, regardless of value. This approach allows Berkeley Lab to focus resources on those activities that have a greater 
environmental benefit and to maintain the current strengths of the environmental compliance programs.

A system was established that incorporated an annual cycle of planning, implementing, evaluating, and improving processes and actions to achieve the EMS goals (Figure 2-1).

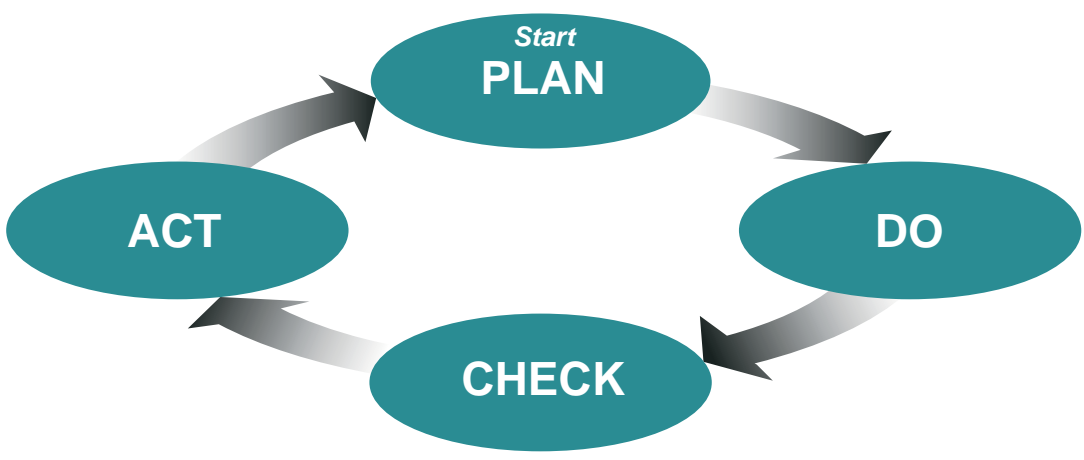

Figure 2-1 Cycle of Activities That Are Performed to Achieve EMS Goals

Berkeley Lab's EMS program was documented in the Performance-Based Environmental Management System Plan. ${ }^{5}$ This document, as well as other EMSrelated documentation, is available at the following Web site: http://www.lbl.gov/ehs/esg/emsplan/emsplan.htm.

\subsection{INTEGRATION OF EMS INTO ISM}

Berkeley Lab's EMS has been integrated with the Laboratory's ISM system. To the extent that it has been practical, ISM processes have been used to support environmental performance improvement and compliance management. Where it has been impractical, new processes were developed to support the EMS and were integrated with the ISM.

Both the EMS and ISM strive for continual improvement through a plan-docheck-act cycle. This cycle calls for defining the scope and purpose of the system, followed by a planning (plan) step to develop programs and procedures that must then be implemented (do). Once implemented, programs must be assessed (check) and any problems corrected (act) to improve the effectiveness of the management system and to achieve improved environment, safety, and health performance.

\subsection{IMPLEMENTATION}

The following six areas are key to the implementation of the Laboratory's performance-based EMS program:
1. EMS Core Team
2. Environmental aspects
3. EMPs
4. Training
5. Appraisals
6. Management review

The 2007 activities for each of these key areas are described below.

\subsubsection{EMS Core Team}

The Core Team implemented and maintained LBNL's EMS to manage environmental compliance matters and to reduce environmental impacts over time. In 2007, it consisted of key representatives from the EH\&S, Facilities, and Procurement organizations that were most knowledgeable of environmental management concerns. The team was led by a representative of the EH\&S organization. A representative from the DOE Berkeley Site Office also attended the meetings to maintain an operational awareness of the EMS Core Team activities. The primary functions of the Core Team were the following:

- Identification of environmental aspects

- Determination of significant impacts

- Development of objectives and targets for the significant aspects

- Preparation and implementation of the EMPs

- Evaluation of all EMPs annually 
- Coordination of internal assessments of the EMS

- Review of performance results

- Preparation of recommendations to management on improvements to the EMS

- Coordination of the annual management review of the EMS

- Coordination of internal communications about the EMS

\subsubsection{Environmental Aspects}

The Core Team identified environmental aspects: activities or services that may produce a change to the environment - whether adverse or beneficialresulting from Berkeley Lab operations. In addition, the Core Team determined the significance of each aspect's potential impact, using the following factors to shape its decisions:

- Severity of impact

- Duration of impact

- Probability of occurrence

- Cost of addressing impact

- Effect on public image

- Effect on Laboratory mission

- Potential legal exposure

- Potential for improvement

Each impact was given a numeric rating based on a three-tiered scoring system: high (3), medium (2), and low (1). Average scores and overall ratings for each impact were determined and used to provide a starting point for the significance determination. Before a final significance determination was made, the Core Team members devoted one of its meetings to a discussion of each activity and associated impacts.

\subsubsection{Environmental Management Programs}

Seven activities were determined to be significant in 2007, and objectives and targets were developed for reducing their environmental impacts:
- Sanitary (solid) waste generation

- Diesel particulate matter emissions

- Energy use

- Water use

- Fleet petroleum use

- Environmentally preferable purchasing

- Traffic congestion (draft)

The objectives and targets were formally documented in an EMP. Each EMP also established strategies and actions needed to achieve the objectives and targets; developed procedures, metrics, or techniques; and set up schedules. An EMP leader was selected from the Core Team members to coordinate actions and monitor the performance of each EMP. The traffic congestion EMP was not finalized in 2007.

\subsubsection{Training}

In Berkeley Lab's EMS approach, training is targeted and graded, commensurate with the EMS activity. The following four levels of training were maintained in 2007:

- General EMS awareness

- Comprehensive EMS awareness

- EMS implementation

- EMS auditor

\subsubsection{Appraisals}

Internal assessments of the EMS program and activities are performed annually. The assessments determine whether the EMS activities conform to the requirements of the Laboratory's EMS program plan and whether it has been properly implemented and maintained. Additionally, the assessor may review the performance of the EMPs. The EMS program was reviewed by Berkeley Lab's Office of Contract Assurance (OCA) in 2007. The assessment determined that the EMS program was successful at identifying 
significant impacts and developing EMPs to address them. The 2007 management review did not include all of the appropriate participants, and this resulted in a finding. Two noteworthy practices and five observations were also noted. The internal assessment results were presented to a Berkeley Lab senior management team during the management review meeting. The finding was placed into the Laboratory's Corrective Action Tracking System.

In August 2007, the DOE conducted a review to verify that LBNL continues to implement and integrate the EMS as required by DOE Order 450.1, Emvironmental Protection Program, and is performing the activities required by its EMS program. DOE found that the Laboratory's EMS was functioning as required by their Order 450.1, with the exception of one finding: a significant gap exists in the program that allows an EMP to be closed without actually meeting a target or documentation of some other reason. The DOE review also commented favorably on a particularly noteworthy practice regarding LBNL's comprehensive internal EMS review practices.

Additionally, on a three-year cycle, LBNL retains a third-party auditor to determine whether the Laboratory's EMS activities conform to the requirements of the EMS Plan and whether it has been properly implemented and maintained. The next third-party review is planned for the end of 2008 . Representatives from DOE will be invited to participate as observers in the audit. The results of the validation audit also will be presented to Berkeley Lab management at the next normally scheduled management review session. A special management review may be convened if the validation audit determines any significant weaknesses in the program.

\subsubsection{Management Review}

The status of the EMS is reviewed annually by a Berkeley Lab senior management team as appropriate for the activities involved. Based on this review, the Laboratory's management may determine changes needed in the EMS program: factors such as improved assessment methodologies or major changes to the facility's mission, products, and processes are considered in determining the need for changes. The 2007 review included discussions of EMS principles, activities, accomplishments, and the results of EMS assessments performed since the last management review. The management team recommended more attention be given to maintaining EMS training requirements and establishing backups for EMS team members. They also agreed that compliance with the ISO 14001 EMS standard is not warranted.

\subsection{ENVIRONMENTAL MANAGEMENT PROGRAMS}

Based on the EMS Core Team's review of environmental aspects and impacts, seven areas were identified for potential improvement. In each case, objectives and targets were developed and an EMP established to improve the Laboratory's environmental performance in the specific area. Table 2-1 summarizes the projects that were undertaken in 2007. 
Table 2-1 Environmental Management Programs for 2007

\begin{tabular}{|c|c|c|}
\hline Aspect/Activity & Objective(s) & Target(s) \\
\hline $\begin{array}{l}\text { Sanitary (Solid) } \\
\text { Waste Generation }\end{array}$ & $\begin{array}{l}\text { Increase solid waste } \\
\text { diversion }\end{array}$ & $\begin{array}{l}\text { Divert at least } 5 \% \text { of solid waste } \\
\text { by the end of FY08 relative to the } \\
\text { FY06 baseline year. }\end{array}$ \\
\hline $\begin{array}{l}\text { Diesel Particulate } \\
\text { Matter (DPM) } \\
\text { Emissions }\end{array}$ & $\begin{array}{l}\text { Implement alternatives } \\
\text { for reducing DPM } \\
\text { emissions from mobile } \\
\text { and stationary sources }\end{array}$ & $\begin{array}{l}\text { Reduce DPM emissions } 5 \% \text { per } \\
\text { year relative to a CY05 baseline } \\
\text { year. }\end{array}$ \\
\hline Energy Use & $\begin{array}{l}\text { Implement sustainable } \\
\text { practices for energy } \\
\text { efficiency }\end{array}$ & $\begin{array}{l}\text { Reduce energy intensity by } 3 \% \\
\text { annually or } 30 \% \text { by } 2015 \text { relative } \\
\text { to the FY03 baseline year. }\end{array}$ \\
\hline Water Use & $\begin{array}{l}\text { Implement sustainable } \\
\text { practices for water } \\
\text { consumption intensity }\end{array}$ & $\begin{array}{l}\text { Reduce water consumption } \\
\text { intensity by } 2 \% \text { annually or } 16 \% \\
\text { by the end of } 2015 \text { relative to the } \\
\text { FY07 baseline year. }\end{array}$ \\
\hline Fleet Petroleum Use & $\begin{array}{l}\text { Reduce fleet petroleum } \\
\text { consumption }\end{array}$ & $\begin{array}{l}\text { Reduce fleet's annual petroleum } \\
\text { consumption by } 2 \% \text { annually } \\
\text { using FY05 fleet fuel } \\
\text { consumption as a baseline. }\end{array}$ \\
\hline $\begin{array}{l}\text { Environmentally } \\
\text { Preferable } \\
\text { Purchasing }\end{array}$ & $\begin{array}{l}\text { Increase procurement of } \\
\text { Energy Star Products } \\
\text { (ESP) and Recycled } \\
\text { Content Products (RCP) }\end{array}$ & $\begin{array}{l}\text { Track ESP procurements in } \\
\text { FY07 to develop a baseline year. } \\
\text { Increase RCP procurements by } \\
5 \% \text { each year using FY05 as the } \\
\text { baseline year. }\end{array}$ \\
\hline $\begin{array}{l}\text { Traffic Congestion } \\
\text { (Draft) }\end{array}$ & $\begin{array}{l}\text { Reduce Laboratory } \\
\text { commute traffic through } \\
\text { Transportation Demand } \\
\text { Management }\end{array}$ & $\begin{array}{l}\text { Maintain a } 1.7 \text { to } 1 \text { ratio of } \\
\text { parking spaces per person } \\
\text { through FY07. }\end{array}$ \\
\hline
\end{tabular}


3 Environmental Program Summary

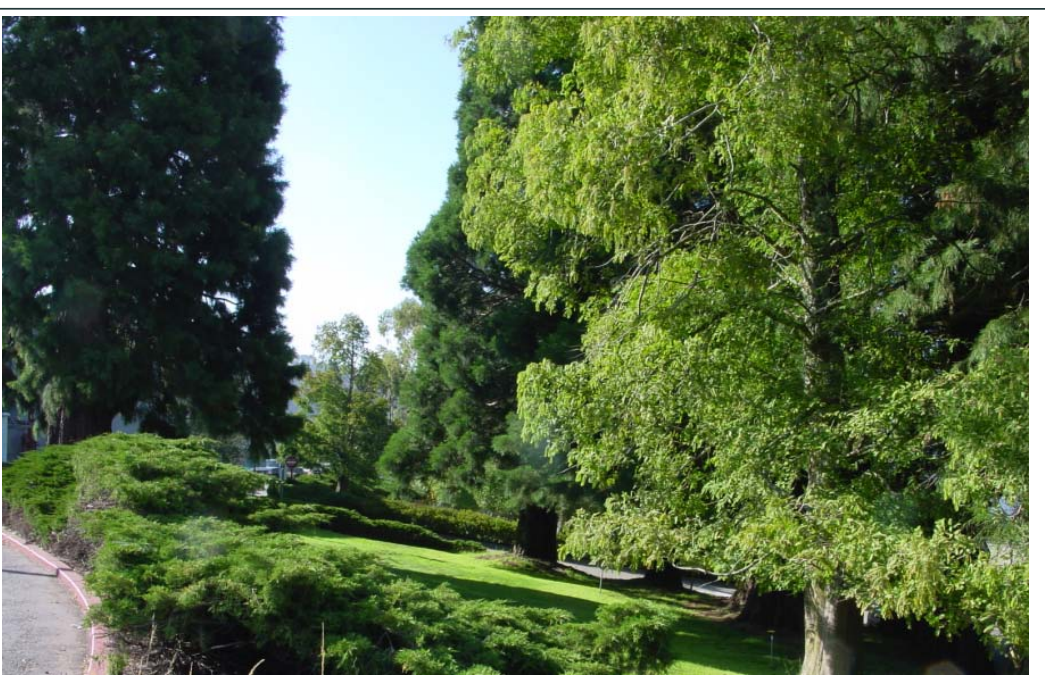

Lawn area between Building 25 and Building 4

3.2 OVERMEWOFEMMONMENTAL RESPONSIBIUTTES

3.2.1 Environmental Management System

3.3.1 Summary of Environmental Permits

3.3.2 Summary of Audits and Inspections

3.3.3 Summary of DOE-Reportable

Environmental Incidents 
3.4.2 Comprehensive Environmental Response, Compensation, and Liability Act

3.4.3 Emergency Planning and Community

Right-to-Know Act

3.4.3.1 Toxic Release Inventory

3.4.3.2 Hazardous Materials Business Plan

3.4.3.3 Risk Management and Prevention Plan

3.4.4 Federal Insecticide, Fungicide, and Rodenticide Act

3.4.5 Toxic Substances Control Act

3.4.6 Resource Conservation and Recovery Act

3.4.6.1 Hazardous Waste

3.4.6.2 Medical Waste

3.4.6.3 Corrective Action Program

3.4.7 Executive Order 13423 (Strengthening Federal

Environmental, Energy, and Transportation

Management)

3.4.8 Hazardous Waste Source Reduction and Management Review Act

3.4.9 Pollution Prevention Act of 1990

3.4.10 Clean Water Act

3.4.10.1 Wastewater

3.4.10.2 Stormwater

3.4.10.3 Aboveground Storage Tanks

3.4.10.4 Underground Storage Tanks

3.4.11 Safe Drinking Water Act

3.4.12 National Environmental Policy Act and California

Environmental Quality Act
3-9

3-9

3-9

3-9

3-10

3-11

3-12
3.4.13 Federal Endangered Species Act

3-18

3.4.14 California Endangered Species Act

3-18

3.4.15 National Historic Preservation Act

3-18

3.4.16 Migratory Bird Treaty Act

3-18 


\subsection{INTRODUCTION}

This chapter provides an overview of Lawrence Berkeley National Laboratory's environmental protection program, reviews the status of various compliance programs and activities, and presents measures of the Laboratory's environmental performance in key areas for 2007.

\subsection{OVERVIEW OF ENVIRONMENTAL RESPONSIBILITIES}

To provide the highest degree of protection for the public and the environment, Berkeley Lab applies the principles of ISM to Laboratory activities. This involves the performance of five core functions. ${ }^{1}$

- Work Planning. Clear definition of the tasks that are to be accomplished as part of any given activity.

- Hazard and Risk Analysis. Analysis and determination of the hazards and risks associated with any activity; in particular, risks to employees, the public, and the environment.

- Establishment of Controls. Controls that are sufficient to reduce the risks associated with any activity to acceptable levels. Acceptable levels are determined by responsible line management, but are always in conformance with all applicable laws and Work Smart Standards.

- Work Performance. Conduct of the tasks to accomplish the activity in accordance with the established controls.

- Feedback and Improvement. Implementation of a continuous improvement cycle for the activity, including incorporation of employee suggestions, lessons learned, and employee and community outreach, as appropriate.

The EH\&S Division at Berkeley Lab is responsible for administering environmental protection and compliance programs at the Laboratory. The organizational structure of EH\&S as of the end of 2007 is shown in Figure 3-1. Environmental protection programs are largely administered by two EH\&S organizations:

- The Environmental Services Group (ESG) oversees sitewide air and water quality compliance activities, provides technical assistance to Laboratory staff, and manages environmental characterization and

\section{ENVIRONMENT, HEALTH \& SAFETY DIVISION}

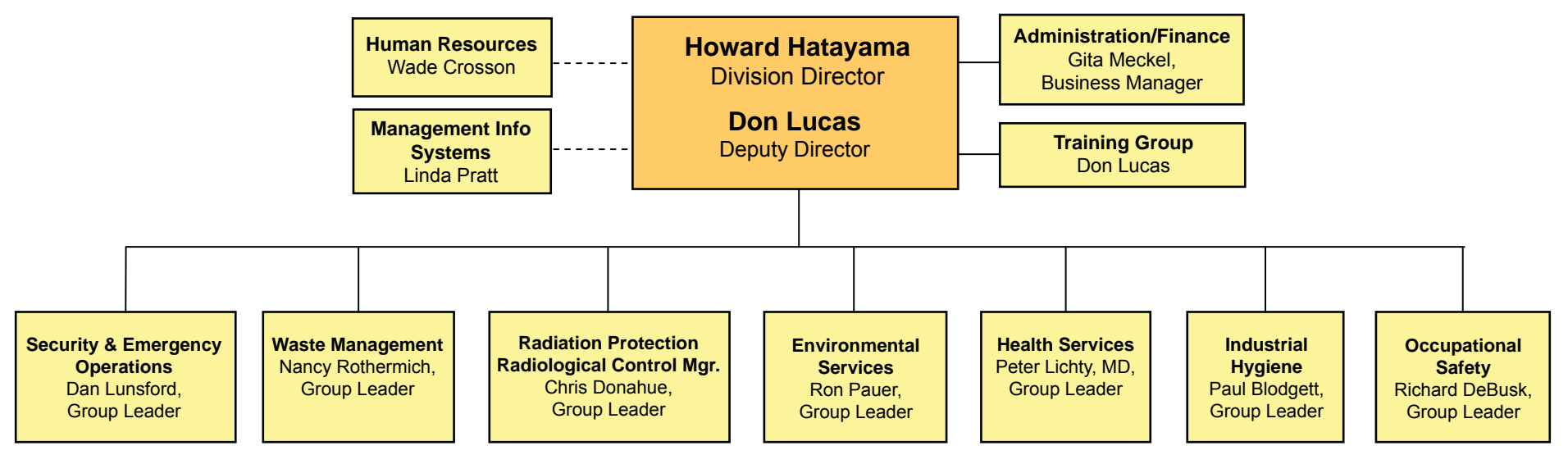

Figure 3-1 Berkeley Lab Environment, Health, and Safety Division Organization in 2007 
cleanup. These programs include environmental monitoring activities that provide information critical to demonstrating compliance and making programmatic decisions. (For monitoring result summaries, see Chapter 4.)

- The Waste Management Group manages hazardous, medical, radioactive mixed (hazardous and radioactive), and universal waste generated at the Laboratory.

\subsubsection{Environmental Management System}

To continually improve environmental performance, Executive Order $13148^{2}$ required all federal agencies to implement an EMS by December 31, 2005. An EMS is a systematic approach to achieving environmental goals. DOE Order $450.1^{3}$ established the EMS requirement for all DOE facilities and, in addition, mandated that the EMS be integrated with existing ISM systems.

To meet the DOE Order 450.1 requirements, Berkeley Lab established a performance-based EMS that ensured environmental activities were not only well managed but also provided business value. This approach included those components of the ISO $14001 \mathrm{EMS}^{4}$ standard that were determined to provide the most value, which allowed the Laboratory to focus resources on those activities that have important environmental benefits while maintaining and building on the strengths of the current environmental compliance programs. A system was established that incorporated an annual cycle of planning, implementing, evaluating, and improving processes and actions to meet EMS performance goals. For details on the performance-based EMS, see Chapter 2.

\subsection{PROGRAM SUMMARY}

The following sections discuss environmental permits, audits, inspections, and DOE-reportable environmental incidents at Berkeley Lab for 2007.

\subsubsection{Summary of Environmental Permits}

Some Berkeley Lab activities require operating permits from environmental regulatory agencies. Table 3-1 summarizes, by area of environmental activity, the 45 active permits held by the Laboratory at the end of the year.

Table 3-1 Environmental Permits Held by Berkeley Lab at the End of 2007

\begin{tabular}{|c|c|c|c|c|}
\hline $\begin{array}{l}\text { Type of } \\
\text { Permit }\end{array}$ & $\begin{array}{l}\text { Issuing } \\
\text { Agency }\end{array}$ & Description & $\begin{array}{l}\text { Number } \\
\text { of } \\
\text { Permits }\end{array}$ & $\begin{array}{l}\text { Section for } \\
\text { More } \\
\text { Information }\end{array}$ \\
\hline Air quality & $\mathrm{BAAQMD}^{\mathrm{a}}$ & $\begin{array}{l}\text { Various activities with } \\
\text { emissions to air }\end{array}$ & 32 & 3.4 .1 .2 \\
\hline \multirow[t]{2}{*}{$\begin{array}{l}\text { Hazardous } \\
\text { waste }\end{array}$} & DTSC $^{b}$ & $\begin{array}{l}\text { Hazardous Waste } \\
\text { Handling Facility } \\
\text { operations }\end{array}$ & 1 & 3.4.6.1 \\
\hline & $\begin{array}{l}\text { City of } \\
\text { Berkeley }\end{array}$ & $\begin{array}{l}\text { Fixed treatment units } \\
\text { (5) }\end{array}$ & 1 & 3.4.6.1 \\
\hline Stormwater & SWRCB $^{\mathrm{c}}$ & $\begin{array}{l}\text { Sitewide stormwater } \\
\text { discharges }\end{array}$ & 1 & 3.4 .10 .2 \\
\hline $\begin{array}{l}\text { Underground } \\
\text { storage tanks }\end{array}$ & $\begin{array}{l}\text { City of } \\
\text { Berkeley }\end{array}$ & $\begin{array}{l}\text { Underground storage } \\
\text { tanks containing } \\
\text { petroleum products }\end{array}$ & 6 & 3.4.10.4 \\
\hline \multirow[t]{2}{*}{ Wastewater } & EBMUD $^{d}$ & $\begin{array}{l}\text { Sitewide and } \\
\text { operation-specific } \\
\text { wastewater } \\
\text { discharges to sanitary } \\
\text { sewer }\end{array}$ & 3 & 3.4.10.1 \\
\hline & $\operatorname{CCCSD}^{\mathrm{e}}$ & $\begin{array}{l}\text { Wastewater } \\
\text { discharges to sanitary } \\
\text { sewer at Joint } \\
\text { Genome Institute in } \\
\text { Walnut Creek }\end{array}$ & 1 & 3.4 .10 .1 \\
\hline $\begin{array}{l}{ }^{\text {a }} \text { Bay Area Air Qui } \\
{ }^{b} \text { Department of TC } \\
\text { c State Water Res } \\
\text { d East Bay Municip } \\
\text { e Central Contra C }\end{array}$ & $\begin{array}{l}\text { lity Manageme } \\
\text { xic Substances } \\
\text { urces Control } \\
\text { al Utility Distric } \\
\text { osta Sanitary D }\end{array}$ & $\begin{array}{l}\text { District } \\
\text { ontrol } \\
\text { ard }\end{array}$ & & \\
\hline
\end{tabular}




\subsubsection{Summary of Audits and Inspections}

The agencies that regulate the environmental programs at Berkeley Lab periodically inspect the Laboratory. Table 3-2 lists the inspections by these agencies that occurred at Berkeley Lab during the year. Table 3-2 includes self-monitoring inspections conducted by Berkeley Lab that are required by EBMUD wastewater discharge permits because these activities expose the Laboratory to potential regulatory violations.

Two violations were issued by the City of Berkeley in 2007 as a result of labeling and inspection practices at the two Fixed Treatment Units. In addition, the DPH Medical Waste Management Unit issued seven violations for minor storage and labeling issues. One violation was contested. Two violations were received from DTSC in March of 2007, but do not appear in Table 3-2 because the inspection took place in 2006.

\subsubsection{Summary of DOE-Reportable Environmental Incidents}

Six environmental incidents were reportable under the DOE occurrencereporting program ${ }^{5}$ used to track incidents across the DOE complex:

- In March 2007, Berkeley Lab received the final report from the May 2006 DTSC inspection of the Hazardous Waste Handling Facility (HWHF) citing two Class II violations. Both violations cited a discrepancy between the accumulation start date on a hazardous waste container and the accumulation start date for the container in the HWHF operating record.

- In March 2007, Berkeley Lab entered into a consent order with DTSC concerning findings from inspections between 2003 and 2005. These violations were discussed in previous Site Environmental Reports. Specifically, the Laboratory agreed to pay a penalty of $\$ 28,000$ for accepting hazardous waste from off-site, in this case from Building 903, and transporting hazardous materials to the Building 903 warehouse, which is not authorized to accept hazardous waste. The Laboratory also held hazardous waste in a Satellite Accumulation Area for more than one
Table 3-2 Environmental Audits, Inspections, and Appraisals in 2007

\begin{tabular}{|c|c|c|c|c|}
\hline \multicolumn{2}{|r|}{ Inspection Title } & \multirow{2}{*}{$\begin{array}{l}\text { Start Date } \\
\text { June } 21\end{array}$} & \multirow{2}{*}{$\begin{array}{c}\text { Length }^{\mathrm{a}} \\
\text { (Days) }\end{array}$} & \multirow{2}{*}{$\begin{array}{c}\text { Violations } \\
0\end{array}$} \\
\hline BAAQMD & Inspection of permitted air sources & & & \\
\hline \multirow{2}{*}{$\begin{array}{l}\text { City of } \\
\text { Berkeley }\end{array}$} & Underground storage tanks & October 31 & 1 & 0 \\
\hline & $\begin{array}{l}\text { HMBP, WAA/SAA, \& Fixed } \\
\text { Treatment Units }\end{array}$ & $\begin{array}{l}\text { September } \\
25,26,27\end{array}$ & 3 & 2 \\
\hline $\mathrm{DPH}$ & $\begin{array}{l}\text { Medical Waste Management } \\
\text { Program }\end{array}$ & April 18 & 1 & $7^{b}$ \\
\hline DTSC & $\begin{array}{l}\text { Inspection of Hazardous Waste } \\
\text { Handling Facility }\end{array}$ & $\begin{array}{l}\text { September } 21 \\
\text { October } 3,4\end{array}$ & 1 & 0 \\
\hline \multirow[t]{4}{*}{ EBMUD } & $\begin{array}{l}\text { Wastewater monitoring inspection } \\
\text { at Hearst and Strawberry outfalls }\end{array}$ & $\begin{array}{l}\text { April } 4 \\
\text { May } 30 \\
\text { June } 22 \\
\text { August } 9 \\
\text { August } 22\end{array}$ & $\begin{array}{l}1 \\
1 \\
1 \\
1 \\
1\end{array}$ & $\begin{array}{l}0 \\
0 \\
0 \\
0 \\
0\end{array}$ \\
\hline & $\begin{array}{l}\text { Wastewater monitoring inspection } \\
\text { at B25 treatment unit }\end{array}$ & $\begin{array}{l}\text { April } 4 \\
\text { May } 31\end{array}$ & $\begin{array}{l}1 \\
1\end{array}$ & $\begin{array}{l}0 \\
0\end{array}$ \\
\hline & $\begin{array}{l}\text { Wastewater monitoring inspection } \\
\text { at B77 treatment unit }\end{array}$ & $\begin{array}{l}\text { February } 21 \\
\text { May } 31\end{array}$ & $\begin{array}{l}1 \\
1\end{array}$ & $\begin{array}{l}0 \\
0\end{array}$ \\
\hline & $\begin{array}{l}\text { Wastewater monitoring inspection } \\
\text { at groundwater treatment units }\end{array}$ & October 22-23 & 32 & 0 \\
\hline \multirow[t]{4}{*}{ LBNL } & $\begin{array}{l}\text { EBMUD self-monitoring inspections } \\
\text { at Hearst and Strawberry outfalls }\end{array}$ & $\begin{array}{l}\text { April } 24 \\
\text { September } 25\end{array}$ & $\begin{array}{ll} & 1 \\
5 & 1\end{array}$ & $\begin{array}{l}0 \\
0\end{array}$ \\
\hline & $\begin{array}{l}\text { EBMUD self-monitoring inspections } \\
\text { at B77 treatment unit }\end{array}$ & $\begin{array}{l}\text { January } 30 \\
\text { July } 17 \\
\text { September } 11\end{array}$ & $\begin{array}{l}1 \\
1 \\
1\end{array}$ & $\begin{array}{l}0 \\
0 \\
0\end{array}$ \\
\hline & $\begin{array}{l}\text { EBMUD self-monitoring inspections } \\
\text { at B25 treatment unit }\end{array}$ & $\begin{array}{l}\text { February } 13 \\
\text { September } 11\end{array}$ & $\begin{array}{l}1 \\
1\end{array}$ & $\begin{array}{l}0 \\
0\end{array}$ \\
\hline & $\begin{array}{l}\text { EBMUD self-monitoring inspections } \\
\text { at groundwater treatment units }\end{array}$ & $\begin{array}{l}\text { May } 14 \\
\text { August } 14 \\
\text { November } 12\end{array}$ & $\begin{array}{l}1 \\
1 \\
1\end{array}$ & $\begin{array}{l}0 \\
0 \\
0\end{array}$ \\
\hline
\end{tabular}

A portion of a day is tabulated as one day.

${ }^{\mathrm{b}}$ One violation has been contested. 
year, which is a California Health and Safety Code violation. Berkeley Lab corrected the violations at the time they were issued and continues to work to prevent additional instances. DTSC has acknowledged that all terms and conditions of the consent order were met.

- In June 2007, wastewater from a sanitary sewer system overflowed from a sewer manhole in the Building 75 area. Environmental regulations required reporting the release to the California Office of Emergency Services, the Regional Water Quality Control Board, and the City of Berkeley.

- In June 2007, wastewater from a sanitary sewer system overflowed from a sewer manhole in the Building 90 parking lot $\mathrm{C}$ area. Environmental regulations required reporting the release to the California Office of Emergency Services, the Regional Water Quality Control Board, and the City of Berkeley.

- In June 2007, Berkeley Lab received seven notices of violation (one contested) from DPH, Medical Waste Management Program. The reports cited minor storage violations identified during DPH's April 2007 inspection of medical waste management at the LBNL main site, Donner Laboratory on the UC Berkeley campus, and LBNL's Potter Street facility.

- In October 2007, Berkeley Lab received two notices of violation for deficiencies identified during the September 2007 inspection conducted by the City of Berkeley Toxics Management Group. The violations were cited based on the State of California's Permit-By-Rule Tiered Permit requirements: the sign on the exterior of the Fixed Treatment Unit (FTU) at Building 77A-102 (FTU 006) which included emergency contact information did not include LBL's U.S. Environmental Protection Agency (U.S. EPA) identification number or the FTU identification number; and the leak detection probes for the FTU at Building 25B
(F'TU 002) had not been inspected at the frequency required per the unit's written inspection schedule.

\subsection{COMPLIANCE PROGRAMS}

The following sections provide individual summaries of the environmental compliance programs at Berkeley Lab.

\subsubsection{Clean Air Act}

The Clean Air $\mathrm{Act}^{6}$ is the key statutory reference for federal, state, and local air pollution control programs. It classifies air pollutants into these main categories:

- Criteria air pollutants (e.g., carbon monoxide, nitrogen oxides, particulate matter)

- Hazardous air pollutants (e.g., radionuclides, air toxics)

- Ozone-depleting substances (e.g., chlorofluorocarbons or Freons)

The State of California's air pollution control program ${ }^{7}$ gives it additional powers to regulate sources of air emissions.

Berkeley Lab divides its air quality protection and compliance activities into two categories: radiological (see Section 3.4.1.1) and nonradiological (see Section 3.4.1.2).

\subsubsection{Radiological}

Radionuclides released to the atmosphere from Laboratory research activities must adhere to NESHAP regulations, ${ }^{8}$ as well as sections of DOE Order 5400.5, Radiation Protection of the Public and the Environment. ${ }^{9}$ U.S. EPA administers the NESHAP regulations, which limit the dose to the public from the Laboratory's airborne radionuclide emissions to 0.10 millisievert per year (mSv/yr) (10 millirem per year $[10 \mathrm{mrem} / \mathrm{yr}]$. The Laboratory 
documents its NESHAP review and compliance at http://www.lbl.gov/ehs/esg/ under "Available Documents."

\subsubsection{Nonradiological}

The Bay Area Air Quality Management District (BAAQMD) implements federal and state air quality requirements for most air emission activities that are not addressed by NESHAP regulations.

At the end of 2007, Berkeley Lab held operating permits issued by BAAQMD for 32 emission sources, ${ }^{10}$ two fewer permits than the preceding year. Two of these operating permits cover activities located at the Production Genomics Facility in Walnut Creek, California. This facility is part of the Joint Genome Institute (JGI), a collaboration involving Berkeley Lab, Lawrence Livermore National Laboratory, and Los Alamos National Laboratory research groups. No new activities were permitted during the year at either the main or Walnut Creek sites. Two permits were canceled during the year as the equipment covered by these permits was no longer needed. The equipment included an epoxy mixing booth at Building 53 and a solvent vapor degreasing cleaning system at Building 25. For a list of active operating permits, see Table 3-3.

Operating permits are renewed annually, at which time BAAQMD also requests information required by the state's Air Toxics "Hot Spots" Information and Assessment Act of $1987 .{ }^{11}$ Activities covered by permits are subject to periodic inspection. BAAQMD conducted an inspection of permitted activities on June 21. No findings resulted from this inspection.

Berkeley Lab continued operating its E85-fuel dispensing facility at the Building 76 Motor Pool under a research-and-development test-site authorization and permit from the California Air Resources Board (CARB) and BAAQMD, respectively. E85 fuel is a mixture of $85 \%$ ethanol and 15\% unleaded gasoline. Federal mandates require that Berkeley Lab both increase the percentage of vehicles using alternative fuels and decrease the amount of petroleum used according to a given time schedule. Both BAAQMD and CARB have placed an operating condition upon this fueling station that the Laboratory perform quarterly testing of the system's vapor recovery components. Such aggressive testing is needed to provide data that will speed up the availability of CARB-certified E85-fuel dispensing equipment to the entire California marketplace. Berkeley Lab remains one of a limited number of sites in all of California authorized to dispense this alternative fuel.

Table 3-3 Air Emission Sources Permitted by BAAQMD a at the End of 2007

\begin{tabular}{|c|c|c|c|}
\hline BAAQMD Category & Description & Building & $\begin{array}{l}\text { Abatement } \\
\text { Type }\end{array}$ \\
\hline \multirow[t]{4}{*}{ Combustion equipment } & $\begin{array}{l}\text { Standby emergency } \\
\text { generators }\end{array}$ & 64,70 & Catalytic converter \\
\hline & $\begin{array}{l}\text { Standby emergency } \\
\text { generators }\end{array}$ & 67 & $\begin{array}{l}\text { Diesel particulate } \\
\text { filter }\end{array}$ \\
\hline & $\begin{array}{l}\text { Standby emergency } \\
\text { generators }\end{array}$ & Various $^{b}$ & None \\
\hline & $\begin{array}{l}\text { Standby emergency } \\
\text { generators }\end{array}$ & $J G I^{c}$ & None \\
\hline Gasoline dispensing & $\begin{array}{l}\text { Unleaded and E85 } \\
\text { fueling stations }\end{array}$ & 76 & Vapor recovery \\
\hline $\begin{array}{l}\text { Surface coating and } \\
\text { painting }\end{array}$ & Paint spray booth & 76,77 & Dry filter \\
\hline \multirow{2}{*}{$\begin{array}{l}\text { Surface preparation } \\
\text { and cleaning }\end{array}$} & Sandblast booth & 77 & Baghouse \\
\hline & Wipe-cleaning & Sitewide & None \\
\hline Miscellaneous & $\begin{array}{l}\text { Soil-vapor extraction } \\
\text { systems }\end{array}$ & $7 \mathrm{E}, 58$ & Activated carbon \\
\hline
\end{tabular}

a Bay Area Air Quality Management District

${ }^{b}$ Individual generators located at Buildings 2, 37, 48, 50A, 50B, 55, 62, 64, 66, 67, 70A, 72 , $74,75,77,84 \mathrm{~B}$, and 85 , plus four mobile locations

${ }^{\mathrm{C}}$ Two generators located at the Joint Genome Institute in Walnut Creek, California 


\subsubsection{Comprehensive Environmental Response, Compensation, and Liability Act}

The Comprehensive Environmental Response, Compensation, and Liability Act of 1980 (CERCLA) ${ }^{12}$ popularly called "Superfund" authorizes the U.S. EPA to manage the cleanup of abandoned or uncontrolled hazardous waste sites. According to CERCLA, the National Response Center must receive immediate notification of releases of hazardous substances in quantities that are equal to or greater than the Reportable Quantities of designated chemicals in the CERCLA regulation. In 2007 no releases occurred that were reportable under CERCLA, and Berkeley Lab conducted no remedial activities covered by CERCLA.

\subsubsection{Emergency Planning and Community Right-to-Know Act}

The EPCRA was passed in 1986 as Title III of the Superfund Amendments and Reauthorization Act (SARA) ${ }^{13}$ The Act establishes requirements for emergency planning, notification, and reporting. In California, the requirements of SARA Title III are incorporated into the state's Hazardous Materials Release Response Plans and Inventory Law. ${ }^{14}$ Berkeley Lab activities addressing these requirements are summarized in Sections 3.4.3.1 through 3.4.3.3.

\subsubsection{Toxic Release Inventory}

Under Executive Order $13148,{ }^{15}$ DOE is required to evaluate its facilities against the Toxic Release Inventory (TRI) reporting requirements of EPCRA without regard to SIC code. TRI reporting consists of two steps: Berkeley Lab determines chemical usage; and if threshold quantities are exceeded, DOE submits U.S. EPA Form R.

Berkeley Lab determined that no chemical usage in 2007 exceeded the TRI criterion of 4,536 kilograms $(\mathrm{kg})(10,000$ pounds [lb]) for a listed substance and that DOE was not required to submit a Form $\mathrm{R}$ on behalf of the
Laboratory. Table 3-4 shows the highest usage levels of the chemicals from the Laboratory's assessments over the past several years.

In 2002, U.S. EPA lowered reporting thresholds for 18 chemicals and chemical categories that meet the EPCRA Section 313 criteria for persistence, bioaccumulation, and toxicity (PBT). The thresholds were lowered to $45.5 \mathrm{~kg}$ (100 lb) for PBT chemicals and $4.5 \mathrm{~kg}(10 \mathrm{lb})$ for highly PBT chemicals. In May/June 2008, Berkeley Lab performed a sitewide survey on all 18 PBT chemicals and chemical categories for which reporting thresholds had been lowered. It was found that the PBT chemicals either were not present at Berkeley Lab or they were used in research experiments; hence the use of the PBT chemicals was exempt from reporting. Although the research exemption applies, for most of the PBT chemicals, the inventory of the PBT chemical is less than $1 \%$ of the U.S. EPA reporting threshold for usage.

Table 3-4 Trends in Highest Quantities of EPCRA ${ }^{a}$ Toxic Release Inventory Reporting (in Kilograms ${ }^{b}$ )

\begin{tabular}{|lrrrrr|}
\hline \multicolumn{1}{|c}{ Substance } & $\mathbf{2 0 0 3}$ & $\mathbf{2 0 0 4}$ & $\mathbf{2 0 0 5}$ & $\mathbf{2 0 0 6}$ & $\mathbf{2 0 0 7}$ \\
\hline Chlorofluorocarbons & 61 & 72 & 126 & 123 & 518 \\
Methanol & 228 & 206 & 129 & 165 & 63 \\
Nitric acid & 582 & 511 & 466 & 403 & 90 \\
Sodium Hydroxide ${ }^{\mathrm{c}}$ & $\mathrm{NA}^{\mathrm{d}}$ & $\mathrm{NA}$ & $\mathrm{NA}$ & $\mathrm{NA}$ & 914 \\
1,1,1-trichloroethane & 7 & $<1$ & 0 & $<1$ & $<1$ \\
\hline
\end{tabular}

${ }^{a}$ Emergency Planning and Community Right-to-Know Act

${ }^{\mathrm{b}} 1 \mathrm{~kg}=2.2 \mathrm{lb}$

${ }^{\mathrm{c}}$ Started tracking in 2007

${ }^{\mathrm{d}} \mathrm{NA}=$ not available

\subsubsection{Hazardous Materials Business Plan}

The City of Berkeley is the local administering agency for certain hazardous materials regulations falling under state law. Berkeley Lab voluntarily submits 
an annual Hazardous Materials Business Plan (HMBP) ${ }^{16}$ to the City of Berkeley, although the Laboratory as a federal facility is exempt from such regulations.

The 2007 HMBP included a list of all hazardous materials present in amounts exceeding the state's aggregate threshold quantities (i.e., 208 liters [L] [55 gallons (gal)] for liquids, $227 \mathrm{~kg}$ [500 lb] for solids, and 5.7 cubic meters [ $\left.\mathrm{m}^{3}\right]$ [200 cubic feet] for compressed gases) per building. The plan included a site map as well as summaries of emergency plans, procedures, and training. In addition, the HMBP included permit renewals for the underground storage tanks (USTs) and fixed treatment units (FTUs).

\subsubsection{Risk Management and Prevention Plan}

The City of Berkeley requires a Risk Management and Prevention Plan (RMPP) for operations using acutely hazardous materials above certain thresholds established in 40 CFR Part 355. Berkeley Lab does not have any operations that contain acutely hazardous materials above the threshold quantities, and therefore no RMPP is required for the site.

\subsubsection{Federal Insecticide, Fungicide, and Rodenticide Act}

Passed by Congress in 1972, the Federal Insecticide, Fungicide, and Rodenticide Act ${ }^{17}$ restricts the registration, sale, use, and disposal of pesticides. Pesticides, including insecticides and herbicides, are applied at the Berkeley Lab site by licensed contractors only. The Laboratory operates a composting program to minimize the use of herbicides and to reduce solid waste. The mulch generated from composting is used on-site for weed screening and landscaping where herbicides previously were applied. The end products from the chipper and mulcher program also are used to control erosion.

\subsubsection{Toxic Substances Control Act}

The objective of the Toxic Substances Control Act (TSCA) ${ }^{18}$ is to minimize the exposure of humans and the environment to chemicals found in manufacturing, processing, commercial distribution, and disposal activities. TSCA establishes a protocol for evaluating chemicals before they are introduced into the marketplace and controlling their use once they are approved for manufacturing. TSCA regulations are administered by the U.S. EPA.

Polychlorinated biphenyls (PCBs) are one of the principal substances at Berkeley Lab currently affected by the TSCA regulations. Since the TSCA program began, the Laboratory has removed all TSCA-regulated PCB transformers (PCB concentrations greater than 500 parts per million). The remaining equipment containing TSCA-regulated PCBs are four large lowvoltage capacitors. These capacitors remain in use, containing an estimated $170 \mathrm{~kg}$ (375 lb) of regulated PCB dielectric fluid. Because the small amount of PCBs is below reporting thresholds, the Laboratory is not required to prepare an annual PCB report for the U.S. EPA.

\subsubsection{Resource Conservation and Recovery Act}

The Resource Conservation and Recovery Act (RCRA) ${ }^{19}$ is an amendment to the earlier Solid Waste Disposal Act (SWDA) of 1965, and was enacted to create a management system that would regulate waste from "cradle to grave." In 1984, the Hazardous and Solid Wastes Amendments were added to the SWDA to reduce or eliminate the creation and disposal of hazardous wastes, and between 1984 and 1988, RCRA was expanded further to regulate USTs and other leaking waste-storage facilities. The primary goals of RCRA are:

- to protect the public from harm caused by waste disposal

- to encourage reuse, reduction, and recycling 
- to clean up spilled or improperly stored wastes

RCRA applies in two primary areas of Berkeley Lab operations: treatment and storage of hazardous waste (including the hazardous portion of mixed waste), and cleanup of historical releases of chemicals to the environment, thus by extension to operation of USTs.

\subsubsection{Hazardous Waste}

In California, DTSC administers the RCRA hazardous waste program. The California program incorporates the provisions of both the federal and state hazardous waste laws. ${ }^{20}$ The state program includes both permitting and enforcement elements. The state's permitting program for hazardous waste treatment and storage facilities consists of five tiers, shown in the following list in decreasing order of regulatory complexity:

- Full permit

- Standardized permit

- Permit-by-rule

- Conditional authorization

- Conditional exemption

The state oversees the "full permit" and the "standardized permit" tiers; the other three tiers have been delegated to the City of Berkeley for oversight under California's Certified Unified Program Agency program.

Berkeley Lab's HWHF operates under the "full permit" tier of the state's program. A full permit is also known as a RCRA Part B permit. The current permit for the HWHF ${ }^{21}$ was approved by DTSC on December 22, 2006, but was stayed pending an appeal by a local citizens' group. The appeal was resolved on July 31, 2007, allowing the renewed Part B permit to take effect. The permit authorizes storage and treatment of certain hazardous and mixed wastes at the HWHF. Authorized treatment includes neutralization, consolidation, solidification, filtration, precipitation, phase separation, ultraviolet (UV) ozone and UV peroxide oxidation, reduction of Class 1-3 oxidizers, air or steam stripping, absorption, adsorption, ion exchange, metallic exchange, evaporation, distillation electrowinning, rinsing of empty containers, mixing of multicomponent resins, and desensitization. Of these, only neutralization of mixed waste was performed in 2007.

Berkeley Lab has an additional hazardous waste permit to operate five FTUs. ${ }^{22}$ The type and location of each unit are listed in Table 3-5. These treatment units operate independently of the HWHF. Three of these FTUs are authorized to operate under the "conditional authorization" tier, while the

Table 3-5 Fixed Treatment Units Subject to the State's Tiered Permitting Program

\begin{tabular}{|ccllc|}
\hline FTU & Building & \multicolumn{1}{c}{ Treatment Description } & \multicolumn{1}{c}{ Permit Tier } & $\begin{array}{c}\text { Wastewater Volume } \\
\text { Treated } \\
\text { (Gallons) }\end{array}$ \\
\hline 002 & 25 & Metals precipitation and acid neutralization & Permit-by-rule & 5,930 \\
003 & 76 & Oil/water separation & Conditional authorization & 16,541 \\
004 & $70 \mathrm{~A} / 70 \mathrm{~F}$ & Acid neutralization & Conditional authorization & 931,950 \\
005 & 2 & Acid neutralization & Conditional authorization & 91,020 \\
006 & 77 & Metals precipitation and acid neutralization & Permit-by-rule & 31,537 \\
\hline
\end{tabular}


remaining two are authorized to operate under the "permit-by-rule" tier. The type of treatment determines which tier applies. The City of Berkeley requests renewal of this permit each year. The FTU permit was renewed in March 2007.

Berkeley Lab's waste management program also sends hazardous, universal, mixed, medical, and radioactive waste generated at the Laboratory off-site for disposal. Disposal of medical waste is managed in accordance with the state's Medical Waste Management Act $^{23}$ (see Section 3.4.6.2). Low-level radioactive waste is managed in accordance with DOE orders. Mixed waste is managed in accordance with the Mixed W aste Site Treatment Plan compliance order ${ }^{24}$ and is subject to both California EPA regulations and DOE Orders.

Waste management permits and regulations require Berkeley Lab to prepare several reports for the year:

- The Biennial Hazardous Waste Report, ${ }^{25}$ prepared for DTSC, contains facility treatment and disposal information for all hazardous waste activities (including the hazardous waste portion of mixed waste) at the HWHF during the reporting year.

- The Annual Report of Waste Generation and Pollution Prevention Progress, ${ }^{26}$ prepared for DOE, contains information on waste generated during the reporting year.

- Quarterly reports on the inventory of mixed waste more than one year old were submitted to DTSC until the RCRA Part B permit was renewed. These reports are no longer required by the permit.

In October 1995, DTSC approved the Laboratory's Mixed W aste Site Treatment Plan, ${ }^{27}$ which documents the procedures and conditions used by Berkeley Lab to manage its mixed-waste streams. The Laboratory prepares an annual report that quantifies the amount of mixed waste in storage at the end of the reporting period. This update is prepared in October for the previous fiscal year (FY), October 1 to September 30.

\subsubsection{Medical Waste}

Although not regulated under RCRA, medical waste is included here as hazardous waste which is also administered under the Berkeley Lab Waste Management Program.

In California, the state's Medical Waste Management $\mathrm{Act}^{28}$ contains requirements designed to ensure the proper storage, treatment, and disposal of medical waste. The state program is administered by the Department of Public Health (DPH), formerly known as the Department of Health Services.

Medical waste includes biohazardous waste (e.g., blood and bloodcontaminated materials) and "sharps" waste (e.g., needles) produced in the following activities:

- Research relevant to the diagnosis, treatment, or immunization of human beings or animals

- Diagnosis, treatment, or immunization of humans or animals

- Production of biological products used in medicine

The Laboratory generates medical waste at about 150 different locations distributed over 15 buildings, including 3 off-site buildings. Berkeley Lab does not treat any medical waste: it is treated at off-site vendor facilities, using either incineration or steam sterilization.

Berkeley Lab produced 15,447 kg (34,025 lb) of medical waste in 2007. Under the state's program, the Laboratory is considered a large-quantity generator because it generates more than $91 \mathrm{~kg}(200 \mathrm{lb})$ of medical waste each month. All large-quantity generators must register with the DPH and are subject to periodic inspections. DPH inspected the Berkeley Lab in 2007 and found four violations, one of which was contested. DPH also inspected the Potter Street facility and found three violations. 


\subsubsection{Corrective Action Program}

Berkeley Lab is currently in the final Corrective Measures Implementation (CMI) phase of the RCRA Corrective Action Program (CAP). The purpose of the CMI phase is to design, construct, operate, maintain, and monitor the corrective measures (cleanup activities) recommended by the Laboratory in the Corrective Measures Study (CMS) Report. ${ }^{29}$ These measures were approved by the DTSC, ${ }^{30}$ and are intended to reduce or eliminate the potentially adverse effects to human health or the environment caused by past releases of chemicals to soil and groundwater at Berkeley Lab.

The corrective measures required for soil have been completed. The corrective measures required for groundwater have been constructed and are operational, and consist of in situ soil flushing, groundwater capture, subsurface injection of Hydrogen Release Compound ${ }^{\circledR}$ (HRC), and monitored natural attenuation (MNA). In situ soil flushing consists of the injection of clean water into, and concurrent extraction of contaminated groundwater from, the subsurface. Groundwater capture involves extraction of groundwater in the downgradient portions of groundwater contaminant plumes to minimize further migration of the plumes. The extracted water from soil flushing and groundwater capture is cleaned on-site using granular activated carbon (GAC) treatment systems before being either reinjected for flushing or discharged to the sanitary sewer system. HRC is an environmentally safe polylactate ester formulate that is used to enhance the natural biodegradation of volatile organic compounds (VOCs) (enhanced bioremediation), and is injected at regular intervals into contaminant plume source areas. MNA refers to the reliance on natural attenuation processes within the context of a carefully controlled and monitored site cleanup approach to achieve site-specific remediation objectives. A more detailed description of the specific corrective measures pertaining to each of the groundwater contaminant plumes is given in Section 4.4.
As part of the CMI phase, the Laboratory has prepared a Soil Management Plan ${ }^{31}$ and a Groundwater Monitoring and Management Plan. ${ }^{32}$ These management plans describe the nature and extent of the contamination and the institutional controls required to reduce potential risk from exposure to the contaminants. The Groundwater Monitoring and Management Plan also provides the requirements for ongoing groundwater and surface water monitoring. These documents, as well as other RCRA CAP documents prepared by Berkeley Lab, are available for public review at the City of Berkeley main public library and at www.lbl.gov/ehs/erp/html/documents.shtml.

The Laboratory maintains a proactive approach in interacting with stakeholders in the RCRA CAP, including the DTSC, the Regional Water Quality Control Board (RWQCB), and the City of Berkeley.

\subsubsection{Executive Order 13423 (Strengthening Federal Environmental, Energy, and Transportation Management)}

In January 2007, United States Executive Order $13423^{33}$ replaced Executive Order 13101 (Greening the Government through Waste Prevention, Recycling, and Federal Acquisition). Like its predecessor, Executive Order 13423 seeks to integrate recycled materials into the procurement and acquisition process. Identified categories of products include the following:

- Electronic equipment

- Construction materials

- Landscape products

- Non-paper office products

- Paper products

- Park and recreation products

- Transportation products

- Vehicular products

- Miscellaneous products

- Bio-based content 
All federal agencies must procure only U.S. EPA-listed items with specified contents of recycled materials, unless a product is not available competitively within a reasonable time frame, does not meet appropriate performance standards, or is only available at an unreasonable price.

E.O. 13423 established environmental, energy, and transportation requirements for federal agencies, such as the DOE. DOE passed on these requirements to its contractors by adopting its DOE Order 450.1, Environmental Protection Program. As a DOE contractor, Berkeley Lab has had an affirmative procurement program ongoing since 1992. The Laboratory's Procurement staff searches for products made from recycled materials and works with other federal facilities to enhance their power to purchase environmentally sound products. The Laboratory has implemented a "stepped" program to ensure that only U.S. EPA-listed products manufactured from recycled materials will be purchased, as long as these materials are available at a reasonable cost and are compatible with the Laboratory's operating needs.

\subsubsection{Hazardous Waste Source Reduction and Management Review} Act

The California State Legislature passed the Hazardous Waste Source Reduction and Management Review Act ${ }^{34}$ in 1989. With an emphasis on minimizing waste and preventing pollution, the Act has the following goals:

- Reduce hazardous waste at its source

- Encourage recycling wherever source reduction is infeasible or impractical

- Manage hazardous waste in an environmentally safe manner and minimize present and future threats to health and the environment if it is infeasible to reduce or recycle

- Document hazardous waste management information and make that information available to state and local governments
Every four years, Berkeley Lab prepares a two-part report in compliance with this Act: the Source Reduction Evaluation Review Plan and Plan Summary ${ }^{35}$ and the Hazardous Waste Management Report Summary. ${ }^{36}$ The last report was compiled in 2007 and submitted to DOE Livermore Site Office as part of the DOE-wide report.

\subsubsection{Pollution Prevention Act of 1990}

The Pollution Prevention Act of $1990^{37}$ declares that source reduction is a national policy, and the Act directs U.S. EPA to study and encourage source reduction policies. Berkeley Lab's levels of pollution are below the de minimis thresholds identified in the Act, and therefore the Laboratory is not subject to its reporting requirements.

\subsubsection{Clean Water Act}

The CWA ${ }^{38}$ regulates the discharge of pollutants from both point and nonpoint sources to the waters of the United States, using various means; these include development of pollutant discharge standards and limitations and also a permit and licensing system to enforce the standards. California is authorized by U.S. EPA to administer the principal components of the federal water quality management program.

Additionally, the California Porter-Cologne Water Quality Control Act ${ }^{39}$ established a comprehensive statewide system for regulating water use. This 1969 act provides for a three-tiered system of regulatory oversight and enforcement: the State Water Resources Control Board (SWRCB), the nine RWQCBs, and local governments.

For the Berkeley Lab main site, the regional regulatory agency is the San Francisco Bay RWQCB. The local agencies are (1) the cities of Berkeley and Oakland for stormwater and (2) EBMUD for drinking-water supply and wastewater discharges. Central Contra Costa Sanitary District (CCCSD) is 
responsible for regulatory oversight of both wastewater and stormwater discharges from the JGI, which is in Walnut Creek.

\subsubsection{Wastewater}

The Laboratory has three wastewater discharge permits ${ }^{40}$ issued by EBMUD for the following activities:

- General sitewide wastewater discharge

- Treatment unit discharge of rinse water from the metal finishing operations in Buildings 25 and 77

- Treatment system discharge of groundwater from hydraugers and groundwater monitoring wells

In 2007, EBMUD renewed the wastewater discharge permits through 2012. The permits incorporate standard terms and conditions, individual discharge limits, and provisions, as well as monitoring and reporting requirements. Under each permit, Berkeley Lab submits periodic self-monitoring reports. The number of reports and their timing depend on the individual permit. No wastewater discharge limits were exceeded in 2007. (For more information regarding the results of the Laboratory's annual wastewater self-monitoring program, see Chapter 4.)

EBMUD inspects the Laboratory's sanitary sewer discharge activities without prior notice; the inspections include the collection and analysis of wastewater samples. The agency conducted inspections on eight separate occasions throughout the year. Table 3-2 lists these inspections, which were routine sample collections. No violations resulted from these inspections.

The EBMUD wastewater discharge permit for Buildings 25 and 77 requires that each facility maintain a Toxic Organics Management Plan and a Slug Discharge Plan. In 2007, the requirements of these two EBMUD plans were incorporated into each facility's Activity Hazard Document (AHD) for operations. Each AHD outlines facility management practices designed to eliminate the accidental release of toxic organics or any other pollutant to the sanitary sewers or external environment by emphasizing secondary containment and other appropriate spill prevention practices. The AHD for metal finishing areas at Buildings 25 and 77 also includes emergency response procedures.

To meet the requirements of EBMUD's Slug Discharge Plan, the Berkeley Lab maintains emergency response procedures for areas where spills are most likely to occur. Berkeley Lab has prepared operation-specific response procedures for the following activities: Buildings 25 and 77 metal finishing, Building 76 vehicle services, and Buildings 2 and $70 \mathrm{~A}$ rinse water treatment.

The Laboratory also holds a Class III Industrial User Permit ${ }^{41}$ issued by CCCSD for general wastewater discharged at the JGI in Walnut Creek. It was issued on December 3, 2004, and contains requirements for inspecting and reporting on operations, but no monitoring requirements.

\subsubsection{Stormwater}

Berkeley Lab's stormwater releases are permitted under the California-wide General Permit for Storm Water Associated with Industrial Activities (or General Permit). ${ }^{42}$ The General Permit is issued by the SWRCB but administered and enforced by the RWQCB and the City of Berkeley. Under this permit, the Laboratory has implemented a Storm Water Pollution Prevention Plan (SWPPP) ${ }^{43}$ and a Storm Water Monitoring Program (SWMP) ${ }^{44}$ The purpose of the SWPPP is to identify sources of pollution that could affect the quality of stormwater discharges, and to describe and ensure the implementation of practices to reduce pollutants in these discharges. The SWMP describes the rationale for sampling, sampling locations, and analytical parameters (radiological and nonradiological). Together, these documents represent the Laboratory's plan and procedures for identifying, monitoring, and reducing pollutants in its stormwater discharges. 
The General Permit requires submission of an annual report on stormwater activities by July 1 . Berkeley Lab transmitted its annual report to the RWQCB and the City of Berkeley in June. ${ }^{45}$ No regulatory concerns were raised by either agency regarding the annual report. (For a summary of the stormwater monitoring results, see Chapter 4.) No inspections of this program took place during the year.

Two incidents involving the discharge of sanitary sewer wastewater to the LBNL storm drain system, which flows to surface waters that lead to San Francisco Bay, occurred during the year. Both took place in June. Both were caused by localized blockages in the sanitary sewer lines. The California Office of Emergency Services and other local authorities were notified. DOE Occurrence Reports were also prepared for each incident. The blockages were promptly removed. Downstream visual observation and analytical sampling failed to detect elevated levels of pollutants, such as fecal coliform. Berkeley Lab also surveyed and cleaned, as needed, the remaining sanitary sewer lines on site in response to these two closely-timed incidents. More on each incident is discussed earlier in Section 3.3.3.

\subsubsection{Aboveground Storage Tanks}

Aboveground storage tanks (ASTs) also fall under the authority of the CWA. ${ }^{46}$ The CWA and the state's Aboveground Petroleum Storage Act ${ }^{47}$ outline the regulatory requirements for ASTs. Under the authority of the CWA, a Spill Prevention, Control, and Countermeasures (SPCC) Plan ${ }^{48}$ is required for petroleum-containing tanks, both aboveground and underground tanks. Berkeley Lab maintains an SPCC Plan with the goal of preventing and, if needed, mitigating spills or leaks from petroleum-containing tanks. ASTs are provided with secondary containment or spill kits to capture any potential leaks. The locations of the 30 ASTs are shown in Figure 3-2. In addition, at the JGI, a 15,142 L (4,000 gal) AST supports an engine generator; the JGI maintains an SPCC for this AST.
Nonpetroleum (i.e., chemical or hazardous) ASTs consist of FTU tanks, storage drums at Waste Accumulation Areas (WAAs), and storage drums at product distribution areas. FTU operators inspect FTU tanks each operating day. EH\&S staff inspect WAAs weekly. Product distribution areas containing petroleum and nonpetroleum drums are inspected by the Fire Department during routine inspections.

The E85-fuel dispensing-station tank (located at Building 76) provides a fuel mixture of $85 \%$ ethanol and 15\% unleaded gasoline. The station supports approximately 60 alternative-fuel vehicles. The use of $85 \%$-ethanol fuel is one of the Laboratory's strategies for reducing petroleum usage by its fleet of vehicles.

\subsubsection{Underground Storage Tanks}

In the early 1980s, California addressed the problem of groundwater contamination from leaking USTs through a rigorous regulatory and remediation program. ${ }^{49}$ The state program for USTs that contain hazardous materials addresses permitting, construction design, monitoring, record keeping, inspection, accidental releases, financial responsibility, and tank closure. The state's program satisfies the provisions of the federal RCRA requirements. ${ }^{50}$ The City of Berkeley is the local administering agency for UST regulations that apply to Berkeley Lab.

Two Berkeley Lab employees have passed the State of California exam to become a UST Designated Operator. These two employees are responsible for conducting monthly inspections of the UST systems; these inspections supplement the daily inspections conducted by other facility employees. The UST Designated Operators also provide annual training to the employees that conduct the daily UST inspections.

At the end of 2007, six permitted USTs were in operation at the Laboratory (see Table 3-6 and Figure 3-2). The tanks contain either diesel fuel or 
unleaded gasoline. The Laboratory has removed nine USTs since 1993 and properly closed each UST site.

On October 31st, leak-detection monitors were tested and recertified for all UST systems. During the recertification, the City of Berkeley inspected all six USTs and found no violations. On the same date, all product piping (pressure and suction) was pressure-tested for the UST systems. All piping passed the pressure tests. Also in October, every spill bucket at the fill port of each UST was tested for leaks. All spill buckets were found free of leaks.

\subsubsection{Safe Drinking Water Act}

The Safe Drinking Water Act ${ }^{51}$ and amendments established requirements to protect underground sources of drinking water and set primary drinkingwater standards for public water systems. Berkeley Lab has no drinking-water wells on-site. The drinking water provided to the site comes from the EBMUD supply and distribution system. EBMUD water is tested for compliance with state and federal drinking-water standards. Berkeley Lab has taken measures to protect its distribution system for its drinking-water supply by installing backflow-prevention devices on main supply lines throughout the site.

EBMUD currently uses chloramine for disinfection of the drinking-water supply. Although chloramine improves the water supply for human consumption, it is toxic to fish and other aquatic organisms. To prevent toxic effects to organisms involved in laboratory research, researchers have instituted measures to neutralize the chloramine to provide water in which these organisms can safely exist.

Additionally, to prevent toxic effects to organisms living in neighboring creeks, Berkeley Lab has programs to prevent drinking water from being discharged to the Laboratory's storm drains. When responding to waterline breaks and when testing and flushing fire hydrants, the Facilities Division and Fire Department neutralize the chloramine before the water reaches a storm drain.

Table 3-6 Underground Storage Tank Operating Permits from the City of Berkeley

\begin{tabular}{|c|c|c|c|c|c|c|}
\hline $\begin{array}{c}\text { Registration } \\
\text { Tank ID } \\
\text { Number }\end{array}$ & Building & Stored Material & \multicolumn{2}{|c|}{$\begin{array}{c}\text { Capacity } \\
\text { in Liters (Gallons) }\end{array}$} & Construction & Year Installed \\
\hline \multicolumn{7}{|c|}{ Fiberglass tanks, double-walled } \\
\hline $2-1$ & 2 & Diesel & 15,200 & $(4,000)$ & Fiberglass & 1988 \\
\hline $2-2$ & 2 & Diesel & 3,800 & $(1,000)$ & Fiberglass & 1988 \\
\hline $85-1$ & 85 & Diesel & 9,500 & $(2,500)$ & Fiberglass & 1995 \\
\hline \multicolumn{7}{|c|}{ Steel tanks, double-walled, with fiberglass-reinforced plastic corrosion protection } \\
\hline $55-1$ & 55 & Diesel & 3,800 & $(1,000)$ & Glasteel & 1986 \\
\hline $76-1$ & 76 & Unleaded gasoline & 38,000 & $(10,000)$ & Glasteel & 1990 \\
\hline $76-2$ & 76 & Diesel & 38,000 & $(10,000)$ & Glasteel & 1990 \\
\hline
\end{tabular}




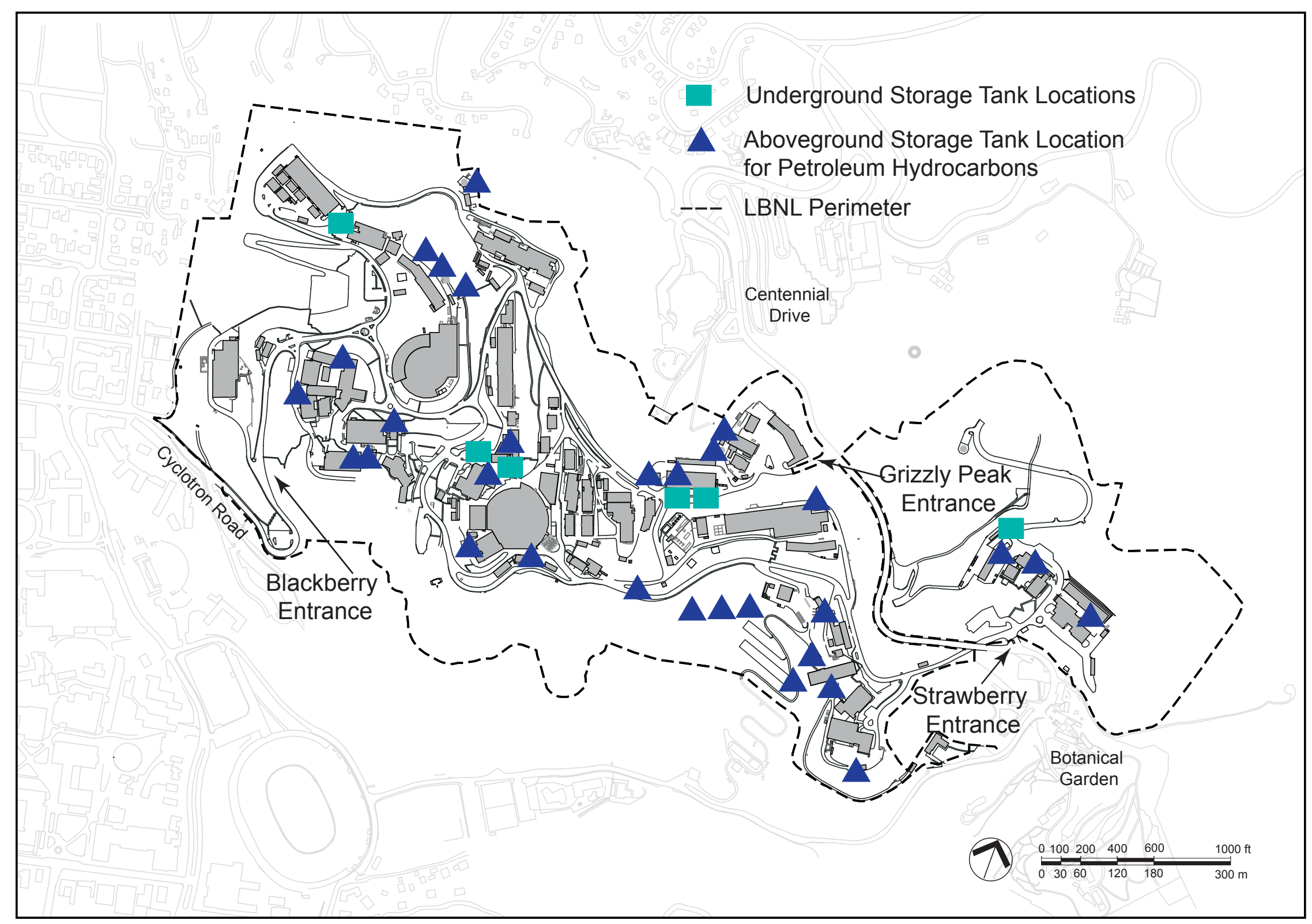

Figure 3-2 Aboveground and Underground Storage Tank Locations at the End of Calendar Year 2007 


\subsubsection{National Environmental Policy Act and California Environmental Quality Act}

Laboratory staff provides information to enable DOE and the Regents of the University of California to determine whether proposed actions at Berkeley Lab will have a significant effect on the environment as required by the National Environmental Policy Act of 1969 (NEPA) ${ }^{52}$ and the California Environmental Quality Act of 1970 (CEQA). ${ }^{53}$

DOE and the Regents conducted the following major NEPA and CEQA reviews of proposed projects at Berkeley Lab in 2007:

- Finding of No Significant Impact for the Construction and Operation of the Guest House Building

- Regental Certification of the Final Environmental Impact Report (EIR) and Regental Adoption of the 2006 Long Range Development Plan

- Final Environmental Impact Report and Certification of the Demolition of Building 51 and the Bevatron

- Draft EIR circulated for the Helios Energy Research Facility

- Draft EIR circulated for the Computational Research and Theory Facility

\subsubsection{Federal Endangered Species Act}

The Federal Endangered Species Act ${ }^{54}$ requires that activities taking place at Berkeley Lab on federally controlled property, or using federal permission or funding, undergo a screening process or the NEPA process to determine whether federally listed or proposed species may be present or affected by the action. No compliance activities were required in 2007.

\subsubsection{California Endangered Species Act}

The California Endangered Species Act ${ }^{55}$ requires that activities taking place at Berkeley Lab on UC Regents land, or using UC Regents or state permission or funding, undergo a screening process or the CEQA process to determine whether state-listed or proposed species may be present or affected by the action. No compliance activities were required in 2007 .

\subsubsection{National Historic Preservation Act}

The National Historic Preservation Act ${ }^{56}$ provides for a National Register of Historic Places, which lists buildings, structures, sites, objects, and districts that possess historic, architectural, engineering, archaeological, or cultural significance. Berkeley Lab currently is undergoing a sitewide inventory with a qualified historian in consultation with the State Historic Preservation Officer to determine which assets at Berkeley Lab are eligible for listing on the National Register and to comply with the Act.

In 2007, the process that culminated in the UC Regents' approval of the Final Environmental Impact Report for the Demolition of Building 51 and the Bevatron included a review to ensure compliance with Section 106 of the National Historic Preservation Act.

In November 2007, a Memorandum of Agreement between DOE and the California State Historic Preservation Officer was signed regarding the project to remove the Super Hilac in Building 71. The agreement required the preparation of an Historic American Engineering Record to document the Super Hilac before it was removed.

\subsubsection{Migratory Bird Treaty Act}

The Migratory Bird Treaty Act ${ }^{57}$ legislates that actions and projects undertaken at Berkeley Lab must undergo appropriate NEPA and CEQA review, which includes assessment of biological impacts, to determine whether species subject to the provisions of the Migratory Bird Treaty Act would be affected. No compliance activities were required in 2007. 


\subsection{PERFORMANCE MEASURES}

Since 1994, Berkeley Lab, DOE, and the University of California's Office of the President (UCOP) have used a system to annually measure the effectiveness of the Laboratory's performance, including the performance of its environmental programs. These performance measures have been integrated directly into the operating contract for Berkeley Lab. Possible ratings include letter grades ranging from $\mathrm{A}+$ to $\mathrm{F}$. Berkeley Lab has consistently received high marks from both DOE and UCOP since the inception of environmental performance measures 13 years ago.

For FY 2007 (October 1 to September 30), there were two environmental measures. Berkeley Lab achieved a $\mathrm{B}+$ rating for the environmental protection measure. The score for this measure is based on weighting factors applied to environmental incidents, that is, regulatory violations and hazardous materials releases. Note that not all occurrence reports or incidents are necessarily recorded for performance measure purposes, and that performance measurement is based on the fiscal year, not the calendar year. Four incidents were recorded; all were minor regulatory issues resulting from a sewer system overflow, two inspections conducted by the State of California, DTSC, and one inspection by DPH:

- In June 2007, wastewater from a sanitary sewer system overflowed from a sewer manhole in the building 75 area. Environmental regulations required reporting the release to the California Office of Emergency Services, the Regional Water Quality Control Board, and the City of Berkeley.

- Berkeley Lab received a written notice of violation from DPH for a medical waste inspection in April 2007. The inspection reports are for the Potter Street facility and the main site. Of the total of seven violations issued, five minor violations were recorded for performance measure purposes, four accepted by LBNL and one contested.
- In March 2007, Berkeley Lab entered into a consent order with DTSC concerning several findings from inspections in 2003, 2004, and 2005. Three items stored in waste generator areas in excess of one year and one instance of transporting hazardous waste from LBNL to Building 903 in a salvage hopper were identified that had not previously been scored under the contract performance measures.

- The final report from the May 2006 DTSC inspection of the HWHF was received in March 2007. The two minor labeling violations were corrected at the time of the inspection.

Berkeley Lab achieved an A rating for the second measure, the meeting of all EMS goals, that is, process milestones and number of projects. The Laboratory accomplished the four EMS process milestones established for FY 2007:

1. Review environmental aspects and impacts

2. Determine the set of environmental aspects

3. Revise existing Environmental Management Programs as needed, or develop new ones

4. Complete internal annual assessment

In addition, several EMS projects were completed, resulting in the following:

- Reduction in diesel emissions

- Reduction in petroleum use

- Increase in purchases of products with recycled content

- Installation of wastewater treatment system

- LEED Gold certification of the Molecular Foundry

For more information on environmental performance measures, go to Berkeley Lab's Office of Institutional Assurance home page at http://www.lbl.gov/DIR/OIA/OCA/contract-performance/index.html. 


\section{Environmental Monitoring}

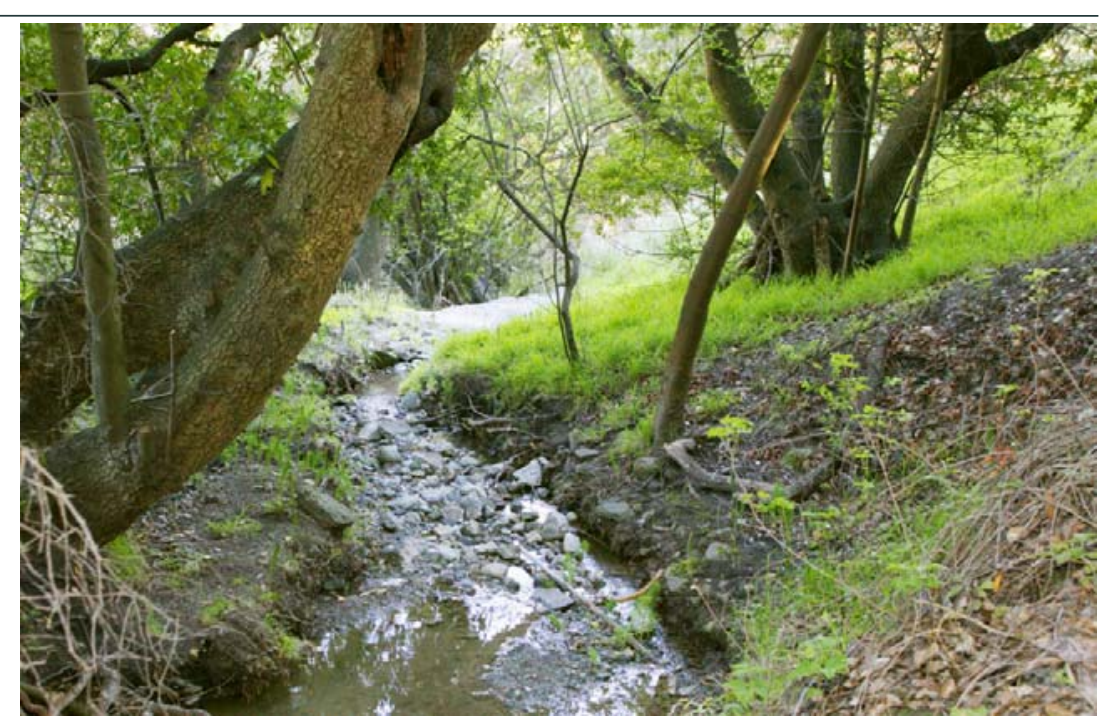

Chicken Creek on the Berkeley Lab site

4.2.1 Exhaust-Emissions Monitoring Results

4.2.2 Ambient-Air Monitoring Results

SURFACEWATERANDWASTEWATER

4.3.1 Surface Water Program

4.3.1.1 Rainwater Sampling Results

4.3.1.2 Creeks Sampling Results 
4.3.2.2 Building 25 Photo Fabrication Shop Wastewater

4.3.2.3 Building 77 Ultra-High Vacuum Cleaning Facility Wastewater

4.3.2.4 Treated Hydrauger and Extraction Well Discharge

4.4.1 Groundwater Monitoring Results

4.4.2 Groundwater Contaminant Plumes

4.4.2.1 Old Town VOC Plume_Building 7 Lobe

4-17

4.4.2.2 Old Town VOC Plume_Building 25A Lobe 4-17

4.4.2.3 Old Toun VOC Plume_Building 52 Lobe 4-17

4.4.2.4 Building 51/64 VOC Plume

4-18

4.4.2.5 Building 51L VOC Plume

4-18

4.4.2.6 Building 71B VOC Plume

4-18

4.4.2.7 Building 69A VOC Plume

4-19

4.4.2.8 Building 76 VOC Plume

4-19

4.4.2.9 Tritium Plume

4-19

4.4.2.10 Petroleum Hydrocarbon Plumes

4-19

4.4.3 Treatment Systems

4-19

4.5.1 Soil Sampling Results

4-19

4.5.2 Sediment Sampling Results

4-21 


\subsection{INTRODUCTION}

The Berkeley Lab environmental monitoring program assesses whether the Laboratory's emissions are impacting the health of the public or the environment. The program is important for environmental stewardship and for demonstrating compliance with requirements imposed by federal, state, and local agencies. The program also confirms adherence to $\mathrm{DOE}$ environmental protection policies and supports environmental management decisions.

This chapter presents summaries of the 2007 monitoring results for the following categories:

- $\quad$ Stack and ambient air

- Surface water and wastewater

- Groundwater

- Soil and sediment

- Vegetation and foodstuffs

- Penetrating radiation

A comprehensive Environmental Monitoring Plan ${ }^{1}$ prepared by Berkeley Lab provides the basis and current scope for each of these monitoring programs. This plan is updated regularly; the most recent revision was completed in February 2006.

All of the individual sample results except for groundwater are presented in Volume II of this Site Environmental Report. Additional details on groundwater investigations and results are included in Environmental Restoration Program reports, which are available at the City of Berkeley main public library and at http://www.lbl.gov/ehs/erp.

\subsection{AIR QUALITY}

Lawrence Berkeley National Laboratory's air monitoring program is designed to measure the impacts from radiological air emissions. The program meets the U.S. EPA and DOE requirements, which are contained in the following references:

- 40 CFR Part 61, Subpart H (National Emission Standards for Hazardous Air Pollutants, or NESHAP) ${ }^{2}$

- DOE Order 5400.5 (Radiation Protection of the Public and the Environment) ${ }^{3}$

This program consists of two elements: exhaust-emissions monitoring and ambient-air surveillance. Exhaust-emissions monitoring measures contaminants in building exhaust systems (e.g., stacks). Ambient-air surveillance measures contaminants in the outdoor environment. The number and placement of monitoring stations, as well as the substances collected and their collection frequencies, are routinely reviewed to address changes in Laboratory operations or external requirements.

\subsubsection{Exhaust-Emissions Monitoring Results}

Berkeley Lab uses various radionuclides in its radiochemical and biomedical research programs. Charged-particle accelerators also generate radioactive materials. These operations result in small amounts of airborne radionuclides, which are typically emitted through building exhaust systems.

Berkeley Lab must evaluate the potential for radionuclide emissions from laboratories where radionuclides are used. If the potential emissions exceed the U.S. EPA-approved threshold, the Laboratory must measure emissions by sampling or monitoring stacks through which emissions are released. Sampling means collecting radionuclides on a filter and analyzing the filters at an analytical laboratory; monitoring means continuously measuring radionuclides in real time. 
The Laboratory measures stack emissions in accordance with an approach approved by U.S. EPA Region 9 (Table 4-1). Based on this approach, only periodic or quarterly (Category 3) sampling is required because all sources have potential doses that are less than $0.001 \mathrm{mSv} / \mathrm{yr}(0.1 \mathrm{mrem} / \mathrm{yr})$. However, Berkeley Lab may monitor or sample some stacks more frequently than required by U.S. EPA. Exercising this option, Berkeley Lab collected monthly samples from five stacks and performed real-time monitoring at four stacks (one of which was also sampled monthly) in addition to collecting samples quarterly from four stacks. Sampling and monitoring locations are shown in Figure 4-1.

Stack exhaust samples were analyzed for five radiological parameters: gross alpha, gross beta, carbon-14, iodine-125, and tritium. Real-time stack monitoring systems measured for alpha emitters and positron emitters. In 2007, the positron emitter fluorine-18 (half-life of 1.8 hours) was the predominant radionuclide emitted and accounted for about $67 \%$ of the Table 4-1 U.S. EPA-Approved Radionuclide Emissions Measurement Approach

\begin{tabular}{|c|c|c|}
\hline Category & $\begin{array}{l}\text { Annual Effective Dose } \\
\text { Equivalent }^{\mathrm{a}} \text { (mSv/yr) }^{\mathrm{b}}\end{array}$ & Requirements \\
\hline $\begin{array}{c}\text { Noncomplian } \\
\mathrm{t}\end{array}$ & $A E D E \geq 0.1$ & $\begin{array}{l}\text { Reduction or relocation of the source } \\
\text { and reevaluation before authorization }\end{array}$ \\
\hline 1 & $0.1>$ AEDE $\geq 0.01$ & $\begin{array}{l}\text { Continuous sampling with weekly } \\
\text { collection and real-time monitoring for } \\
\text { short-lived radionuclides }\end{array}$ \\
\hline 2 & $0.01>$ AEDE $\geq 0.001$ & $\begin{array}{l}\text { Continuous sampling with monthly } \\
\text { collection or real-time monitoring for } \\
\text { short-lived radionuclides }\end{array}$ \\
\hline 3 & $0.001>\mathrm{AEDE} \geq 0.0001$ & Periodic sampling $25 \%$ of the year \\
\hline 4 & $0.0001>\mathrm{AEDE}$ & $\begin{array}{l}\text { Potential dose evaluation before } \\
\text { project starts and when project } \\
\text { changes; no sampling or monitoring } \\
\text { required }\end{array}$ \\
\hline
\end{tabular}

\footnotetext{
${ }^{a}$ Abbreviated as AEDE
}

${ }^{\mathrm{b}} 1 \mathrm{mSv}=100 \mathrm{mrem}$ emitted activity. The Building 56 accelerator was the main source of fluorine18 emissions $\left(1.96 \times 10^{11}\right.$ becquerels $[\mathrm{Bq}]$ [5.30 curies (Ci)]). Additional details on stack emissions are available in the Laboratory's annual Radionuclide Air Emission Report, submitted to U.S. EPA (at http://www.lbl.gov/ehs/esg, under "Available Documents"). (For information on the projected dose from all radionuclide emissions, see Chapter 5.)

In addition to air emissions from exhaust systems, Berkeley Lab also collected and analyzed tritium levels in rainwater that drained down the inside of stacks associated with the former National Tritium Labeling Facility (NTLF). In the first half of 2007, the average concentration of tritium in drain water collected, analyzed, and disposed of was $1.36 \times 10^{5} \mathrm{~Bq} / \mathrm{L}\left(3.68 \times 10^{6}\right.$ picocuries/L $[\mathrm{pCi} / \mathrm{L}])$ and the maximum was $3.00 \times 10^{5} \mathrm{~Bq} / \mathrm{L}\left(8.11 \times 10^{6} \mathrm{pCi} / \mathrm{L}\right)$. In accordance with an internal authorization, the stack drain water was sent to the HWHF for disposal as low-level radioactive waste. In 2007, the rooms associated with the former NTLF were decontaminated and the exhaust systems were removed, so in future years there will be no stack drain water to sample.

\subsubsection{Ambient-Air Monitoring Results}

The objective of the ambient-air monitoring program is to determine the environmental levels of two general classes of radionuclides, alpha and beta emitters. Ambient-air monitoring for tritium was eliminated in early 2005 as a result of the shutdown of the NTLF.

The network consists of three sites on the main grounds of the Laboratory and a fourth off-site location. All locations were chosen based on historical wind patterns and current Laboratory activities. One of the sites also includes a collocated sampler for quality control (QC) purposes. Figure 4-2 shows the sampling locations. 


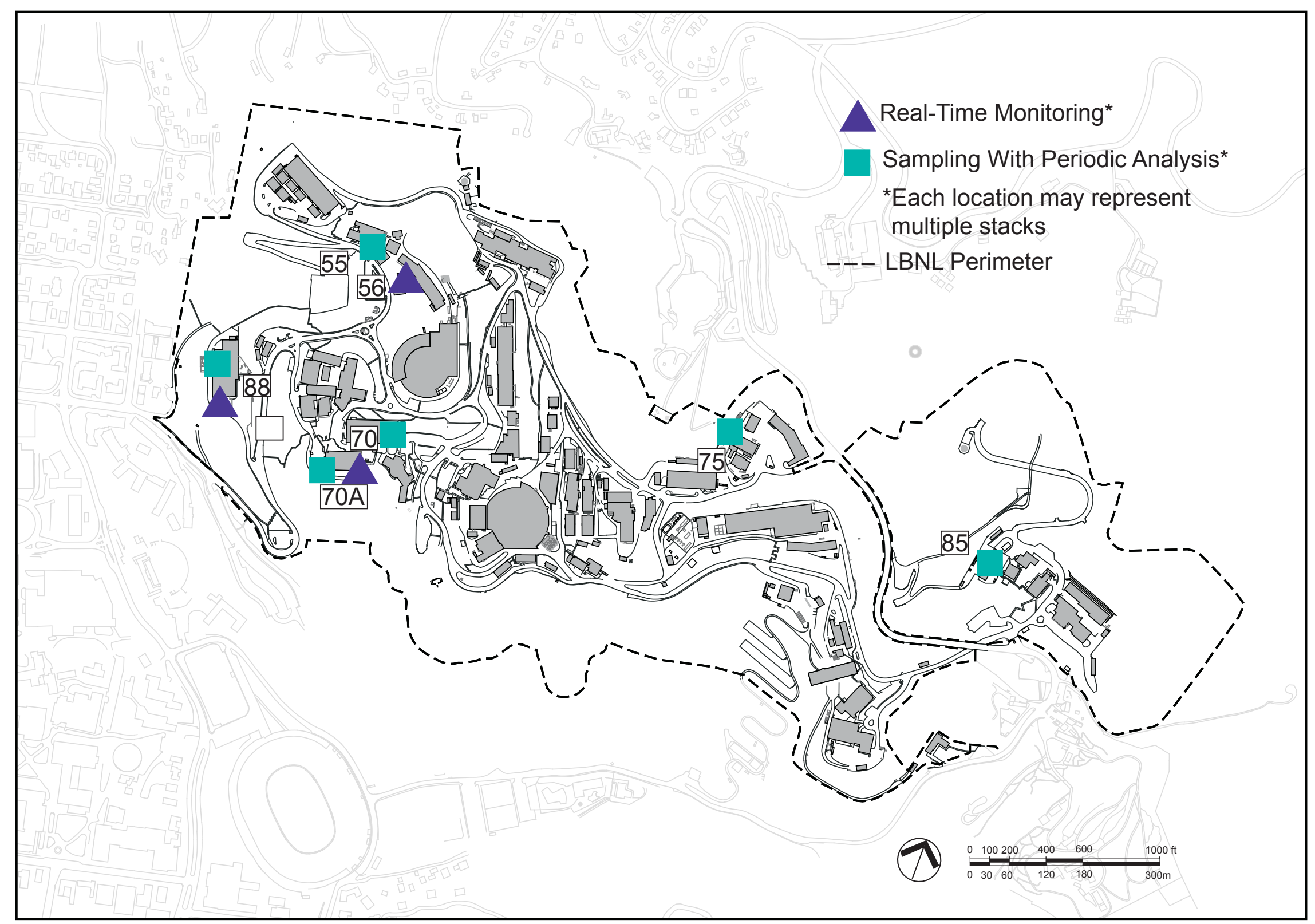

Figure 4-1 Locations of Building Exhaust Sampling and Monitoring 


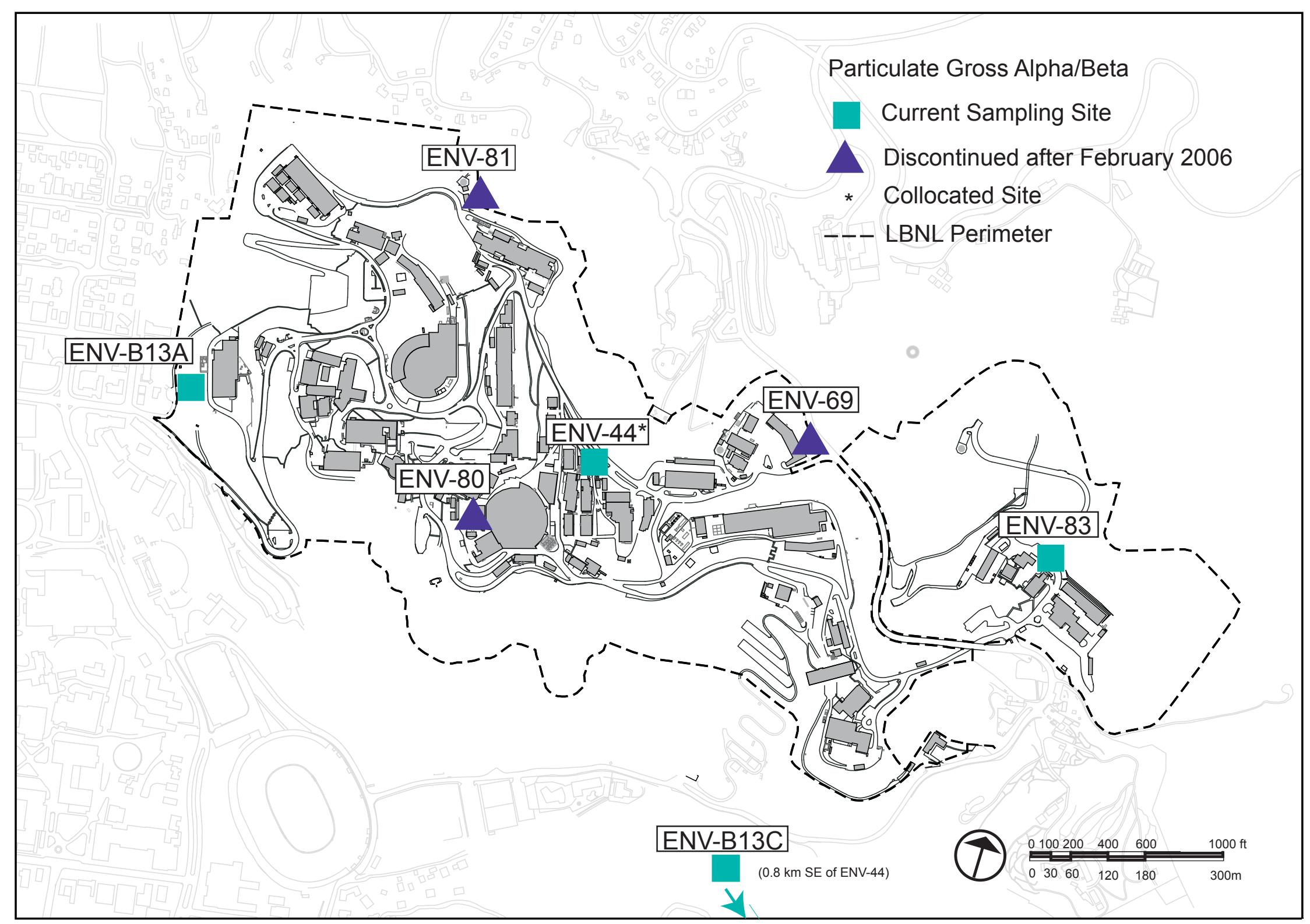

Figure 4-2 Ambient-Air Monitoring Network Sampling Locations 
Table 4-2 summarizes gross alpha and beta sample results from the sampling network. While DOE Order $5400.5^{4}$ does not provide ambient-air thresholds for either parameter, all results were near or below the analytical detection limits. This observation is consistent with results from prior years across the network.

Table 4-2 Summary of Alpha and Beta Radiation Results for Ambient-Air Samples

\begin{tabular}{|llcccc|}
\hline Analyte & Station ID & $\begin{array}{c}\text { Number of } \\
\text { Samples }\end{array}$ & $\begin{array}{c}\text { Mean } \\
(\mathrm{Bq} / \mathrm{m})^{\mathrm{a}}\end{array}$ & $\begin{array}{c}\text { Median } \\
\left(\mathrm{Bq} / \mathrm{m}^{3}\right)\end{array}$ & $\begin{array}{c}\text { Maximum } \\
\left(\mathrm{Bq} / \mathrm{m}^{3}\right)\end{array}$ \\
\hline Alpha & ENV-B13A & 12 & $4.9 \times 10^{-5}$ & $5.1 \times 10^{-5}$ & $1.2 \times 10^{-4}$ \\
& ENV- B13C & 12 & $4.9 \times 10^{-5}$ & $4.7 \times 10^{-5}$ & $1.2 \times 10^{-4}$ \\
& ENV-44 & 12 & $4.2 \times 10^{-5}$ & $4.4 \times 10^{-5}$ & $8.5 \times 10^{-5}$ \\
& ENV-83 & 12 & $5.1 \times 10^{-5}$ & $5.1 \times 10^{-5}$ & $1.1 \times 10^{-4}$ \\
\hline Beta & ENV-B13A & 12 & $4.6 \times 10^{-4}$ & $4.0 \times 10^{-4}$ & $9.9 \times 10^{-4}$ \\
& ENV-B13C & 12 & $5.0 \times 10^{-4}$ & $4.2 \times 10^{-4}$ & $1.3 \times 10^{-3}$ \\
& ENV-44 & 12 & $4.9 \times 10^{-4}$ & $3.8 \times 10^{-4}$ & $1.2 \times 10^{-3}$ \\
& ENV-83 & 12 & $5.0 \times 10^{-4}$ & $3.9 \times 10^{-4}$ & $1.2 \times 10^{-3}$ \\
\hline
\end{tabular}

${ }^{a} \mathrm{~Bq}=27 \mathrm{pCi}$

${ }^{\mathrm{b}}$ Station ENV-B13C provides local background data for alpha and beta radiation in ambient-air particulate.

\subsection{SURFACE WATER AND WASTEWATER}

This section summarizes the monitoring results for surface water (rainwater, creeks, and stormwater), and wastewater.

\subsubsection{Surface Water Program}

Berkeley Lab lies within the Blackberry Canyon and Strawberry Canyon subwatersheds of the Strawberry Creek watershed. There are two main creeks in these watersheds, the South Fork of Strawberry Creek (in Strawberry Canyon) and the North Fork of Strawberry Creek (in Blackberry
Canyon). Both creeks join below the Laboratory on the UC Berkeley campus.

Surface water monitoring for 2007 included rainwater, creeks, and stormwater. Rainwater and creeks are monitored primarily for alpha and beta emitters and tritium, based on DOE Order $5400.5,{ }^{5}$ which prescribes monitoring requirements for radioisotopes. Creek water is also monitored for nonradiological analytes in an ongoing effort to characterize and manage the Laboratory's overall impact on the environment. Stormwater monitoring is a condition of the California-wide General Permit for Storm Water Associated with Industrial Activity (or General Permit) ${ }^{6}$ and includes monitoring for metals and other constituents.

Although Laboratory surface waters are not used as a public drinking water supply, Berkeley Lab takes the conservative approach of evaluating surface water results against drinking-water standards. The federal and state maximum contaminant levels for alpha and beta radioactivity in drinking water are $0.6 \mathrm{~Bq} / \mathrm{L}(15 \mathrm{pCi} / \mathrm{L})$ and $1.9 \mathrm{~Bq} / \mathrm{L}(50 \mathrm{pCi} / \mathrm{L})$, respectively. ${ }^{7,}$ The federal and state limit for tritium in drinking water is $740 \mathrm{~Bq} / \mathrm{L}(20,000$ pCi/L. $)^{9},{ }^{10}$ The Laboratory also uses the water quality objectives stated in the Water Quality Control Plan (Basin Plan) for the San Francisco Bay Basin ${ }^{11}$ for comparison purposes.

All surface water samples were analyzed by state-certified laboratories.

\subsubsection{Rainwater Sampling Results}

Measurable rainfall occurred during January through May and October through December. During the months that were part of the 2006-2007 rainfall year, a sample of the composite rainfall for the month was collected near Building 75 at ENV-75 (see Figure 4-3) and analyzed for gross alpha, gross beta, and tritium activity. Prior to the start of the next rainfall year, the sampling location was moved to the site of the meteorological tower and the 


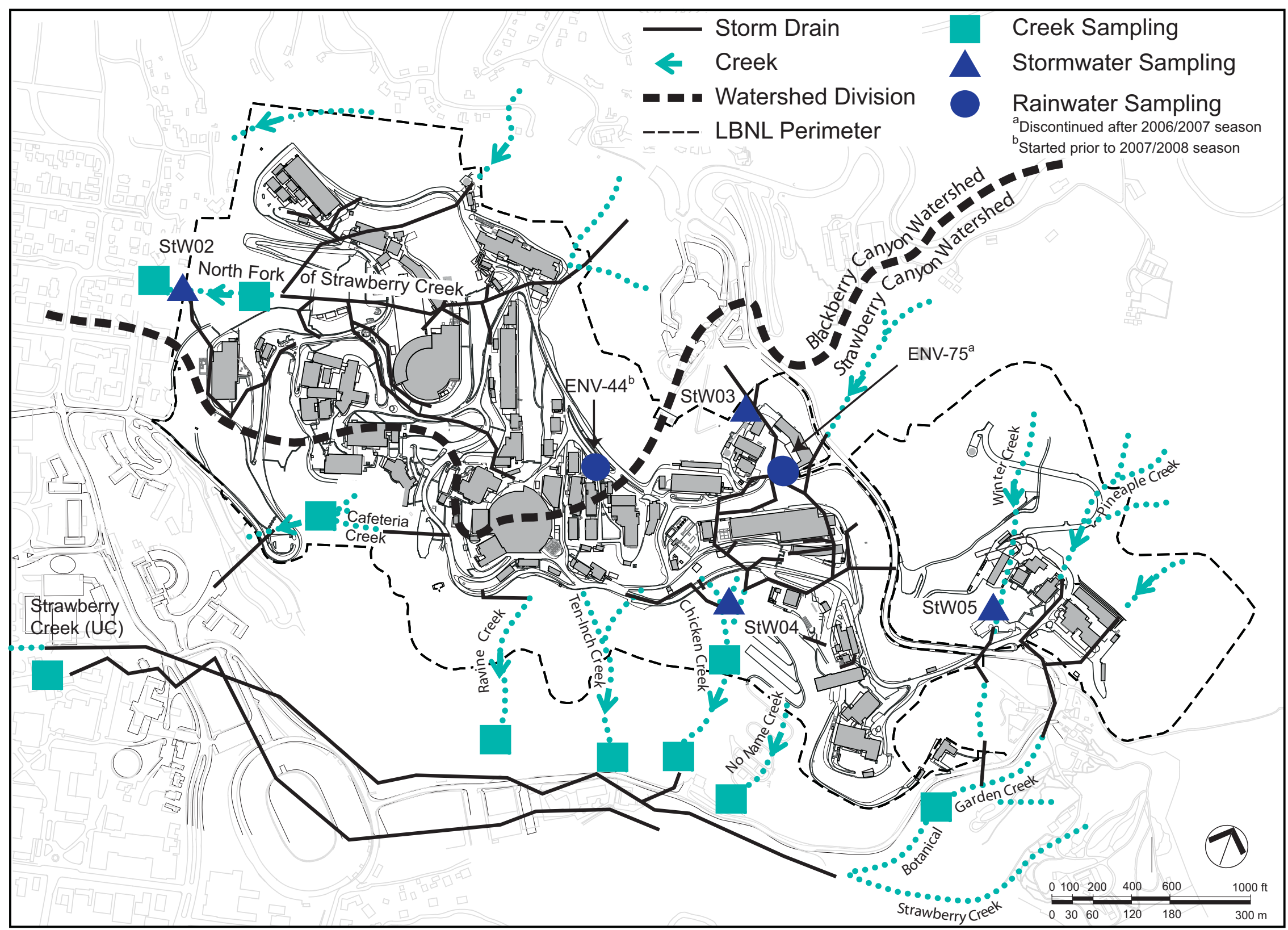

Figure 4-3 Creek, Rainwater, and Stormwater Sampling Locations 
ENV-44 ambient air sampling stations. This location is more representative of the precipitation falling on the entire site and reflects the diminished emphasis on tritium monitoring since the closure of the NTLF. Monthly composite sample results from both locations were consistent with historical values and were below drinking-water standards. All sample results for alpha and beta were below or near detection limits. No tritium activity was detected in any of the samples.

\subsubsection{Creeks Sampling Results}

The flow in many of the creeks of the Strawberry Creek watershed varies in intensity throughout the year. To track any seasonal variation in water quality, a sample is collected quarterly from each of three creeks: Chicken Creek, the North Fork of Strawberry Creek, and Strawberry Creek (UC). Samples are analyzed for gross alpha, gross beta, and tritium radiological activity, as well as for mercury.

Samples are also collected at a reduced frequency from a second set of creek locations. One set of samples was collected in 2007 at locations in Chicken Creek and the North Fork of Strawberry Creek, plus five other creeks: Botanical Garden Creek, Cafeteria Creek, No Name Creek, Ravine Creek, and Ten-Inch Creek. The samples were analyzed for tritium and numerous metals and volatile organic compounds (VOCs). Figure 4-3 shows all creek sampling locations.

No VOCs were detected in any samples collected during the year. Similarly, most metals were not detectable in any samples. A very low concentration of mercury was detected in the third quarter (i.e., August) sample collected in the North Fork of Strawberry Creek. However, the result was not confirmed by the quality assurance split sample at this same location, which had no detectable levels of mercury. The metals that were detected were limited to arsenic, barium, selenium, vanadium, and zinc. Their concentrations were (1) within historical levels for the Laboratory, (2) well below the water quality objectives listed in the Basin Plan, ${ }^{12}$ and (3) well below the drinking-water standard. The few times (approximately 15\% of the time) that gross alpha, gross beta, or tritium radioactivity was detected, the activities were only slightly above analytical detection limits and well below the drinking-water standard.

\subsubsection{Stormwater Sampling Results}

Surface runoff from Berkeley Lab can be substantial because of the site's hillside location, the amount of paved or covered surface, the moderate annual rainfall, and the intensity of some rainfall events. All stormwater runoff from the site is routed through its stormwater drainage system to either the South Fork or the North Fork of Strawberry Creek.

Under the terms of California's General Permit, sampling must take place at least twice each stormwater year (i.e., October to September) under specific conditions. Berkeley Lab's SWMP ${ }^{13}$ describes the rationale for sampling, sampling locations, and analytical parameters (radiological and nonradiological). See Figure 4-3 for the locations of the four sampling sites. This permit also requires visual observation of one storm each month and visual observation of authorized and unauthorized nonstormwater discharges once each quarter. Stormwater sampling in 2007, which actually spanned the 2006-2007 and 2007-2008 rainfall years, included the following parameters:

- General indicator parameters: chemical oxygen demand (COD), $\mathrm{pH}$, specific conductance, and total suspended solids (TSS)

- Metals and minerals: aluminum, iron, magnesium, mercury, and zinc

- Nutrients: nitrogen and nitrate

- Petroleum hydrocarbons: oil and grease (in lieu of total organic carbon [TOC]), and total petroleum hydrocarbons (TPH) (as diesel range organics)

- Radioactivity: alpha, beta, and tritium. 
Only oil and grease, $\mathrm{pH}$, specific conductance, and total suspended solids were explicitly required by the General Permit.

The list of parameters sampled is only a partial listing of potential surface water quality objectives considered by the Basin Plan, yet one that is appropriate for the activities at the Berkeley Lab site. This list assesses the overall state of water quality using a broad range of measures. The General Permit refers to 40 CFR Subchapter N standards for industrial source categories, 40 CFR Part 117 and 40 CFR Part 302 regulations for reportable quantities of hazardous substances, and the Basin Plan for the San Francisco Bay Basin.

Sampling results for the year were below detectable concentrations (or activities) for mercury, oil and grease, and tritium across the network. When detectable results for other parameters were observed, the concentrations varied by location and by stormwater sampling event. But in all cases the results were (1) within historical levels for the Laboratory, (2) consistent with urban background levels, (3) within the objectives of the Basin Plan, and (4) well below drinking-water standards.

\subsubsection{Wastewater Discharge Program}

The Laboratory's sanitary sewer system is based on gravity flow and discharges through one of two monitoring stations, Hearst or Strawberry (see Figure 4-4).

- Hearst Station, located at the head of Hearst Avenue below the western edge of Berkeley Lab, monitors discharges from the western and northern portions of the site. The monitoring site is located at a point immediately before the connection of the Laboratory's sanitary sewer system with the City of Berkeley's sewer main.

- Strawberry Station is located next to Centennial Drive in Strawberry Canyon and monitors discharges from the eastern and southern parts of the Laboratory. Downstream from the monitoring station, the discharge system first ties into University-owned piping and then into the City of Berkeley system. Because of the design of the network, the Strawberry Monitoring Station also receives effluent from several UC Berkeley campus facilities that are located above the Laboratory and are separate from the main UC Berkeley campus: the Lawrence Hall of Science, Space Sciences Laboratory, Mathematical Sciences Research Institute, Animal Research Facility, and Botanical Garden.

Self-monitoring of wastewater discharges within Berkeley Lab also occurs at wastewater treatment systems (Fixed Treatment Units) located at Buildings 25 and 77 and at groundwater treatment systems, according to the terms of their respective EBMUD permits. ${ }^{14}$ EBMUD is the local Publicly Owned Treatment Works that regulates all industrial and sanitary discharges to its treatment facilities.

Berkeley Lab has three wastewater discharge permits issued by EBMUD: one for general sitewide discharges, one for the metal finishing operations found in Buildings 25 and 77, and one for the discharge of treated groundwater from hydraugers.

The Laboratory's wastewater discharge permits require periodic monitoring for various parameters as specified by EBMUD. In addition, EBMUD performs unannounced monitoring of wastewater discharges. For 2007, no changes in permit requirements occurred, and all sampling results for the three permits were below discharge limits.

\subsubsection{Hearst and Strawberry Sewer Outfalls}

Nonradiological monitoring of sitewide samples includes analyses for $\mathrm{pH}$, total identifiable chlorinated hydrocarbons (TICH), TSS, and COD, with additional analyses for metals. Also, total flow is measured and recorded. In 


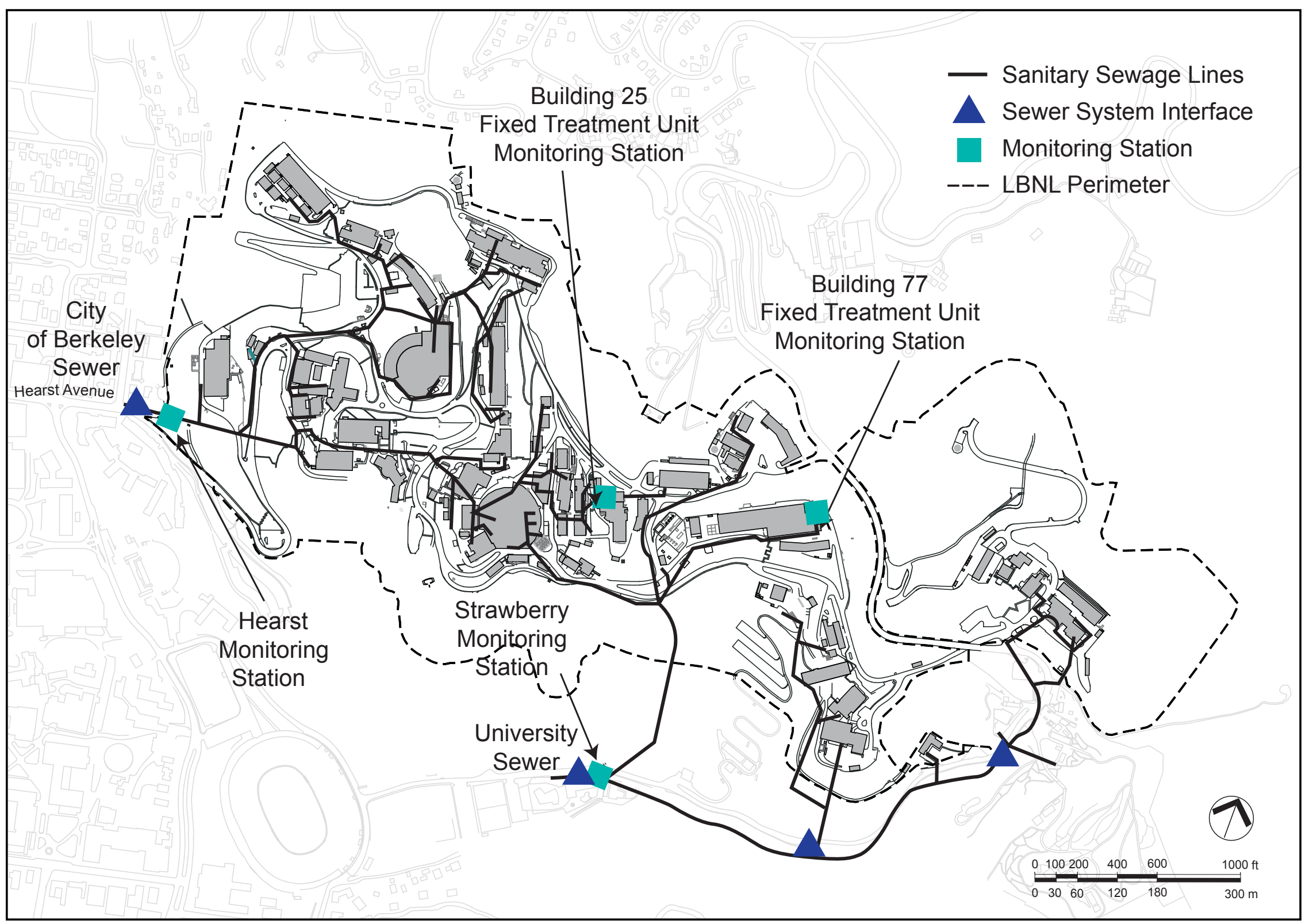

Figure 4-4 Sanitary Sewer System 
2007, Berkeley Lab discharged approximately 11.5 million gallons through Hearst Sewer and 35.8 million gallons through Strawberry Sewer.

Radiological monitoring is required by DOE Order $5400.5^{15}$ and guidance, ${ }^{16}$ but the monitoring also ensures compliance with radiological limits under the California Code of Regulations, ${ }^{17}$ cited in the EBMUD wastewater discharge permit. ${ }^{18}$ California regulations now incorporate by reference the applicable federal regulations ${ }^{19}$ and associated discharge limits.

Analyses are performed by a state-certified external laboratory. Results are compared against the discharge limits for each parameter given in the permits, and self-monitoring reports are submitted to EBMUD in compliance with permit requirements. Annually, Berkeley Lab submits a certification to EBMUD that the Laboratory's discharge is in compliance with the permit's radioactive limits.

\subsection{Nonradiological Monitoring Results}

Berkeley Lab collected two samples from both the Hearst and Strawberry outfalls as part of self-monitoring during 2007. All results were well within discharge limits, as were all measurements made by EBMUD in its five independent sampling events.

No chlorinated hydrocarbons were detected except chloroform (which is present in EBMUD supply water). According to the permit, the $\mathrm{pH}$ level must be equal to or greater than 5.5; all results were well above this value. TSS and COD have no discharge limits and are measured to determine wastewater strength, which forms the basis for the costs charged by EBMUD to the Laboratory for wastewater treatment.

\subsection{Radiological Monitoring Results}

The Hearst and Strawberry sewer outfalls are continuously sampled at halfhour intervals using automatic equipment. Every four weeks, composite samples are collected and submitted to a state-certified laboratory for analysis of gross alpha radiation, gross beta radiation, iodine-125, tritium, phosphorus-32, sulfur-35, and carbon-14. Periodically, split samples are analyzed for additional QC purposes.

The federal ${ }^{20}$ and state ${ }^{21}$ regulatory limits for radioisotopes are based on total amounts released per year. For tritium, this limit is $1.9 \times 10^{11} \mathrm{~Bq}(5 \mathrm{Ci})$; and for carbon-14 the limit is $3.7 \times 10^{10} \mathrm{~Bq}(1 \mathrm{Ci})$. The annual limit for all other radioisotopes is a combined $3.7 \times 10^{10} \mathrm{~Bq}(1 \mathrm{Ci})$.

All results for carbon-14, iodine-125, phosphorus-32, and tritium samples collected at the Hearst and Strawberry Monitoring Stations were below minimum detectable activity (MDA).

Positive results for gross alpha, gross beta, and sulfur- 35 were found. Of the twenty-six samples taken for gross alpha, three samples were found positive slightly above the MDA. However, all three results were less than two times the MDA. The highest gross alpha result was $0.089 \mathrm{~Bq}(2.4 \mathrm{pCi} / \mathrm{L})$, which is below the federal and state requirements for drinking water. For gross beta results, the highest result was $0.79 \mathrm{~Bq}(21 \mathrm{pCi} / \mathrm{L})$, which is below the federal and state requirements for drinking water. For sulfur-35, one sample was found positive slightly above the MDA. At $0.39 \mathrm{~Bq}(11 \mathrm{pCi} / \mathrm{L})$, this was less than two times the MDA and is below the federal and state requirements for drinking water.

The estimates for the annual discharges of tritium and of carbon-14 in wastewater were $0.0 \mathrm{~Bq}(0.0 \mathrm{Ci})$; and the total discharge of other radioisotopes was $6.32 \times 10^{7} \mathrm{~Bq}(0.0017 \mathrm{Ci})$. The estimate for the annual discharge of all other radioisotopes together were approximately $0.17 \%$ of their limit.

\subsubsection{Building 25 Photo Fabrication Shop Wastewater}

The Photo Fabrication Shop in Building 25 manufactures electronic circuit boards and screen-print nomenclature on panels, and the shop performs 
chemical milling, to support the needs of Berkeley Lab research and operations activities. Wastewater containing metals and acids from these activities is routed to an FTU before discharge to the sanitary sewer. The Building 25 FTU treats wastewater in batches rather than continuously.

All sampling performed by Berkeley Lab and EBMUD-two selfmonitorings and two sampling events by EBMUD—yielded daily maximum and monthly average results well below EBMUD discharge limits. ${ }^{22}$

\subsubsection{Building 77 Ultra-High Vacuum Cleaning Facility Wastewater}

The Ultra-High Vacuum Cleaning Facility (UHVCF) at Building 77 cleans various types of metal parts used in research and support activities at Berkeley Lab. Cleaning activities include passivating, acid and alkaline cleaning, and ultrasonic cleaning. Acid and alkaline rinse waters that contain metals from UHVCF operations are routed to a nearby $227 \mathrm{~L} /$ minute $(\mathrm{L} / \mathrm{min})(60 \mathrm{gal} / \mathrm{min})$ FTU.

All sampling performed by Berkeley Lab and EBMUD-three selfmonitorings and two sampling events by EBMUD—yielded results well within permitted limits.

The Building 77 EBMUD permit is currently combined with the Building 25 permit. According to the current EBMUD permit, at Building 77, Berkeley Lab samples three times per year for $\mathrm{pH}$ and metals; at Building 25 , the Laboratory samples twice per year. Instead of monitoring for chlorinated hydrocarbons, the Laboratory submits a Total Toxic Organics Compliance Report twice per year; it certifies that Buildings 25 and 77 are not discharging chlorinated hydrocarbons or other toxic organic compounds to the FTU which then discharges to the sanitary sewer.

\subsubsection{Treated Hydrauger and Extraction Well Discharge}

Since 1993, EBMUD has permitted Berkeley Lab to discharge treated groundwater to the sanitary sewer. The treatment process consists of passing the contaminated groundwater through a two-stage carbon-drum adsorption system.

The EBMUD permit ${ }^{23}$ allows for discharge of treated groundwater from certain hydrauger (subsurface drain) treatment systems and extraction wells, and also from well sampling and development activities. Samples of the treated water are collected monthly and analyzed for VOCs using U.S. EPAapproved methodologies to document that discharge limits have not been exceeded. All treated groundwater discharged under the permit is routed through the Hearst Sewer. One of the conditions for this discharge is the submission of a semiannual report that provides information on the volumes treated and discharged, as well as analytical results for samples collected each quarter from the treated water. (For further discussion of groundwater monitoring and treatment, see Section 4.4.)

\subsection{GROUNDWATER}

This section reviews the Berkeley Lab groundwater monitoring program (emphasizing 2007 results) and provides a summary discussion of site groundwater contaminant plumes and the corrective measures applied to each of those plumes. More detailed information on the program is provided in the Environmental Restoration Program Quarterly Progress Reports, which contain all site groundwater monitoring data, site maps showing monitoring well locations and contaminant concentrations, and graphs showing changes in contaminant concentrations over time. These reports are available for public review at the City of Berkeley main public library and at http://www.lbl.gov/ehs/erp/html/documents.shtml. 
Berkeley Lab is currently in the CMI phase of the RCRA CAP. The objectives of groundwater monitoring during this phase are to: (1) evaluate the continued effectiveness of the corrective measures that have been implemented for cleanup of contaminated groundwater; (2) document that site groundwater plumes are stable or attenuating and are not migrating offsite; and (3) monitor progress toward attaining the long-term goal of restoring all groundwater at the Laboratory to drinking-water standards, if practicable. Although drinking-water standards are a long-term goal, it should be noted that groundwater at Berkeley Lab is not used for domestic, irrigation, or industrial purposes and drinking water is supplied by EBMUD.

\subsubsection{Groundwater Monitoring Results}

The groundwater monitoring network at Berkeley Lab consists of more than 180 wells, with 16 of the wells located close to the site boundary and 1 well located offsite (see Figure 4-5). The Laboratory's groundwater monitoring wells are sampled for VOCs, metals, and/or tritium in accordance with a schedule approved by the RWQCB. Selected wells are also monitored for other potential contaminants.

Except for a single well, MWP-7, in which trichloroethylene (TCE) was detected at a concentration well below the drinking-water standard, ${ }^{24}$ no tritium or VOCs were detected in any of the 17 perimeter or off-site wells in 2007. Sitewide VOC and tritium results are discussed in detail in Section 4.4.2.

The only metals detected in 2007 at concentrations above both drinking-water standards and the statistically estimated Berkeley Lab background levels ${ }^{25}$ were arsenic and selenium (in one well each). No plumes are associated with these metals, and the metals are likely to be naturally occurring. Elevated arsenic concentrations, for example, may be attributed to the relatively high natural concentration of this metal in certain sedimentary rock types at the Laboratory. In addition, molybdenum, which has no drinking-water standard, was detected above the background level in seven wells.

\subsubsection{Groundwater Contaminant Plumes}

VOC Plumes: Based on groundwater monitoring results, six principal VOC groundwater contaminant plumes have been identified at Berkeley Lab (Old Town, Building 51/64, Building 51L, Building 71B, Building 69A, and Building 76 plumes). The primary contaminants associated with these plumes are halogenated VOCs that were used as cleaning solvents and their associated degradation products. Past releases associated with use of these solvents were the source of the groundwater contamination that currently underlies some of the site. Over the past several decades, the Laboratory has improved control systems and practices to prevent spills and unwanted releases.

Concentrations of VOCs exceeded drinking water standards in all six VOC plumes in 2007. Localized areas of VOC-contaminated groundwater are also present in the Building 75/77 area and near Building 77. Concentrations of VOCs exceeded drinking water standards in the Building 75/77 area in 2007, but not in the area near Building 77 .

Tritium Plume: A plume of tritium-contaminated groundwater extends southward from the Building 75 area. Concentrations of tritium have been below the drinking water standard of $740 \mathrm{~Bq} / \mathrm{L}(20,000 \mathrm{pCi} / \mathrm{L})^{26,27}$ in all wells since February 2005. The source of the contamination was the former NTLF, which ceased operation in 2001.

Petroleum Hydrocarbon Plumes: Two petroleum hydrocarbon plumes associated with former USTs are present at the site. One is located at Building 74 and the other near Building 6. Concentrations of petroleum hydrocarbon constituents have been below drinking water standards in all wells monitoring these two plumes since 1994.

The locations of the plumes and the extent of groundwater with contaminant concentrations exceeding the drinking water standard in September 2007 are shown on Figure 4-6. The plumes are discussed in more detail in the following subsections. 


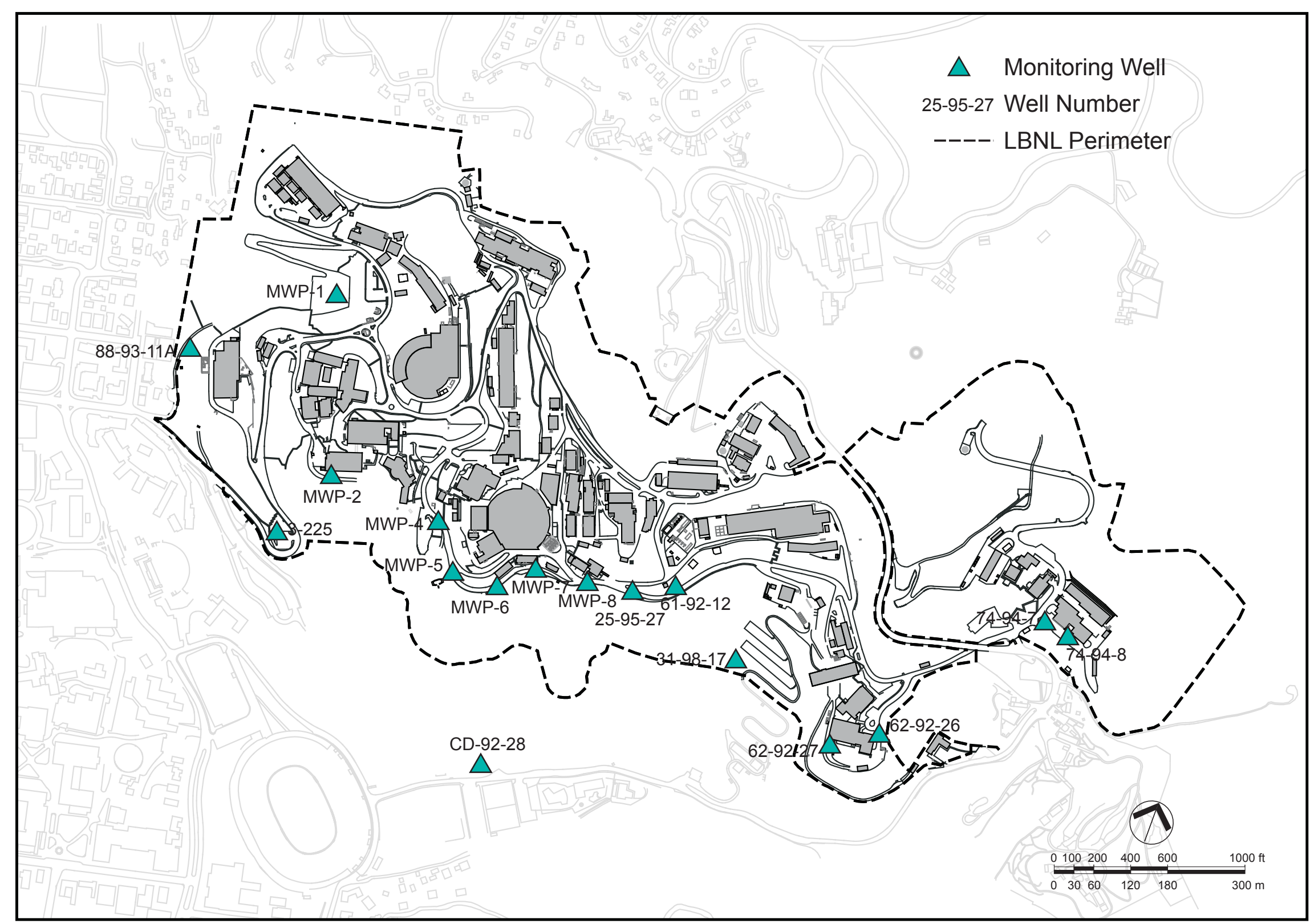

Figure 4-5 Approximate Locations of Monitoring Wells Closest to the Berkeley Lab Property Line 


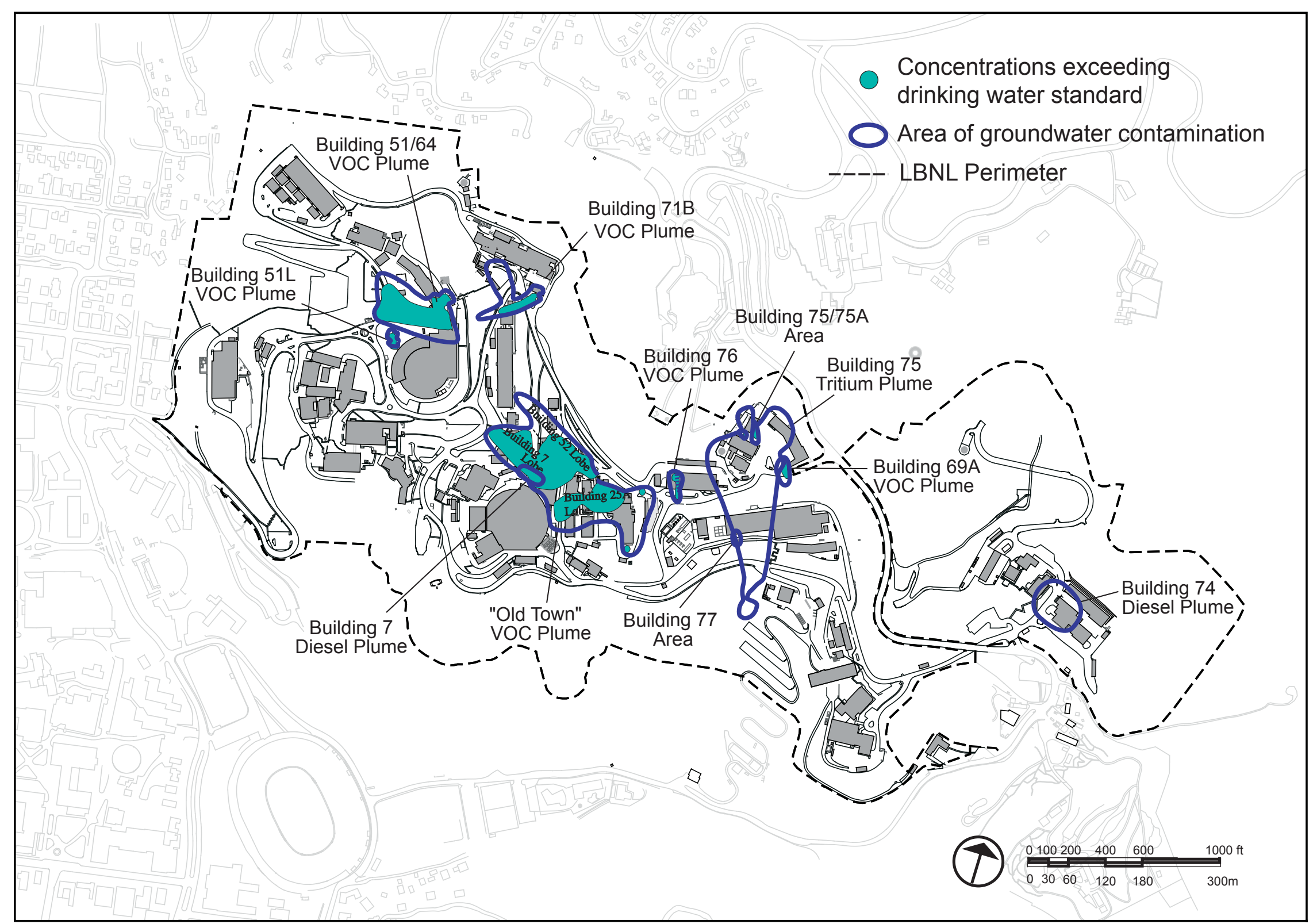

Figure 4-6 Locations of Plumes and Extent of Groundwater Contamination Above Drinking-Water Standards (September 2007) 


\subsubsection{Old Town VOC Plume-Building 7 Lobe}

The Old Town VOC plume is a broad, multi-lobed plume that underlies much of the central portion of Berkeley Lab known as "Old Town." The geometry and distribution of chemicals in the plume indicate that it consists of three coalescing lobes (Building 7, Building 25A, and Building 52 lobes) that were originally discrete plumes derived from distinct sources.

The Building 7 lobe extends northwestward from the northwest corner of Building 7 to the parking area downslope from Building 58. The principal constituents of the Building 7 lobe are tetrachloroethylene (PCE) and carbon tetrachloride, and their associated degradation products (e.g., TCE; 1,1dichloroethene (DCE); cis-1,2-DCE; and vinyl chloride).

A number of interim corrective measures were instituted in prior years for the Building 7 lobe, including excavation of contaminated soil from the source area, removal of a sump that was the source of the groundwater contamination, and installation of several groundwater extraction trenches to control plume migration.

The final corrective measures for the Building 7 lobe consisted of excavation and off-site disposal of additional contaminated soil remaining in the source area, in situ soil flushing and groundwater capture, and MNA. Excavation of the source area soil was completed in 2006. The in situ soil-flushing and groundwater capture system consists of three groundwater extraction trenches and numerous groundwater extraction and injection wells. This system is designed to flush contaminants from the subsurface and control the migration of contaminated groundwater.

The source removal, together with in situ soil flushing and groundwater capture, has significantly reduced VOC concentrations through much of the Building 7 lobe area, with the annual average concentration of total VOCs in source and core area wells declining from approximately 20,000 micrograms per liter ( $\mu \mathrm{g} / \mathrm{L})$ to less than 2,000 $\mu \mathrm{g} / \mathrm{L}$ in 2007 . The maximum concentration of total VOCs detected in 2007 was $20,259 \mu \mathrm{g} / \mathrm{L}$, which primarily consisted of PCE $(13,800 \mu \mathrm{g} / \mathrm{L})$ and TCE $(5,990 \mu \mathrm{g} / \mathrm{L})$. This sample was collected from a well that is screened entirely in a low-permeability zone in the core of the plume, and is not representative of overall Old Town plume contamination.

\subsubsection{Old Town VOC Plume-Building 25A Lobe}

The Building 25A lobe of the Old Town VOC plume encompasses two subplumes of groundwater contamination. The main Building 25A subplume extends from the western portion of Building $25 \mathrm{~A}$ westwards to the eastern edge of Building 6. The Building 25 subplume is located south of Building 25 . The principal constituents of the Building 25A subplume are TCE and its degradation products (e.g., 1,1-DCE and cis-1,2-DCE). The principal constituents of the Building 25 subplume are TCE and carbon tetrachloride at low concentrations.

The final corrective measure for the Building 25A lobe consists of in situ soil flushing. Since flushing was started in 2002, the annual average concentration of total VOCs in the Building 25A subplume source and core area wells has declined from approximately $300 \mu \mathrm{g} / \mathrm{L}$ to less than $50 \mu \mathrm{g} / \mathrm{L}$ in 2007. Significant declines in the concentrations of VOCs have also been observed in the Building 25 subplume since the initiation of soil flushing in the subplume source area in April 2006. Except for carbon tetrachloride $(0.51 \mu \mathrm{g} / \mathrm{L})$, which slightly exceeded the drinking-water standard of $0.5 \mu \mathrm{g} / \mathrm{L}$, concentrations of VOCs in groundwater samples collected south of Building 25 remained below the drinking-water standard in 2007.

\subsubsection{Old Town VOC Plume-Building 52 Lobe}

The Building 52 lobe of the Old Town VOC plume extends northwest from the area east of Building 52 to the east edge of Building 46, where the contaminated groundwater is captured by a subdrain that was installed in the 
1950s as a landslide mitigation measure. The principal lobe constituents are PCE and carbon tetrachloride, and their degradation products (e.g., TCE; 1,1DCE; cis-1,2-DCE; and chloroform)

The final corrective measures for the Building 52 lobe consist of in situ soil flushing and the continued capture of groundwater at the Building 46 subdrain. Since flushing was started in 2003, the annual average concentration of total VOCs in the Building 52 lobe source and core area wells has declined from more than $100 \mu \mathrm{g} / \mathrm{L}$ to less than $5 \mu \mathrm{g} / \mathrm{L}$ in 2007 , with concentrations declining to less than drinking-water standards throughout the entire lobe area.

\subsubsection{Building 51/64 VOC Plume}

The Building 51/64 VOC plume extends south and west from the southeast corner of Building 64 beneath the former location of Building 51B. The principal plume constituents are 1,1,1-trichloroethane (TCA), TCE, PCE, and their associated degradation products (e.g., 1,1-DCE; 1,1-dichloroethane (DCA); cis-1,2-DCE; and vinyl chloride).

In 2000 , contaminated soil was excavated from the source area of the plume as an interim corrective measure. The final corrective measures for the Building 51/64 VOC plume consist of in situ soil flushing, MNA, and the continued collection and treatment of water from the Building 51 subdrain system. In addition, HRC is being injected into the subsurface in the downgradient plume area. Since flushing was started in 2003, the annual average concentration of total VOCs in source and core area wells has declined from more than $4,000 \mu \mathrm{g} / \mathrm{L}$ to less than $200 \mu \mathrm{g} / \mathrm{L}$ in 2007. The maximum concentration of total halogenated VOCs (primarily 1,1-DCA) detected in 2007 was $6,452 \mu \mathrm{g} / \mathrm{L}$ in a groundwater sample from a multiport well in the source area. This well was constructed with short, approximately 1 $\mathrm{ft}$, screened intervals to target specific permeable zones within the bedrock, and therefore it is not representative of the water-bearing unit as a whole.
Excluding the multiport well, the maximum total VOC concentration in the source area has declined from more than $700,000 \mu \mathrm{g} / \mathrm{L}$ prior to excavation of the source area in 2000 to less than $500 \mu \mathrm{g} / \mathrm{L}$ at the end of 2007 .

\subsubsection{Building 51L VOC Plume}

The Building 51L VOC plume is located beneath the area where Building 51L was formerly located. The principal plume constituents are TCE, PCE, and their associated degradation products (e.g., cis-1,2-DCE; trans-1,2-DCE; and vinyl chloride). The maximum concentration of total VOCs (primarily TCE) detected in 2007 was $2,302 \mu \mathrm{g} / \mathrm{L}$.

The final corrective measure for the Building 51L VOC plume was excavation and offsite disposal of the contaminated source area soil. The corrective measure was completed at the end of 2006.

\subsubsection{Building 71B VOC Plume}

The Building 71B VOC plume extends southwest from Building 71B towards the Building 51/64 area. The principal plume constituents are TCE and PCE, and their associated degradation products (e.g., cis-1,2-DCE). Between 2000 and 2004, highly contaminated soil was excavated from the plume source area as an interim corrective measure.

The final corrective measures for the Building 71B VOC plume consist of in situ soil flushing with the injection of HRC and continued collection and treatment of contaminated effluent from the hydraugers that drain groundwater from the slope west of Building 46A. Since flushing was started in 2004, the annual average concentration of total VOCs in source area wells has declined from more than $300 \mu \mathrm{g} / \mathrm{L}$ to approximately $20 \mu \mathrm{g} / \mathrm{L}$ in 2007 . Concentrations of total VOCs have declined from a maximum of more than 6,000 $\mu \mathrm{g} / \mathrm{L}$ initially to less than $100 \mu \mathrm{g} / \mathrm{L}$ at the end of 2007 . 


\subsubsection{Building 69A VOC Plume}

The Building 69A VOC plume is located west of Building 69A. The principal plume constituents are cis-1,2-DCE and vinyl chloride.

The final corrective measure for the Building 69A VOC Plume is MNA. In addition, HRC is being injected into the subsurface to enhance the natural degradation processes. The maximum concentration of total VOCs (primarily cis-1,2-DCE) detected in 2007 was $21 \mu \mathrm{g} / \mathrm{L}$. Since HRC injection was started, the concentrations of cis-1,2-DCE and vinyl chloride in wells monitoring the plume have generally declined.

\subsubsection{Building 76 VOC Plume}

The Building 76 VOC plume extends approximately 100 feet southwards from the motor-pool area on the south side of Building 76 . The principal plume constituent is TCE and its degradation products (e.g., cis-1,2-DCE). The maximum concentration of total VOCs detected in groundwater samples collected in 2007 was $21 \mu \mathrm{g} / \mathrm{L}$. No corrective measures are required for the Building 76 plume.

\subsubsection{Tritium Plume}

The Building 75 tritium plume extends southwards from Building 75 toward Chicken Creek and covers the areas of Buildings 69, 75, 75A, 75B, and 77. In addition, low concentrations of tritium have been detected in monitoring wells in the Building $71 \mathrm{~B}$ area. The source of the tritium was the former NTLF at Building 75. The maximum concentration of tritium detected in groundwater in 2007 was $577 \mathrm{~Bq} / \mathrm{L}(15,600 \mathrm{pCi} / \mathrm{L})$, which is below the drinking-water standard of $740 \mathrm{~Bq} / \mathrm{L}(20,000 \mathrm{pCi} / \mathrm{L})$. Concentrations of tritium have been declining in almost all wells monitoring the Building 75 tritium plume since closure of the NTLF in December 2001, with a concurrent reduction in the lateral extent of the plume. The maximum concentration of tritium detected in the Building $71 \mathrm{~B}$ area in 2007 was 13.8 $\mathrm{Bq} / \mathrm{L}(373 \mathrm{pCi} / \mathrm{L})$.

\subsubsection{Petroleum Hydrocarbon Plumes}

Petroleum hydrocarbon-contaminated groundwater is present in two areas where USTs formerly were located: north of Building 6 and near Building 74 No aromatic VOCs, including BTEX components (i.e., benzene, toluene, ethyl benzene, xylenes), have been detected at either of the UST sites since 2003. A dual-phase (groundwater and soil vapor) extraction and treatment system was installed north of Building 6 in 1998 as an interim corrective measure and continues to operate.

\subsubsection{Treatment Systems}

As described above, Berkeley Lab is using collection trenches and subdrains to control the migration of groundwater plumes. Eleven GAC systems were operated in 2007 to treat the extracted groundwater. The treated water is used mainly for on-site soil-flushing activities. Excess water is released to the sanitary sewer in accordance with Berkeley Lab's treated groundwater discharge permit from EBMUD. ${ }^{28}$

The total volume of contaminated groundwater treated by these systems during the year was about 4,800 $\mathrm{m}^{3}$ (12.1 million gal).

\subsection{SOIL AND SEDIMENT}

This section summarizes the monitoring results for soil and sediment samples.

\subsubsection{Soil Sampling Results}

Soil samples obtained from the top 2 to $5 \mathrm{~cm}$ (1 to 2 in) of surface soils were collected from three locations on the Laboratory site and one off-site environmental monitoring station (see Figure 4-7). Samples were analyzed for 


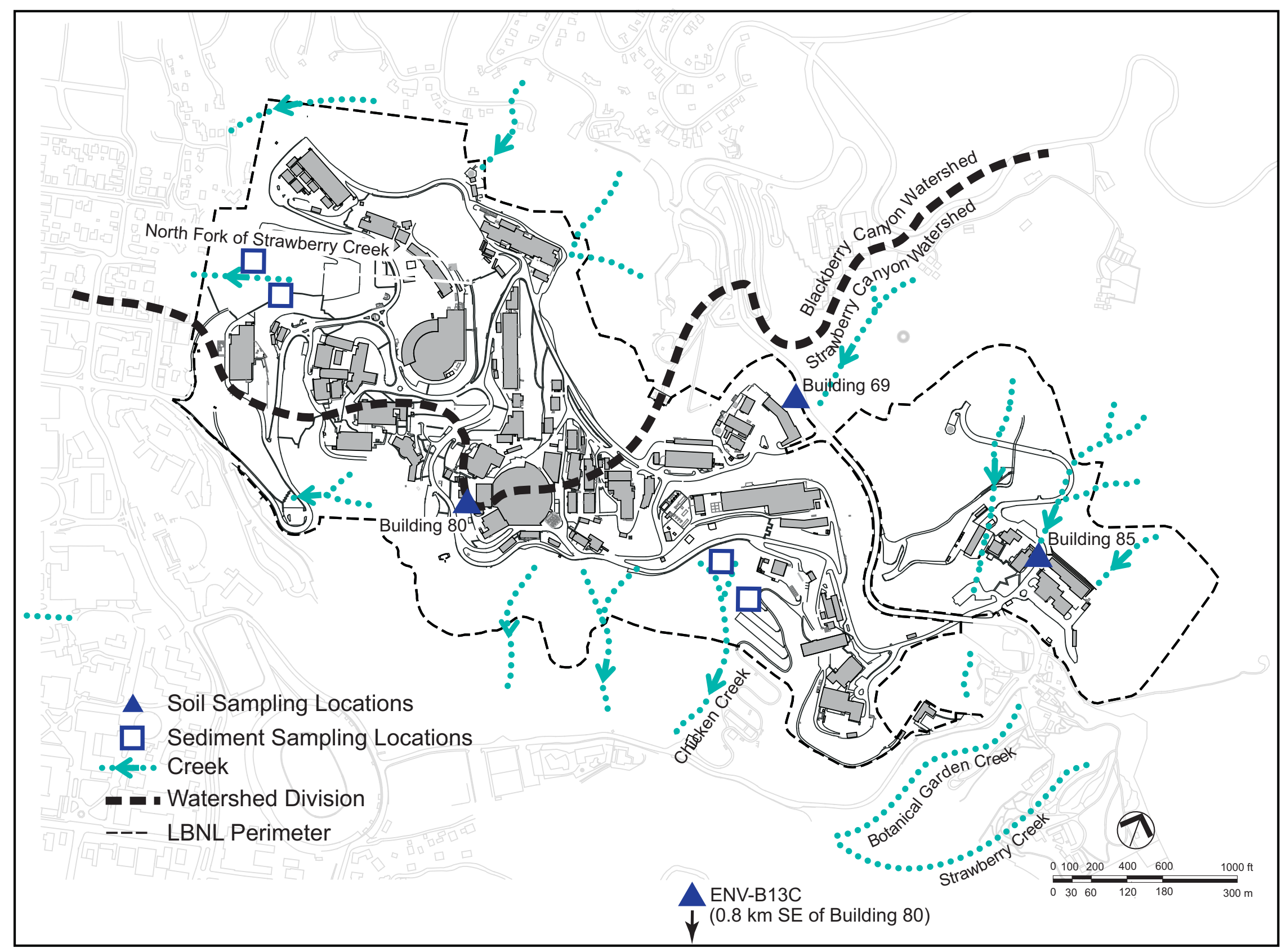


gross alpha and gross beta radiation, gamma emitters, tritium, moisture content, $\mathrm{pH}$, and fifteen individual metals.

For radioisotope analysis, the alpha, beta, and gamma emitter results were similar to background levels of naturally occurring radioisotopes commonly found in soils. Tritium measurements at each of the sampling locations were below detection limits.

For non-radioisotope analysis, measurements of $\mathrm{pH}$ and moisture content at each of the sampling locations were within the typical range for soils. For the ten metals with established Berkeley Lab soil background levels, ${ }^{29}$ concentrations were within background levels, except for lead in one sample. For the other five metals, concentrations were within levels commonly found in California soils. Mercury soil values, which were slightly elevated in last year's samples, were all below the detection limit of 0.2 milligrams per kilogram $(\mathrm{mg} / \mathrm{kg})$.

\subsubsection{Sediment Sampling Results}

Sediment samples were collected in the creek beds of the North Fork of Strawberry Creek and Chicken Creek (see Figure 4-7). Due to limited sediment availability in the tributary and main sampling locations, several grab samples from the general sampling area of each location were composited and analyzed. These sites were renamed 1) The North Fork of Strawberry Creek and 2) Chicken Creek (the tributary and main titles were removed). Future sampling at these locations will be done in a similar manner.

Samples were analyzed for gross alpha, gross beta, and gamma emitters, tritium, fifteen individual metals, $\mathrm{pH}$, moisture content, and petroleum hydrocarbons (diesel and oil/grease).

For radioisotope analysis, the levels of alpha, beta, and gamma emitters were within background levels of naturally occurring radioisotopes commonly found in sediments. Tritium measurements at each of the sampling locations were below detection limits.

For non-radioisotope analysis, concentrations of the ten metals with established Berkeley Lab soil background levels ${ }^{30}$ were within those levels. Concentrations of the other five metals were within levels commonly found in California soils. Measurements of $\mathrm{pH}$, moisture content, and petroleum hydrocarbons (diesel and oil/grease) at all of the locations were within the historical values typically found at the Berkeley Lab site over the past five years.

\subsection{VEGETATION AND FOODSTUFFS}

Sampling and analysis of vegetation and foodstuffs can provide information regarding the presence, transport, and distribution of radioactive emissions in the environment. This information can be used to detect and evaluate changes in environmental radioactivity resulting from Berkeley Lab activities and to calculate potential human doses that would occur from consuming vegetation and foodstuffs.

Due to historical air emissions from the former NTLF Hillside Stack, vegetation near that site contains measurable concentrations of tritium. Tritium in vegetation occurs in two chemical forms - tissue-free water tritium and organically bound tritium — and Berkeley Lab analyzes vegetation for both forms.

Since the closure of the NTLF in December of 2001, tritium emissions from Berkeley Lab have decreased sharply. Tritium concentrations in vegetation will decrease more slowly over time, as indicated by the results from the last sampling in 2005. To document changes in the concentrations of tritium in the local vegetation, Berkeley Lab samples it at least every five years; in 2007, no routine vegetation samples were collected for this purpose. 


\subsection{PENETRATING RADIATION MONITORING}

Radiation-producing machines (e.g., accelerators, x-ray machines, irradiators) and various radionuclides are used at Berkeley Lab for high-energy particle studies and biomedical research. Penetrating radiation is associated primarily with accelerator and irradiator operations at the Laboratory.

When operating, accelerators produce both gamma radiation and neutrons. To detect gamma radiation and neutrons from accelerator operations, Berkeley Lab places radiation-detection equipment at environmental monitoring stations near the site's research accelerators, which include the Advanced Light Source Facility (Building 6), Biomedical Isotope Facility (Building 56), and 88-Inch Cyclotron (Building 88).

The Laboratory uses two methods to determine the environmental radiological impact from accelerator operations:

- Real-time monitors that continuously detect and record gamma radiation and neutron doses

- Passive detectors called "optically stimulated luminescence dosimeters," which by laboratory analysis provide an average dose over time from gamma radiation

The locations of real-time monitors and dosimeters are shown in Figure 4-8. Results of both measurement methods are given in terms of dose and are provided in Section 5.2 .

Irradiators at Berkeley Lab produce only gamma radiation. Used for radiobiological and radiophysics research, a gamma irradiator that uses sealed cobalt-60 sources is housed at Berkeley Lab in Building 74; the irradiator is in a massive interlocked structure that is covered with reinforced concrete. Routine surveys confirmed that the maximum gamma radiation doses at $1 \mathrm{~m}$ (3.3 ft) from the outside walls or ceiling of the building were indistinguishable from background levels (0.002 $\mathrm{mSv}$ per hour $(\mathrm{mSv} / \mathrm{hr})[0.2 \mathrm{mrem} / \mathrm{hr}])$.
Berkeley Lab also uses other, smaller, well-shielded gamma irradiators that pose considerably less potential for environmental impact than does the Building 74 irradiator. This class of smaller irradiators does not measurably increase the dose to the public. 


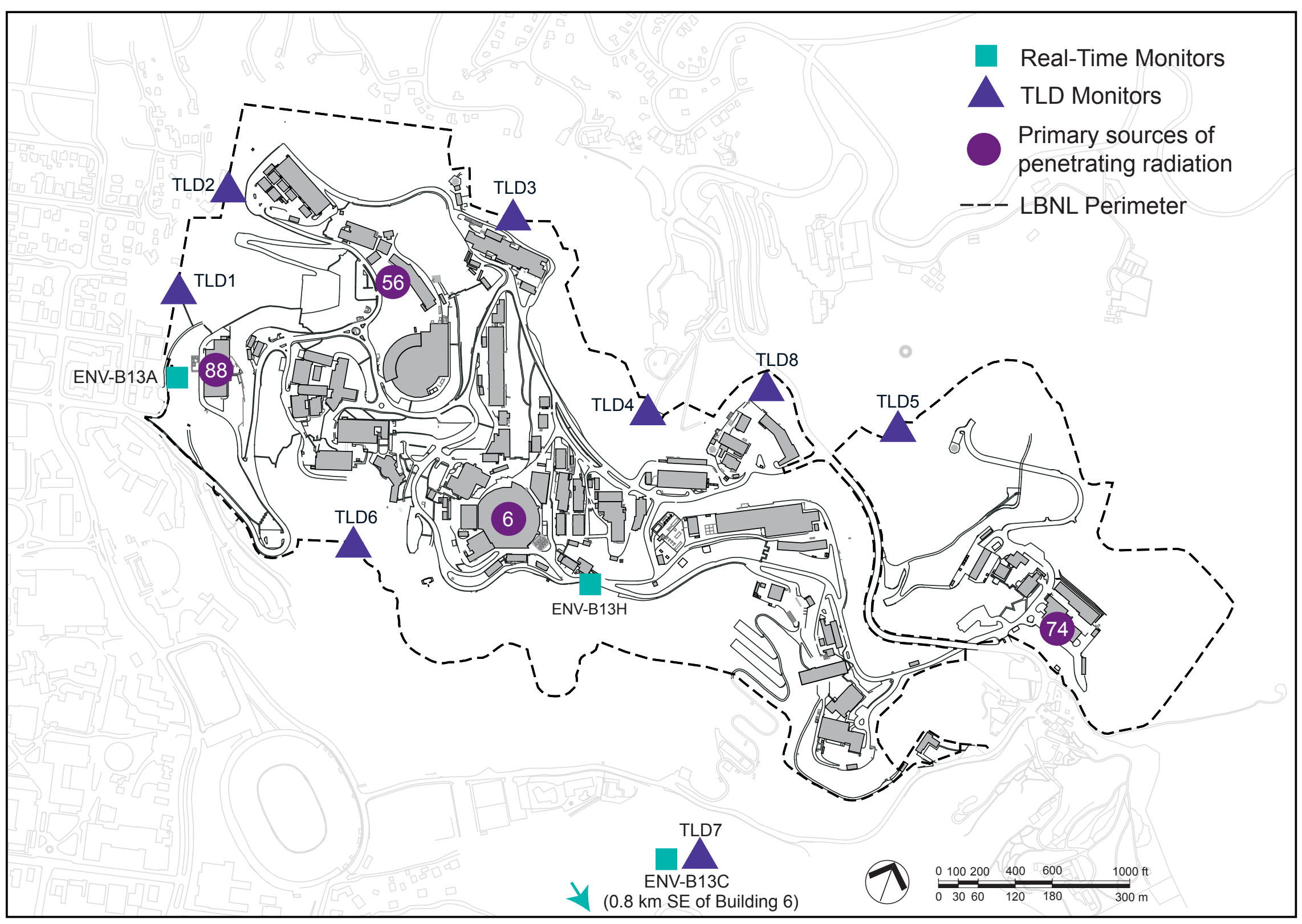

Figure 4-8 Environmental Penetrating Radiation Monitoring Stations 


\section{Radiological Dose Assessment}

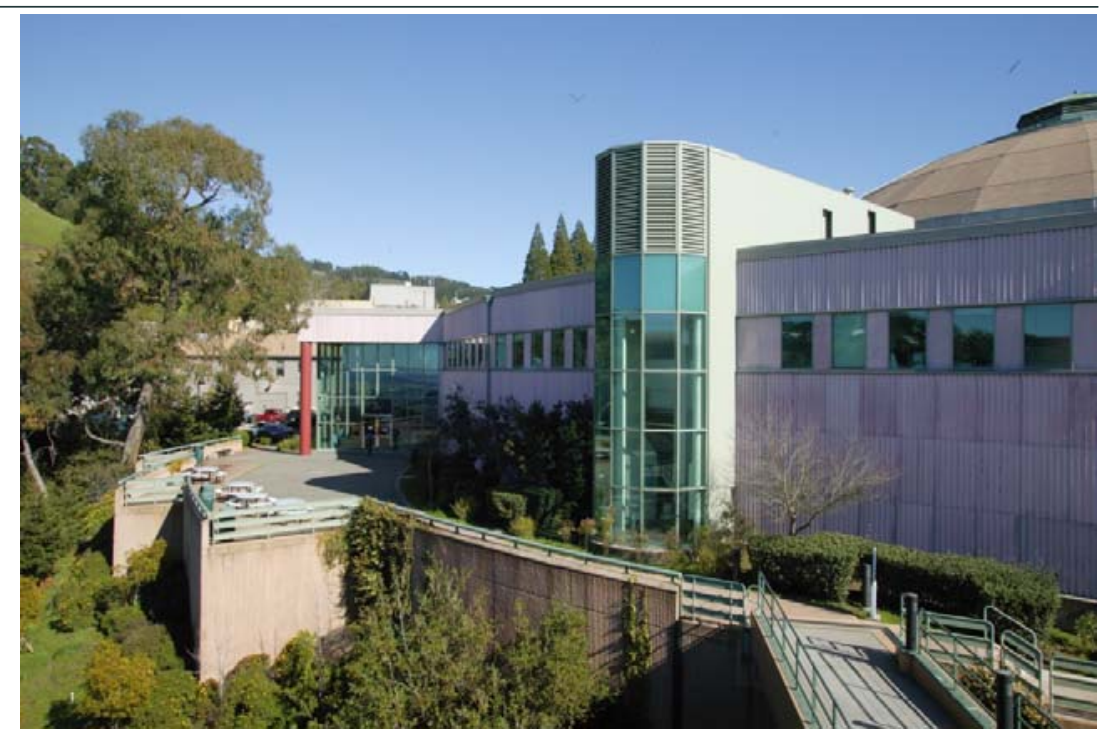

West side of the Advanced Light Source Facility

5.1 BACKGROUND

5.2 DOSERROMPENEIRATING RADIATION

5.3 DOSERROMDISPERSIBLEARBORNERADIONUCLDES

$5-2$ 


\subsection{BACKGROUND}

Earlier chapters refer to monitoring and sampling results in terms of concentrations of a substance. An exposure to concentrations of a substance over a period of time is referred to as "dose." Because doses are calculated rather than measured, they represent potential or estimated, instead of actual, doses. This chapter presents the estimated dose results from Lawrence Berkeley National Laboratory's penetrating radiation and airborne radionuclide monitoring programs. These doses include all known radionuclides released in significant quantities from Berkeley Lab. The doses projected from each monitoring program are presented separately before they are cumulatively evaluated to summarize the overall impact of the Laboratory's radiological activities on members of the public. Additionally, the radiological impact of Berkeley Lab's operations on local animals and plants is discussed.

To minimize radiological impacts to the environment and the public, Berkeley Lab manages its programs so that radioactive emissions and external exposures are as low as reasonably achievable (ALARA). The Laboratory's Environmental ALARA Program ensures that a screening (qualitative) review is performed on activities that could result in a dose to the public or the environment. Potential doses from activities that may generate airborne radionuclides are estimated through the $\mathrm{NESHAP}^{1}$ process (discussed in Section 4.2). If the potential for a public dose is greater than $0.01 \mathrm{mSv}$ (1 mrem) to an individual or 0.1 person-sievert (person-Sv) (10 person-rem) to a population, an in-depth quantitative review is required. No quantitative reviews were required or performed in 2007.

\subsection{DOSE FROM PENETRATING RADIATION}

As discussed in Section 4.7, penetrating radiation from Berkeley Lab operations is measured by real-time monitors and dosimeters. Results of penetrating radiation measurements by both methods indicate that the maximum dose to a member of the public (person residing near the 88-inch Cyclotron) and the collective dose to the surrounding population from penetrating radiation were indistinguishable from natural background levels.

\subsection{DOSE FROM DISPERSIBLE AIRBORNE RADIONUCLIDES}

Dose due to dispersible contaminants represents the time-weighted exposure to a concentration of a substance, whether the concentration is inhaled in air, ingested in drink or food, or absorbed through skin contact with soil or other environmental media. Dispersible radionuclides originate as emissions from building exhaust points generally located on rooftops, as discussed in Section 4.2.1. Once emitted, these radionuclides may affect any of several environmental media: air, water, soil, plants, and animals. Each of these media represents a possible pathway of exposure affecting human dose.

Dose to an individual and the population is determined using computer dispersion models. The NESHAP regulation ${ }^{2}$ requires that any facility that releases airborne radionuclides assess the impact of such releases using a computer program approved by the U.S. EPA. Berkeley Lab satisfies this requirement with the use of the U.S. EPA-approved program CAP88-PC. ${ }^{3}$ Details of dose calculations from dispersible airborne radionuclides are included in the Laboratory's annual NESHAP report, available at the Berkeley Public Library. The report may be found at: www.lbl.gov/ehs/esg under "Available Documents."

Based on these calculations, the maximally exposed individual (MEI) to airborne emissions was determined to be a hypothetical person residing at the Lawrence Hall of Science (LHS). The maximum possible dose to the MEI from airborne radionuclides for 2007 was about $1.2 \times 10^{-4} \mathrm{mSv}(0.012 \mathrm{mrem})$. This value is about $0.1 \%$ of the DOE and U.S. EPA annual limit $(0.10$ $\mathrm{mSv} / \mathrm{yr}[10 \mathrm{mrem} / \mathrm{yr}]){ }^{4,5}$ 
The dose from airborne radionuclides to the surrounding population is estimated for a region that extends from the site for $80 \mathrm{~km}$ (50 mi). Within this area, the population is about $6,615,000 .^{6}$ The estimated population dose from all airborne radionuclides for the year was $3.1 \times 10^{-3}$ person-Sv $(0.31$ person-rem).

\subsection{TOTAL DOSE TO THE PUBLIC}

The total radiological impact to the public from penetrating radiation and airborne radionuclides is well below applicable standards and local background radiation levels. Because the greatest possible dose from penetrating radiation was indistinguishable from doses due to background radiation, the 2007 total dose to the MEI from Berkeley Lab activities is due solely to exposure to airborne radionuclides. As presented in Figure 5-1, the maximum effective dose equivalent from Berkeley Lab operations to an individual residing at LHS in 2007 was about $1.2 \times 10^{-4} \mathrm{mSv} / \mathrm{yr}(0.012$ $\mathrm{mrem} / \mathrm{yr})$. This dose was primarily from fluorine-18 from the cyclotron at the Biomedical Isotope Facility (Building 56) and from iodine-123 used in biomedical research in Building 55. This value is approximately $0.003 \%$ of the average United States background radiation ${ }^{7}$ (3.6 $\mathrm{mSv} / \mathrm{yr}$ [360 $\mathrm{mrem} / \mathrm{yr}])$ and about $0.01 \%$ of the DOE annual limit from all sources $(1.0$ $\mathrm{mSv} / \mathrm{yr}[100 \mathrm{mrem} / \mathrm{yr}]) .^{8}$

As noted previously, the estimated dose to the population within $80 \mathrm{~km}(50$ mi) of Berkeley Lab from airborne radionuclides emitted by laboratory operations was $3.1 \times 10^{-3}$ person-Sv (0.31 person-rem) for the same period. From natural background airborne radionuclides alone, this same population receives an estimated dose of 12,000 person-Sv (1,200,000 person-rem). ${ }^{9}$ The dose to the population from Berkeley Lab is less than $0.00003 \%$ of the background level, or about 3.9 million times lower than background level.

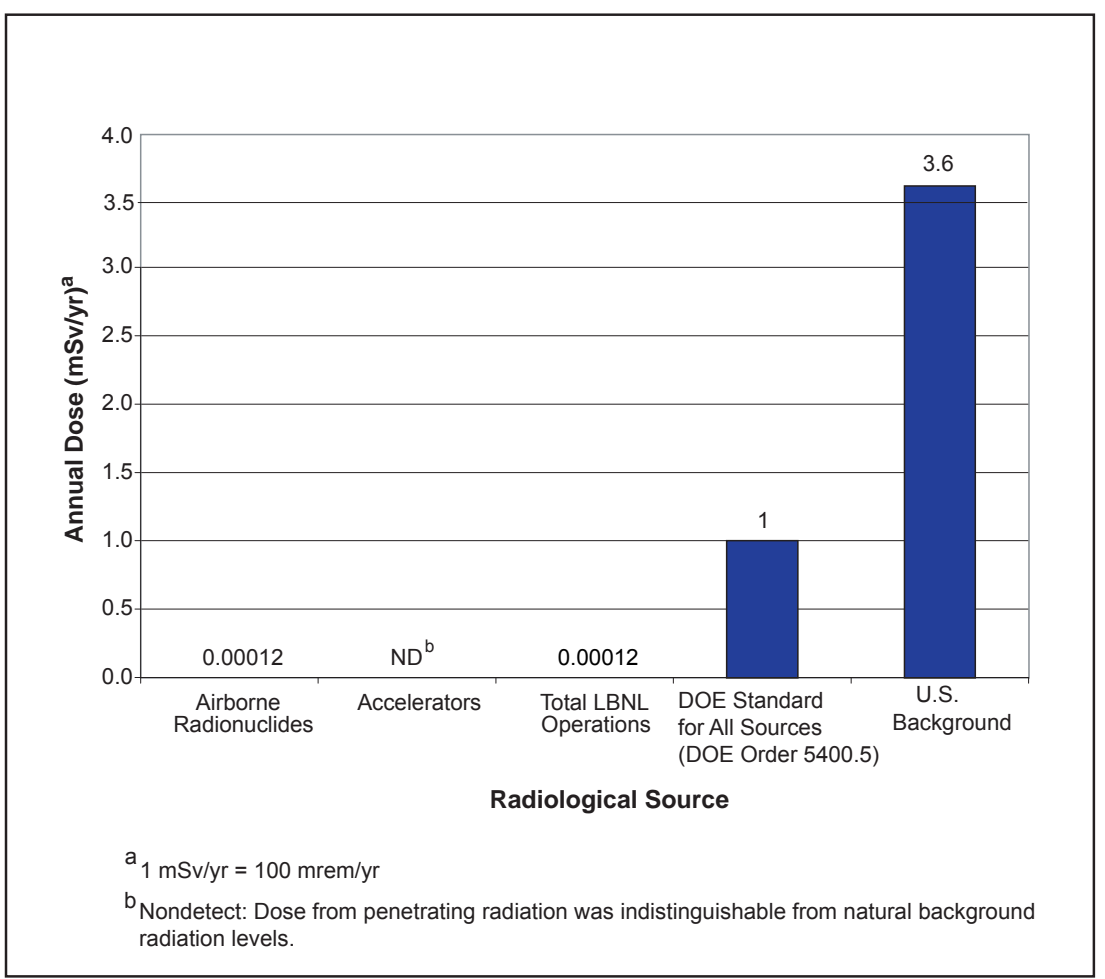

Figure 5-1 Comparison of Radiological Dose Impacts for 2007

\subsection{DOSE TO ANIMALS AND PLANTS}

Liquid and airborne emissions may have pathways to animals and plants in addition to their pathways to humans. DOE requires that aquatic organisms be protected by limiting their radiation doses to $1 \mathrm{rad} /$ day $(0.01$ gray per day $[\mathrm{Gy} / \mathrm{day}]]^{10}$. In addition, international recommendations suggest that doses to terrestrial animals should be limited to less than $0.1 \mathrm{rad} /$ day $(0.001 \mathrm{~Gy} /$ day $)$, and doses to terrestrial plants should be limited to $1 \mathrm{rad} /$ day $(0.01 \mathrm{~Gy} /$ day $) .{ }^{11}$

Several sources of exposure were considered, including animal ingestion of vegetation, water, and soil; animal inhalation of soil; plant uptake of water; and external exposure of animals and plants to radionuclides in water, soil, and 
sediment. Creek water, soil, and sediment samples were collected and analyzed for several radionuclides, including tritium, alpha-emitting radionuclides, and beta-emitting radionuclides. Alpha- and beta-emitting radionuclides in soil and sediment were further characterized by gamma spectroscopy.

These radionuclides were measured at levels similar to natural background levels, or well below standards. Sample results are provided in Volume II. Alpha- and beta-emitting radionuclides and tritium were evaluated using the DOE-endorsed computer model RESRAD-BIOTA. ${ }^{12}$ Both terrestrial and aquatic systems passed the "general screening process" (described in a DOEapproved technical standard), ${ }^{13}$ which confirms that Berkeley Lab is in compliance with DOE requirements to limit radiation doses to aquatic organisms to $1 \mathrm{rad} /$ day $(0.01 \mathrm{~Gy} /$ day). It also shows that the Laboratory is well within international recommendations for limiting dose to other plants and animals. 


\section{Quality Assurance}

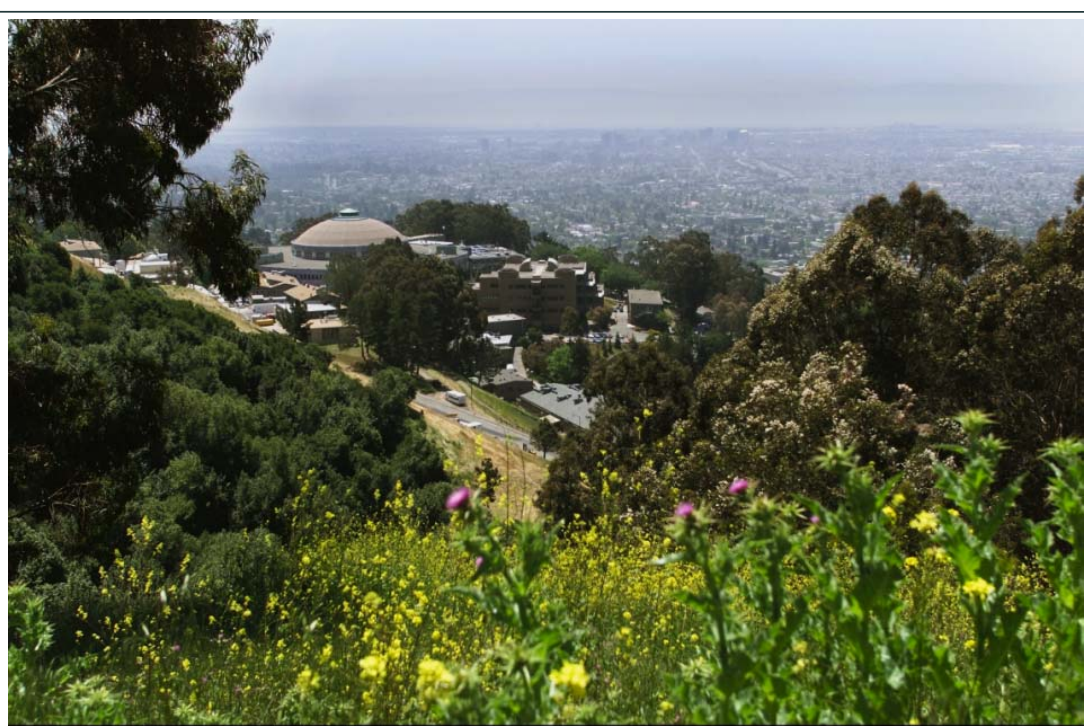

View of Berkeley Lab from the hills above

6.1 OVERMEW

6.2 PROFLEOFEMMRONMENTAL MONITORING SAMPLES ANDRESULTS

6.3

SPUT AND DUPUCATERESULTS RROM

EMRONMENTAL MONITORING

6.4

QUAUTY CONTROL RESULTS RROMANALYTICAL

LABORATORIES

$6-2$ 


\subsection{OVERVIEW}

Lawrence Berkeley National Laboratory's quality assurance (QA) policy is documented in the Operating and Quality Management Plan (OQMP). ${ }^{1}$ The OQMP consists of a set of operating principles used to support internal organizations in achieving consistent, safe, and high-quality performance in their work activities. OQMP principles are applied to individual programs through a graded approach, with consideration given to factors such as environmental, health, and safety consequences.

In addition to the OQMP, the monitoring and sampling activities and results presented in this report were conducted in accordance with Berkeley Lab's Environmental Monitoring Plan ${ }^{2}$ and applicable $\mathrm{DOE}^{3}$ and U.S. EPA ${ }^{4}$ guidance. When special QA and QC requirements are necessary for environmental monitoring (such as the NESHAP stack monitoring program), a Quality Assurance Project Plan is developed and implemented.

On-site and external analytical laboratories analyze samples for the environmental monitoring program. Both types of laboratories must meet demanding QA and QC specifications and certifications ${ }^{5}$ that were established to define, monitor, and document laboratory performance. The QA and QC data provided by these laboratories are incorporated into Berkeley Lab's processes performed to assess data quality. For 2007, seven external analytical laboratories were available for use under contract(s) jointly administered by Berkeley Lab and Lawrence Livermore National Laboratory.

Each set of data (batch) received from the analytical laboratory is systematically evaluated and compared to established data-quality objectives before the results can be authenticated and accepted into the environmental monitoring database. Categories of data-quality objectives include accuracy, precision, representativeness, comparability, and completeness. When possible, quantitative criteria are used to define and assess data quality.
The DOE Consolidated Audit Program (DOECAP) annually audits all external analytical laboratories supporting DOE facilities, including those working with Berkeley Lab. In general, DOECAP audits are two to three days in length, with five or more auditors participating in the audit. A member of DOE or a DOE contractor representative, trained as a Nuclear Quality Assurance lead auditor, heads the DOECAP audit team. Other team members come from across the DOE complex and add a wealth of experience. Typically, Berkeley Lab sends one representative to participate in DOECAP audits of Berkeley Lab's external analytical laboratory locations. The team audits each of the following six areas that pertain to the services provided by the particular external analytical laboratory:

- QA management systems and general laboratory practices

- Organic analyses

- Inorganic and wet chemistry analyses

- Radiochemical analyses

- Laboratory information management systems and electronic deliverables

- Hazardous and radioactive material management

The laboratory audits also include a review of the external analytical laboratory's performance in proficiency testing required by the California Environmental Laboratory Accreditation Program. Only one of the seven external laboratories had a major deficiency which was found during an audit. Work with this laboratory was stopped. Any minor deficiencies identified in the audits are followed by corrective action plans and are tracked to closure.

To verify that environmental monitoring activities are adequate and effective, internal assessments are performed. In 2007, an ESG subject-matter expert performed assessments, and the Berkeley Lab Office of Contract Assurance performed an independent internal audit, of the NESHAP Monitoring 
Program. These assessments found the NESHAP program to be in compliance with U.S. EPA and Berkeley Lab requirements.

In addition, external oversight of Berkeley Lab programs is performed through the DOE Operational Awareness Program. ${ }^{6}$ Operational awareness activities are ongoing and include field orientation, meetings, audits, workshops, document and information system reviews, and day-to-day communications. DOE criteria for performance evaluation include (1) federal, state, and local regulations with general applicability to DOE facilities and (2) applicable DOE requirements. This program enables DOE to directly oversee Berkeley Lab programs and assess performance.

\subsection{PROFILE OF ENVIRONMENTAL MONITORING SAMPLES AND RESULTS}

Berkeley Lab's environmental monitoring program collected over 2,600 individual samples (air, sediment, soil, and water) throughout the year; the samples generated more than 108,650 analytical results. The Environmental Restoration Program sampling efforts, which are being included in these totals for the first time, accounted for just over $75 \%$ of the individual samples and over $98 \%$ of the analytical results.

Samples collected by these programs were obtained from nearly 700 different locations on or surrounding the Berkeley Lab site. Individual data results for all environmental monitoring programs, except the Environmental Restoration Program, are presented in Volume II. Detailed discussion of sampling conducted by the Environmental Restoration program can be found at http://www.lbl.gov/ehs/erp/html/documents.shtml and at the Berkeley Public Library.

\subsection{SPLIT AND DUPLICATE RESULTS FROM ENVIRONMENTAL MONITORING}

An essential activity undertaken to measure the quality of environmental monitoring results is the regular collection and analysis of split and duplicate samples collected in the field. In 2007, a total of 58 split and 101 duplicate samples from all programs were collected for either radiological or nonradiological (or both) analyses, leading to 356 and 245 analytical results, respectively. Additionally, there were 263 blank samples submitted for QA purposes. Blank samples are useful because they can identify contamination that was obtained outside of the sampling period.

Berkeley Lab uses the metrics of relative percent difference and relative error ratio to determine whether paired results (split-sample; duplicate-sample) are within control limits. Relative percent difference is defined as the absolute value of the difference between two results divided by the mean of the two results. Relative error ratio is defined as the absolute value of the difference between two results divided by the sum of the analytical error of the two results. Relative percent difference is determined in all cases; relative error ratio is applicable only to radiological analyses where analytical error is determined.

When the primary sample and the split or duplicate sample results are below analytical detection limits, results from these tests are not meaningful. When QA pair results are outside of control limits, an investigation is performed to determine the cause of the discrepancy.

\subsection{QUALITY CONTROL RESULTS FROM ANALYTICAL LABORATORIES}

Analytical laboratories routinely perform QC tests to assess the quality and validity of their sample results. These tests are run with each batch of environmental samples submitted by Berkeley Lab. The same relative percent difference and relative error ratio metrics are used to evaluate these 
control sample results, with the relative error ratio test applicable only to radiological analyses.

Seven analytical laboratories performed 2,285 radiological and nonradiological QC analyses to coincide with batches of samples submitted to Berkeley Lab. These QC analyses include various types of blank, replicate (also referred to as duplicate), matrix spike, and laboratory control samples. Table 6-1 shows the breadth and diversity of this program.

In addition to the relative percent difference and relative error ratio tests, lower and upper control limits are established for each analyte and for each type of QC test. As with split and duplicate QA, when QC results are outside of established criteria, an investigation is performed to determine the cause of the discrepancy.

Table 6-1 Summary of Quality Control Testing Performed by Analytical Laboratories in 2007

\begin{tabular}{|lccccc|}
\hline \multicolumn{1}{|c}{ Program } & $\begin{array}{c}\text { Sample } \\
\text { Batches }\end{array}$ & QC Analyses & $\begin{array}{c}\text { Laboratories } \\
\text { Involved }\end{array}$ & Radiological $^{\mathrm{a}}$ & $\begin{array}{c}\text { Non- } \\
\text { Radiological }^{\mathrm{b}}\end{array}$ \\
\hline Ambient air & 26 & 61 & 2 & $\mathrm{X}$ & \\
Groundwater & 170 & 1,001 & 3 & $\mathrm{X}$ & $\mathrm{X}$ \\
Rainwater & 18 & 69 & 3 & $\mathrm{X}$ & \\
Sediment & 4 & 34 & 4 & $\mathrm{X}$ & $\mathrm{X}$ \\
Soil & 4 & 22 & 4 & $\mathrm{X}$ & $\mathrm{X}$ \\
Soil water & 3 & 8 & 1 & $\mathrm{X}$ & \\
Stack air & 59 & 192 & 4 & $\mathrm{X}$ & \\
Stormwater and creeks & 27 & 172 & 6 & $\mathrm{X}$ & $\mathrm{X}$ \\
Wastewater & 91 & 726 & 6 & $\mathrm{X}$ & $\mathrm{X}$ \\
\hline
\end{tabular}

${ }^{a} \mathrm{An}$ " $\mathrm{X}$ " in this column denotes that the program tests for radiological substances.

${ }^{\mathrm{b}} \mathrm{An}$ " $\mathrm{X}$ " in this column denotes that the program tests for nonradiological substances. 


\section{Acronyms and}

\section{Abbreviations}

$\begin{array}{ll}\text { AEDE } & \text { annual effective dose equivalent } \\ \text { AHD } & \text { Activity Hazard Document } \\ \text { ALARA } & \text { as low as reasonably achievable } \\ \text { AST } & \text { aboveground storage tank } \\ \text { BAAQMD } & \text { Bay Area Air Quality Management District } \\ \text { Basin Plan } & \text { Water Quality Control Plan for the San Francisco Bay } \\ & \text { Basin } \\ \text { Berkeley Lab } & \text { Ernest Orlando Lawrence Berkeley National } \\ \text { Bq } & \text { Laboratory } \\ \text { C } & \text { becquerel } \\ \text { CAP } & \text { Celsius } \\ \text { CARB } & \text { Corrective Action Program } \\ \text { CCCSD } & \text { California Air Resources Board } \\ \text { CEQA } & \text { Central Contra Costa Sanitary District } \\ \text { CERCLA } & \text { California Environmental Quality Act } \\ \text { CFR } & \text { Comprehensive Environmental Response, } \\ \text { Ci } & \text { Code of Federal Regulations } \\ \text { cm } & \text { curie } \\ \text { CMI } & \text { centimeter } \\ \text { CMS } & \text { Corrective Measures Implementation } \\ \text { COD } & \text { Corrective Measure Study } \\ \text { CWA } & \text { chemical oxygen demand } \\ \text { CY } & \text { Clean Water Act } \\ \text { DCA } & \text { calendar year } \\ & \text { dichloroethane } \\ & \end{array}$




\begin{tabular}{|c|c|c|c|}
\hline DCE & dichloroethylene & in & inch \\
\hline DHS & Department of Health Services (now DPH) & ISM & Integrated Safety Management \\
\hline DOE & United States Department of Energy & ISO & International Organization for Standardization \\
\hline DOECAP & DOE Consolidated Audit Program & JGI & Joint Genome Institute \\
\hline DPH & Department of Public Health (formerly DHS) & $\mathrm{kg}$ & kilogram \\
\hline DPM & diesel particulate matter & $\mathrm{km}$ & kilometer \\
\hline DTSC & Department of Toxic Substances Control & $\mathrm{L}$ & liter \\
\hline EBMUD & East Bay Municipal Utility District & $\mathrm{lb}$ & pound \\
\hline $\mathrm{EH} \& \mathrm{~S}$ & $\begin{array}{l}\text { Environment, Health, and Safety Division at Berkeley } \\
\text { Lab }\end{array}$ & $\begin{array}{l}\text { LBNL } \\
\text { LHS }\end{array}$ & $\begin{array}{l}\text { Lawrence Berkeley National Laboratory } \\
\text { Lawrence Hall of Science }\end{array}$ \\
\hline EMP & Environmental Management Program & $\mathrm{m}$ & meter \\
\hline EMS & Environmental Management System & $\mathrm{m}^{3}$ & cubic meter \\
\hline EPCRA & $\begin{array}{l}\text { Emergency Planning and Community Right-to-Know } \\
\text { Act }\end{array}$ & MEI & maximally exposed individual \\
\hline ESG & Environmental Services Group & $\mu g$ & microgram \\
\hline $\mathrm{F}$ & Fahrenheit & $\mathrm{mg}$ & milligram \\
\hline $\mathrm{ft}$ & foot & mi & mile \\
\hline FTU & fixed treatment unit & MNA & monitored natural attenuation \\
\hline FY & fiscal year & mrem & millirem \\
\hline GAC & granular activated carbon & $\mathrm{mSv}$ & millisievert \\
\hline gal & gallon & NEPA & National Environmental Policy Act \\
\hline General Permit & Industrial Activities Storm Water General Permit & NESHAP & $\begin{array}{l}\text { National Emission Standards for Hazardous Air } \\
\text { Pollutants }\end{array}$ \\
\hline gsf & gross square feet & $\mathrm{NOV}$ & Notice of Violation \\
\hline gsm & gross square meters & NTLF & National Tritium Labeling Facility \\
\hline Gy & gray (measure of radiation in $\mathrm{SI}$ ) & OQMP & Operating and Quality Management Plan \\
\hline HMBP & Hazardous Materials Business Plan & PBT & persistence, bioaccumulation, and toxicity \\
\hline $\mathrm{hr}$ & hour & PCB & polychlorinated biphenyl \\
\hline HRC & Hydrogen Release Compound & PCE & perchloroethylene (tetrachloroethylene) \\
\hline HWHF & Hazardous Waste Handling Facility & $\mathrm{pCi}$ & picocurie (one trillionth of a curie) \\
\hline
\end{tabular}




$\begin{array}{ll}\text { QA } & \text { quality assurance } \\ \text { QC } & \text { quality control } \\ \text { RCP } & \text { Recycled Content Products } \\ \text { RCRA } & \text { Resource Conservation and Recovery Act } \\ \text { rem } & \text { roentgen equivalent man } \\ \text { RMPP } & \text { Risk Management and Prevention Plan } \\ \text { RWQCB } & \text { Regional Water Quality Control Board } \\ \text { S } & \text { second } \\ \text { SARA } & \text { Superfund Amendments and Reauthorization Act } \\ \text { SI } & \text { Système Internationale or International System of Units } \\ & \text { the metric system) } \\ \text { SPCC } & \text { Spill Prevention, Control, and Countermeasures } \\ \text { Sv } & \text { sievert } \\ \text { SWDA } & \text { Solid Waste Disposal Act } \\ \text { SWMP } & \text { Storm Water Monitoring Program } \\ \text { SWPPP } & \text { Storm Water Pollution Prevention Plan } \\ \text { SWRCB } & \text { State Water Resources Control Board } \\ \text { TCA } & \text { trichloroethane } \\ \text { TCE } & \text { trichloroethylene } \\ \text { TOC } & \text { total organic carbon } \\ \text { TPH } & \text { total petroleum hydrocarbons } \\ \text { TRI } & \text { Toxic Release Inventory } \\ \text { TSCA } & \text { Toxic Substances Control Act } \\ \text { TSS } & \text { total suspended solids } \\ \text { UC } & \text { University of California } \\ \text { UCOP } & \text { University of California Office of the President } \\ \text { UHVCF } & \text { Ultra-High Vacuum Cleaning Facility } \\ \text { USC } & \text { United States Code } \\ \text { U.S. EPA } & \text { United States Environmental Protection Agency } \\ & \end{array}$

$\begin{array}{ll}\text { USFWS } & \text { United States Fish and Wildlife Service } \\ \text { UST } & \text { underground storage tank } \\ \text { UV } & \text { ultraviolet } \\ \text { VOC } & \text { volatile organic compound } \\ \text { WAA } & \text { Waste Accumulation Area } \\ \text { Web } & \text { World Wide Web } \\ \mathrm{yd}^{3} & \text { cubic yard } \\ \mathrm{yr} & \text { year }\end{array}$




\section{Glossary}

\section{accuracy}

The degree of agreement between a measurement and the true value of the quantity measured.

\section{air particulates}

Airborne particles that include dust, dirt, and other pollutants occurring as particles, as well as any pollutants associated with or carried on the dust or dirt.

\section{alpha particle}

A charged particle comprising two protons and two neutrons, which is emitted during decay of certain radioactive atoms. Alpha particles are stopped by several centimeters of air or a sheet of paper.

\section{ambient air}

The surrounding atmosphere, usually the outside air, as it exists around people, plants, and structures. It does not include the air next to emission sources.

\section{analyte}

The subject of a sample analysis.

\section{background radiation}

Ionizing radiation from sources other than LBNL. Background may include cosmic radiation; external radiation from naturally occurring radioactivity in the earth (terrestrial radiation), air, and water; internal radiation from naturally occurring radioactive elements in the human body; and radiation from medical diagnostic procedures.

\section{becquerel}

SI unit of radioactive decay equal to one disintegration per second. 


\section{beta particle}

A charged particle, identical to the electron, that is emitted during decay of certain radioactive atoms. Most beta particles are stopped by less than 0.6 centimeter of aluminum.

\section{contaminant}

Any hazardous or radioactive material present in an environmental medium such as air, water, or vegetation.

\section{cosmic radiation}

High-energy particulate and electromagnetic radiation that originates outside the earth's atmosphere. Cosmic radiation is part of natural background radiation.

\section{curie}

Unit of radioactive decay equal to $2.22 \times 10^{12}$ disintegrations per minute (conventional units).

\section{de minimis}

A level that is considered to be insignificant and does not need to be addressed or controlled.

\section{detection limit}

The lowest concentration of an analyte that can reliably be distinguished from a zero concentration.

\section{discharge}

The release of a liquid or pollutant to the environment or to a system (usually of pipes) for disposal.

\section{dose}

The quantity of radiation energy absorbed by a human, animal, or vegetation. Dose to humans is also called effective dose equivalent (measured in the International System [SI] of sieverts or conventional units of rem), which takes into account the type of radiation and the parts of the body exposed. Dose to animals and vegetation is also called absorbed dose (measured in the SI units of grays or conventional units of rad), which is the energy deposited per unit of mass.

\section{dose, population}

The sum of the radiation doses to individuals of a population. It is expressed in units of person-sievert (SI unit) or person-rem (conventional unit). For example, if 1,000 people each received a radiation dose of 1 sievert, their population dose would be 1,000 personsievert.

\section{dosimeter}

A portable detection device for measuring the total accumulated dose from ionizing radiation. See also optically stimulated luminescence dosimeter.

\section{downgradient}

In the direction of groundwater flow.

\section{duplicate sample}

A sample that is equivalent to a routine sample and is analyzed to evaluate sampling or analytical precision.

\section{effective dose equivalent}

Abbreviated EDE, it is the sum of the products of the dose equivalent received by specified tissues of the body and a tissue-specific weighting factor. This sum is a risk-equivalent value and can be used to estimate the health risk of the exposed individual. The tissue-specific weighting factor represents the fraction of the total health risk resulting from uniform whole-body irradiation that would be contributed by that particular tissue. The EDE includes the committed EDE from internal deposition of radionuclides and the EDE due to penetrating radiation from sources external to the body. EDE is expressed in units of sievert (SI unit) or rem (conventional unit). See dose.

\section{effluent}

A liquid waste discharged to the environment. 


\section{emission}

A release of air to the environment that contains gaseous or particulate matter having one or more contaminants.

\section{gamma radiation}

Short-wavelength electromagnetic radiation of nuclear origin that has no mass or charge. Because of its short wavelength (high energy), gamma radiation can cause ionization. Other electromagnetic radiation, such as microwaves, visible light, and radio waves, have longer wavelengths (lower energy) and cannot cause ionization.

\section{gray}

The gray is the International System (SI) unit for absorbed dose. One gray is an absorbed radiation dose of one joule per kilogram.

\section{groundwater}

Water below the land surface in a zone of saturation.

\section{half-life, radioactive}

The time required for the activity of a radioactive substance to decrease to half its value by inherent radioactive decay. After two half-lives, onefourth of the original activity remains $(1 / 2 \times 1 / 2)$; after three half-lives, one-eighth of the original activity remains $(1 / 2 \times 1 / 2 \times 1 / 2)$; and so on.

\section{hazardous waste}

Waste exhibiting any of the following characteristics: ignitability, corrosivity, reactivity, or EP-toxicity (yielding toxic constituents in a leaching test). Because of its concentration, quantity, or physical or chemical characteristics, it may (1) cause or significantly contribute to an increase in mortality rates or cases of serious irreversible illness or (2) pose a substantial present or potential threat to human health or the environment when improperly treated, stored, transported, disposed of, or handled.

\section{hydrauger}

A subhorizontal drain used to extract groundwater for slope stability purposes.

\section{low-level radioactive waste}

Waste containing radioactivity that is not classified as high-level waste, TRU waste, spent nuclear fuel, by-product material (as defined in Section 1 1e(2) of the Atomic Energy Act of 1954, as amended), or naturally occurring radioactive material.

\section{millirem}

A common unit for reporting human radiation dose. One millirem is one thousandth $\left(10^{-3}\right)$ of a rem. See rem.

\section{mixed waste}

Any radioactive waste that is also a U.S. EPA-regulated hazardous waste.

\section{nuclide}

A species of atom characterized by what constitutes the nucleus, which is specified by the number of protons, number of neutrons, and energy content; or, alternatively, by the atomic number, mass number, and atomic mass. To be regarded as a distinct nuclide, the atom must be able to exist for a measurable length of time.

\section{optically stimulated luminescence dosimeter}

A type of dosimeter. After being exposed to radiation, the material in the dosimeter luminesces on being stimulated by laser light. The amount of light that the material emits is proportional to the amount of radiation absorbed (dose). See also dosimeter.

\section{organic compound}

A chemical whose primary constituents are carbon and hydrogen.

\section{Part B permit}

The second, narrative section submitted by generators in the RCRA permitting process. It details the procedures followed at a facility to protect human health and the environment.

\section{person-rem}

See dose, population. 


\section{person-sievert}

See dose, population.

\section{$\mathrm{pH}$}

A measure of hydrogen ion concentration in an aqueous solution. Acidic solutions have a $\mathrm{pH}$ less than 7 ; basic solutions have a $\mathrm{pH}$ greater than 7; and neutral solutions have a $\mathrm{pH}$ of 7 .

\section{plume}

A volume of a substance that moves from its source to places farther away from the source. Plumes can be described by the volume of air or water they occupy and the direction they move. For example, a plume can be a column of smoke from a chimney or a substance moving with groundwater.

\section{pollutant}

Any hazardous or radioactive material present in an environmental medium such as air, water, or vegetation.

\section{positron}

A particle that is equal in mass to the electron but opposite in charge. A positively charged beta particle. ${ }^{3}$

\section{practical quantification limit}

The lowest concentration that can be reliably and consistently measured within specified limits of precision and accuracy.

\section{precision}

The degree of agreement between measurements of the same quantity.

\section{priority pollutants}

A set of organic and inorganic chemicals identified by U.S. EPA as indicators of environmental contamination.

\section{rad}

The conventional unit of absorbed dose from ionizing radiation, commonly used for dose to animals and vegetation.

\section{radiation protection standard}

Limits on radiation exposure regarded as necessary for protection of public health. These standards are based on acceptable levels of risk to individuals.

\section{radiation}

Electromagnetic energy in the form of waves or particles.

\section{radioactivity}

The property or characteristic of a nucleus of an atom to spontaneously disintegrate, accompanied by the emission of energy in the form of radiation.

\section{radiological}

Arising from radiation or radioactive materials.

\section{radionuclide}

An unstable nuclide. See nuclide and radioactivity.

\section{rem}

Acronym for "roentgen equivalent man." A unit of ionizing radiation, equal to the amount of radiation needed to produce the same biological effect to humans as $1 \mathrm{rad}$ of high-voltage $\mathrm{x}$ rays. It is the product of the absorbed dose, quality factor, distribution factor, and other necessary modifying factors. It describes the effectiveness of various types of radiation in producing biological effects.

\section{remediation}

The process of improving a contaminated area to a noncontaminated or safe condition.

\section{sievert}

The SI unit of effective dose equivalent in humans. It is the product of the absorbed dose, quality factor, distribution factor, and other necessary modifying factors. It describes the effectiveness of various types of radiation to produce biological effects. One sievert equals $100 \mathrm{rem}$. 


\section{source}

Any operation or equipment that produces, discharges, and/or emits pollutants (e.g., pipe, ditch, well, or stack), or the location where a pollutant was released to the environment.

\section{split sample}

A single well-mixed sample that is divided into parts for analysis and comparison of results.

\section{terrestrial}

Pertaining to or deriving from the earth.

\section{terrestrial radiation}

Radiation emitted by naturally occurring radionuclides, such as ${ }^{40} \mathrm{~K}$; the natural decay chains ${ }^{235} \mathrm{U},{ }^{233} \mathrm{U}$, or ${ }^{232} \mathrm{Th}$; or cosmic-ray induced radionuclides in the soil.

\section{tritium}

A radionuclide of hydrogen with a half-life of 12.3 years, which decays by emitting a low-energy beta particle.

\section{universal waste}

Hazardous wastes that are more common and pose a lower risk to people and the environment than other hazardous wastes. Some examples of universal waste are mercury thermostats, batteries, fluorescent lamps, cathode ray tubes, and consumer electronic devices. ${ }^{4}$

\section{wind rose}

Meteorological diagram that depicts the distribution of wind direction over a period of time. 
Table G-1 Prefixes used with SL (metric) units

\begin{tabular}{|lll|}
\hline \multicolumn{1}{|c}{ Prefix } & \multicolumn{1}{c}{ Factor } & Symbol \\
\hline exa & $1,000,000,000,000,000,000=10^{18}$ & $\mathrm{E}$ \\
peta & $1,000,000,000,000,000=10^{15}$ & $\mathrm{P}$ \\
tera & $1,000,000,000,000=10^{12}$ & $\mathrm{G}$ \\
giga & $1,000,000,000=10^{9}$ & $\mathrm{G}$ \\
mega & $1,000,000=10^{6}$ & $\mathrm{M}$ \\
kilo & $1,000=10^{3}$ & $\mathrm{~K}$ \\
hecto & $100=10^{2}$ & \\
deka & $10=10^{1}$ & $\mathrm{da}$ \\
deci & $0.1=10^{-1}$ & $\mathrm{~d}^{\mathrm{a}}$ \\
centi & $.01=10^{-2}$ & $\mathrm{C}^{\mathrm{a}}$ \\
milli & $0.001=10^{-3}$ & $\mathrm{~m}$ \\
micro & $0.000001=10^{-6}$ & $\mathrm{H}$ \\
nano & $0.000000001=10^{-9}$ & $\mathrm{n}$ \\
pico & $0.000000000001=10^{-12}$ & $\mathrm{p}$ \\
femto & $0.000000000000001=10^{-15}$ & $\mathrm{f}$ \\
atto & $0.000000000000000001=10^{-18}$ & $\mathrm{~A}$ \\
\hline Avoid whe pactica & & \\
\hline
\end{tabular}

${ }^{\mathrm{a}}$ Avoid where practical.
Table G-2 Conversion Factors for Selected SI (Metric) Units

\begin{tabular}{|c|c|c|}
\hline To Convert SI Unit & To U.S. Conventional Unit & Multiply By \\
\hline \multicolumn{3}{|l|}{ Area } \\
\hline square centimeters & square inches & 0.155 \\
\hline square meters & square feet & 10.764 \\
\hline square kilometers & square miles & 0.3861 \\
\hline hectares & acres & 2.471 \\
\hline \multicolumn{3}{|l|}{ Concentration } \\
\hline micrograms per gram & parts per million & 1 \\
\hline milligrams per liter & parts per million & 1 \\
\hline \multicolumn{3}{|l|}{ Length } \\
\hline centimeters & inches & 0.3937 \\
\hline meters & feet & 3.281 \\
\hline kilometers & miles & 0.6214 \\
\hline \multicolumn{3}{|l|}{ Mass } \\
\hline grams & ounces & 0.03527 \\
\hline kilograms & pounds & 2.2046 \\
\hline kilograms & ton & 0.00110 \\
\hline \multicolumn{3}{|l|}{ Pressure } \\
\hline pounds per square foot & pascal & 0.000145 \\
\hline \multicolumn{3}{|l|}{ Radiation } \\
\hline becquerel & curie & $2.7 \times 10-11$ \\
\hline becquerel & picocurie & 27.0 \\
\hline gray & $\mathrm{rad}$ & 100 \\
\hline sievert & rem & 100 \\
\hline coulomb per kilogram & roentgen & 3,876 \\
\hline \multicolumn{3}{|l|}{ Temperature } \\
\hline degrees Celsius & degrees Fahrenheit & $\begin{array}{l}1.8, \text { then add } \\
32\end{array}$ \\
\hline \multicolumn{3}{|l|}{ Velocity } \\
\hline meters per second & miles per hour & 2.237 \\
\hline \multicolumn{3}{|l|}{ Volume } \\
\hline cubic meters & cubic feet & 35.315 \\
\hline Liters & gallons & 0.2642 \\
\hline
\end{tabular}




\section{Volume I. Distribution List}

INTERNAL DISTRIBUTION

EH\&S Division

David Baskin

David Kestell

Robert Fox

Howard Hatayama

John Jelinski

Peter Lichty

Don Lucas

Dan Lunsford Ron Pauer

Nancy Rothermich

Patrick Thorson

Linnea Wahl

Steve Wyrick

88-Inch Cyclotron

Claude Lyneis

Facilities Division

Steve Black

Laura Chen

Jerry Ohearn

Jeff Philliber

Jennifer Ridgeway

Laboratory Counsel

Nancy Ware

Laboratory Library

Building 50

Building 90P

Public Affairs

Don Medley

Radiation Safety Committee

David Shuh 


\section{EXTERNAL DISTRIBUTION}

\section{Alameda County \\ Susan Hugo}

Argonne National Laboratory

Environment, Safety, and Health

Norbert Golchert

Argonne National Laboratory (West)

Nuclear Program Services

Gary Marshall

Bay Area Air Quality Management District

Jack Broadbent, Executive Officer

Berkeley Public Library

Reference Desk

Brookhaven National Laboratory

Environmental and Waste Management Services Division Karen Ratel

\section{California Department of Public Health}

Radiological Health Branch

Steve Hsu

Kent Prendergast

California Department of Toxic Substances Control

Facility Permitting Branch

Wie Wie Chiu

California Regional Water Quality Control Board,

San Francisco Bay Region

David Elias

California State Assembly, 14th District

Assemblywoman Loni Hancock
California State Senate, Senate District 09

Senate President pro tem Don Perata

\section{City of Berkeley}

Office of Emergency and Toxics Management Nabil Al-Hadithy

\section{City of Berkeley}

Community Environmental Advisory Commission Jason Kibbe, Chair

$$
\begin{aligned}
& \text { City of Oakland } \\
& \text { Leroy Griffin }
\end{aligned}
$$

Committee to Minimize Toxic Waste Gene Bernardi Pam Sihvola

\section{East Bay Municipal Utility District}

Source Control Division

Cynthia Soohoo

Fermi National Accelerator Laboratory Environment, Safety, and Health Section Bill Griffing

Idaho National Laboratory

Environmental Management Program Susan Stiger

Lawrence Livermore National Laboratory Operations and Regulatory Affairs Division Gretchen Gallegos

Los Alamos National Laboratory

Environment, Health, and Safety Division Douglas Stavert

National Renewable Energy Laboratory

Environment, Safety, and Health Maureen Jordan 
Oak Ridge National Laboratory

Operations, Environment, Safety, and Health

Kelly Beierschmitt

\section{Oakland Main Library}

Reference Desk

\section{Pacific Northwest Laboratory}

R. W. Hanf

Sandia National Laboratories, Albuquerque

Environment, Safety, and Health Stephanie Salinas

Sandia National Laboratories/California

Environmental Protection Division

Barbara Larsen

Savannah River Site (Westinghouse Savannah River Company)

Environmental Sampling and Reporting

$$
\text { James Heffner }
$$

\section{Stanford Linear Accelerator Center}

Environment, Safety and Health Division

Helen Nuckolls

United States Congress, $9^{\text {th }}$ Congressional District of California

Congresswoman Barbara Lee

United States Senate

Senator Barbara Boxer

United States Senate

Senator Dianne Feinstein

\section{U.S. Department of Energy (Berkeley Site Office)}

Lawrence Berkeley National Laboratory

Aundra Richards
U.S. Department of Energy

Oak Ridge Office

David R. Allen

U.S. Department of Energy (Headquarters)

SC-82, Bldg: GTN

Caryle Miller

U.S. Department of Energy (Headquarters)

EH-412, Bldg: FORS

Ross Natoli

U.S. Department of Energy

Office of Scientific and Technical Information

U.S. Environmental Protection Agency (Region 9)

Air and Toxics Division

Debbie Jordan

University of California, Office of the President

George Campbell

University of California at Berkeley

Lawrence Hall of Science Steve Mullin

University of California at Berkeley

Office of Radiation Safety

Greg Yuhas

University of California at Berkeley Environment, Health, and Safety Mark Freiberg

University of California at Berkeley Public Health Library

Sue Miller

University of California at San Francisco

Environment, Health, and Safety Ara Tahmassian 


\section{References}

\section{Preface}

1. U.S. Department of Energy, Environment, Safety, and Health Reporting, DOE Order 231.1A (1995, as amended).

\section{Executive Summary}

1. U.S. DOE, Environment, Safety, and Health Reporting.

2. U.S. Department of Energy, Contract Between the United States of America and the Regents of the University of Califormia, DE-AC0205CH11231 (2005).

3. U.S. Department of Energy, Occurrence Reporting and Processing of Operations Information, DOE Manual 231.1-2, (August 2003).

4. Committee on the Biological Effects of Ionizing Radiations (BEIR V), Health Effects of Exposure to Low Levels of Ionizing Radiation, National Academies Press (1990).

5. U.S. Environmental Protection Agency, National Emission Standards for Emissions of Radionuclides Other Than Radon from Department of Energy Facilities, Title 40 Code of Federal Regulations (CFR) Part 61, Subpart H (1989, as amended).

Chapter 1: Introduction

1. The National Academies' Web site:

http://www.nationalacademies.org/about (July 23, 2007). 
2. ABAG-MTC's Web site, Bay Area Census, 2000 census data. http://www.bayareacensus.ca.gov/cities/cities.htm.

3. Ernest Orlando Lawrence Berkeley National Laboratory, 2006 Long Range Development Plan (July 2007).

4. Safe Drinking Water Act, 42 USC \300f et seq. (1974, as amended).

5. Executive Order 13423 of January 24, 2007, Strengthening Federal Environmental, Energy, and Transportation Management, Federal Register, Vol. 72, No. 17, Friday, January 26, 2007, page 3919.

6. See Note 3 above.

7. Ibid.

8. Ibid.

Chapter 2: Performance-Based Environmental Management System

1. International Organization for Standardization (ISO) 14001: 2004(E), Environmental Management Systems_-Requirements with Guidance for Use, http://www.iso.org/.

2. U.S. Executive Order 13148, Greening the Government through Leadership in Environmental Management (April 22, 2000).

3. U.S. Department of Energy, Environmental Protection Program, DOE Order 450.1 (January 2005, as amended).

4. U.S. Executive Order 13423 (see Chapter 1, Note 5).
5. Ernest Orlando Lawrence Berkeley National Laboratory, PerformanceBased Environmental Management System Plan, LBNL/PUB 3180, (August 2005).

Chapter 3: Environmental Program Summary

1. Ernest Orlando Lawrence Berkeley National Laboratory, "ISM Guiding Principles," Integrated Safety Management, http://www.lbl.gov/ehs/pub811/principles.html.

2. U.S. Executive Order 13148 (See Chapter 2, Note 2).

3. U.S. DOE (see Chapter 2, Note 3).

4. International Organization for Standardization (ISO) (see Chapter 2, Note 1).

5. U.S. DOE (see Executive Summary, Note 3).

6. Clean Air Act, 42 USC $\$ 7401$ et seq. (1967, as amended).

7. Air Resources, California Health and Safety Code \$39000 et seq. (1967, as amended).

8. U.S. EPA (see Executive Summary, Note 5).

9. U.S. Department of Energy, Radiation Protection of the Public and the Environment, DOE Order 5400.5 (1990, as amended).

10. Bay Area Air Quality Management District, Permit to Operate for Lawrence Berkeley National Laboratory (Plant No. 723 and G No. 6134) (July 2007). 
11. Air Toxics "Hot Spots" Information and Assessment, California Health and Safety Code $\$ 44300$ et seq. (1987, as amended).

12. Comprehensive Environmental Response, Compensation, and Liability Act of 1980, 42 USC $\int 9601$ et seq. (1980, as amended).

13. Emergency Planning and Community Right-to-Know Act of 1986, 42 USC $\$ 11001$ et seq. (1986, as amended).

14. Hazardous Materials Release Response Plans and Inventory Law, California Health and Safety Code $\$ 25500$ et seq. (1985, as amended).

15. See Note 2 above.

16. Ernest Orlando Lawrence Berkeley National Laboratory, Hazardous Materials Business Plan, EH\&S Division (March 2007).

17. Federal Insecticide, Fungicide, and Rodenticide Act, 7 USC \$136 et seq. (1972, as amended).

18. Toxic Substances Control Act, 15 USC \$2601 et seq. (1976, as amended).

19. Resource Conservation and Recovery Act of 1976, 42 USC $\$ 6901$ et seq. (1976, as amended).

20. Hazardous Waste Control Law, California Health and Safety Code $\$ 25100$ et seq. (1972, as amended).

21. California Environmental Protection Agency, Hazardous Waste Facility Permit, EPA ID No. CA 4890008986, Department of Toxic Substances Control (December 22, 2006).

22. See Note 16 above.
23. Medical Waste Management Act, California Health and Safety Code \$\$117600-118360 (1991, as amended).

24. U.S. Department of Energy, Mixed Waste Site Treatment Plan for the Lawrence Berkeley National Laboratory (October 1995).

25. Ernest Orlando Lawrence Berkeley National Laboratory, Biennial Hazardous Waste Report for 2007, Waste Management Group.

26. Ernest Orlando Lawrence Berkeley National Laboratory, Annual Report of Waste Generation and Pollution Prevention Progress, Waste Management Group, http://www.hss.doe.gov/pp/data_entry/reports/d_wasteRpt.aspx? $C Y=2007 \& S I D=139 \& P=0 \& W=0$ (annual update).

27. See Note 24 above.

28. See Note 23 above.

29. Ernest Orlando Lawrence Berkeley National Laboratory, Corrective Measures Study Report, Environmental Restoration Program (February 2005).

30. California Department of Toxic Substances Control, Notice of Final Decision for Correction Measures Study Report and Remedy Selection for Lawrence Berkeley National Laboratory (August 31, 2005).

31. Ernest Orlando Lawrence Berkeley National Laboratory, Soil Management Plan, Environmental Restoration Program (September 2006). 
32. Ernest Orlando Lawrence Berkeley National Laboratory, Groundwater Monitoring and Measurement Plan, Environmental Restoration Program (September 2006).

33. U.S. Executive Order 13423 (see Chapter 1, Note 5).

34. Hazardous Waste Source Reduction and Management Review Act of 1989, California Health and Safety Code $\$ 25244.12$ et seq. (1989).

35. Ernest Orlando Lawrence Berkeley National Laboratory, Source Reduction Evaluation Review Plan and Plan Summary (2007).

36. Ernest Orlando Lawrence Berkeley National Laboratory, Hazardous Waste Management Report Summary, Waste Management Group (2007).

37. Pollution Prevention Act of 1990, 42 USC $\$ 13101$ et seq. (1990).

38. Clean Water Act, 33 USC \$1251 et seq. (1977, as amended).

39. California Porter-Cologne Water Quality Control Act, California Water Code $\$ 13000$ et seq. (1969, as amended).

40. East Bay Municipal Utility District, Wastewater Discharge Permit 06600791 (Sitewide) 7/8/07; 50347891 (Groundwater Treatment System) 11/7/07; 50238911 (Buildings 25 and 77 Fixed Treatment Units) 4/8/07.

41. Central Contra Costa Sanitary District, Class III Industrial User Permit for Joint Genome Institute (January 2006).

42. California State Water Resources Control Board, General Permit for Stormwater Discharges Associated With Industrial Activity No.
201I002421), Water Quality Order 97-03-DWQ, NPDES General Permit No. CAS 000001 (1997).

43. Ernest Orlando Lawrence Berkeley National Laboratory, Storm Water Pollution Prevention Plan, Environmental Services Group (March 2006).

44. Ernest Orlando Lawrence Berkeley National Laboratory, Storm Water Monitoring Program, Environmental Services Group (November 2005).

45. Ernest Orlando Lawrence Berkeley National Laboratory, 2006-2007 Annual Report for Stormwater Discharges Associated with Industrial Activity, Environmental Services Group (June 2007).

46. See Note 34 above.

47. Aboveground Petroleum Storage Act, California Health and Safety Code, $\$ 25270$ et seq. (1989, as amended).

48. Ernest Orlando Lawrence Berkeley National Laboratory, Spill Prevention, Control, and Countermeasures Plan, Environmental Services Group (October 2002).

49. Underground Storage of Hazardous Substances, California Health and Safety Code $\$ 25280$ et seq. (1983, as amended).

50. Resource Conservation and Recovery Act of 1976, Subchapter IX, Regulation of Underground Storage Tanks, 42 USC $\int 6991$ (1988, as amended).

51. Safe Drinking Water Act, 42 USC §300f et seq. (1974, as amended). 
52. National Environmental Policy Act of 1969, 42 USC \$4321 et seq. (1970, as amended).

53. California Environmental Quality Act of 1970, Public Resources Code $\$ 21000$ et seq. (1970, as amended).

54. Federal Endangered Species Act of 1973, 16 USC \$1531 et seq. (1973, as amended).

55. California Endangered Species Act, Fish and Game Code \$2050 et seq. (1985, as amended).

56. National Historic Preservation Act of 1966, 16 USC \$470 et seq. (1966, as amended).

57. Migratory Bird Treaty Act, 16 USC $\$ 703$ (Supp. I 1989) (1918, as amended).

\section{Chapter 4: Environmental Monitoring}

1. Ernest Orlando Lawrence Berkeley National Laboratory, Environmental Monitoring Plan, Environmental Services Group (February 2006).

2. U.S. EPA, National Emission Standards (see Executive Summary, Note 5).

3. U.S. DOE, Radiation Protection of the Public and the Environment (see Chapter 3, Note 9).

4. See Note 3 above.

5. Ibid.
6. California SWRCB, General Permit (see Chapter 3, Note 42).

7. U.S. Environmental Protection Agency, National Primary Drinking Water Standards, 40 CFR 141, Subpart B (1976, as amended).

8. California Department of Health Services, Domestic Water Quality and Monitoring Regulations, Title 22 California Code of Regulations (CCR) §64443 (1984, as amended).

9. See Note 7 above.

10. See Note 8 above.

11. California Regional Water Quality Control Board, San Francisco Bay Region Basin Plan, Chapter 3 (January 2007),

www.waterboards.ca.gov/sanfranciscobay.basin_planning.shtml.

12. See Note 11 above.

13. Berkeley Laboratory, Storm Water Monitoring Program (see Chapter 3, Note 44).

14. East Bay Municipal Utility District, W astewater Discharge Permits (see Chapter 3, Note 40).

15. See Note 3 above.

16. U.S. Department of Energy, Environmental Regulatory Guide for Radiological Effluent Monitoring and Environmental Surveillance, DOE/EH-0173T (January 1991).

17. California Department of Health Services, Standards for Protecting Against Radiation, 17 CCR $\$ 30253$ (1994, as amended). 
18. See Note 14 above.

19. U.S. Nuclear Regulatory Commission, Standards for Protection Against Radiation, 10 CFR 20, Subpart K (1994, as amended).

20. See Note 19 above.

21. See Note 17 above.

22. See Note 14 above.

23. EBMUD, Wastewater Discharge Permit (Account No. 50347891) (see Note 14 above).

24. See Note 7 above.

25. Ernest Orlando Berkeley National Laboratory, Analysis of Background Distributions of Inorganic Elements in the Groundwater at Lawrence Berkeley National Laboratory, Environmental Restoration Program (July 2002).

26. See Note 7 above.

27. See Note 8 above.

28. See Note 23 above.

29. Ernest Orlando Lawrence Berkeley National Laboratory, Analysis of Background Distributions of Metals in the Soil at Lawrence Berkeley National Laboratory, Environmental Restoration Program (June 2002).

30. Ibid.

\section{Chapter 5: Radiological Dose Assessment}

1. U.S. EPA, National Emission Standards (see Executive Summary, Note 5).

2. See Note 1 above.

3. U.S. Environmental Protection Agency, National Emissions Standards for Hazardous Air Pollutants (Radionuclides), Availability of Updated Compliance Model, Federal Register, Vol. 71, No. 34, p. 8854 (February 21, 2006).

4. U.S. DOE, Radiation Protection of the Public and the Environment (see Chapter 3, Note 9).

5. See Note 1 above.

6. Dobson, J.E., and E. A. Bright, Landscan Global Population 1998 Database,

http://www.ornl.gov/gist/projects/LandScan/landscandoc.htm (August 2002).

7. Committee on the Biological Effects of Ionizing Radiations (BEIR V) (see Executive Summary, Note 4).

8. See Note 4 above.

9. Mauro, J., and N. M. Briggs, Assessment of Variations in Radiation Exposure in the United States, U.S. Environmental Protection Agency (2005).

10. See Note 4 above. 
11. U.S. Department of Energy, A Graded Approach for Evaluating Radiation Doses to Aquatic and Terrestrial Biota, DOE Technical Standard DOE-STD-1153-2002 (August 2002).

12. U.S. Department of Energy, RESRAD-BIOTA for Windows, Version 1.0, developed at the Environmental Assessment Division of Argonne National Laboratory for the U.S. Department of Energy, with support from the U.S. Environmental Protection Agency and the U.S. Nuclear Regulatory Commission, www.ead.anl.gov/resrad (September 30, 2003).

13. Ibid.

\section{Chapter 6: Quality Assurance}

1. Ernest Orlando Lawrence Berkeley National Laboratory, Operating and Quality Management Plan, LBNL/PUB-3111, Revision 8 (March 2007).

2. Berkeley Laboratory, Environmental Monitoring Plan (see Chapter 4, Note 1).

3. U.S. DOE, Environmental Regulatory Guide (see Chapter 4, Note 16).

4. U.S. EPA, National Emission Standard (see Executive Summary, Note 5).

5. Lawrence Livermore National Laboratory/Lawrence Berkeley National Laboratory, Quality Assurance and Quality Control Plan for Analytical Services (February 2004).

6. U.S. Department of Energy, ES\&H Operational Awareness Guide, Berkeley Site Office (January 1998).

\section{Glossary}

1. Agency for Toxic Substances and Disease Registry, ATSDR Glossary of Terms (June 21, 2004). http:/ /www.atsdr.cdc.gov/glossary.html.

2. Ibid.

3. Shlein, Bernard, Lester A. Slaback, Jr., and Brian Kent Birdy, editors, Handbook of Health Physics and Radiological Health (Lippincott Williams and Wilkins, 1998).

4. California Department of Toxic Substances Control, Managing Universal Waste in California, Fact Sheet, (June 2003). 
This work was supported by the Director, Office of Science, U.S. Department of Energy under Contract Number DE-AC02-05CH11231 